Aus der Abteilung Medizinische Mikrobiologie

(Prof. Dr. med. U. Groß)

im Zentrum Hygiene und Humangenetik

der Medizinischen Fakultät der Universität Göttingen

\title{
Zur Bedeutung von Plasmiden für die Pathogenität von Campylobacter jejuni
}

\author{
Inaugural-Dissertation \\ zur Erlangung des Doktorgrades \\ der Medizinischen Fakultät \\ der \\ Georg-August-Universität zu Göttingen \\ vorgelegt von \\ Sebastian Burghard \\ aus \\ Bad Salzungen
}

Göttingen 2012 
Dekan: Prof. Dr. Michael P. Schön

I. Berichterstatter: Prof. Dr. U. Groß

II. Berichterstatter: Prof. Dr. S. Pöhlmann

Tag der mündlichen Prüfung: 20.11.2012 

Diese Arbeit ist in Liebe und Dankbarkeit meinen Eltern gewidmet. 



\section{Inhalt}

1. EINLEITUNG UND THEORETISCHE GRUNDLAGEN .......................................... 1

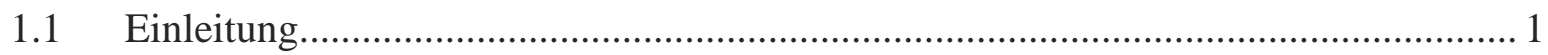

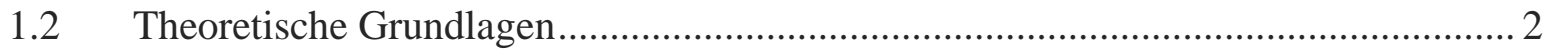

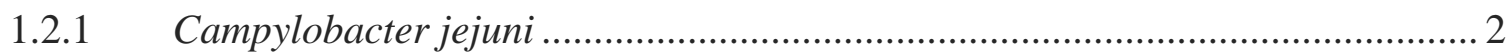

1.2.1.1 Morphologie, Physiologie und Kulturbedingungen................................2

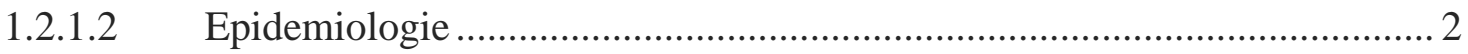

1.2.1.3 Campylobakteriose ....................................................................... 4

1.2.1.4 Sekundärerkrankungen nach Campylobacter-assoziierter Infektion ........... 4

1.2.2 Humane intestinale Caco2-Zellen .............................................................. 6

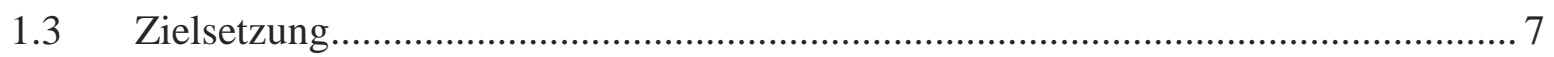

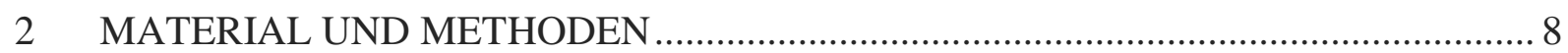

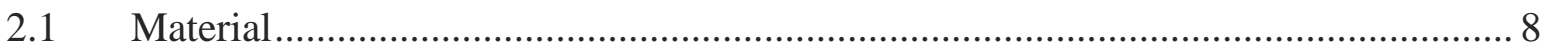

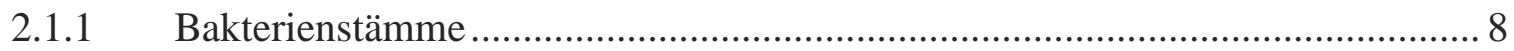

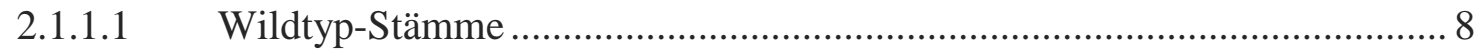

2.1.1.2 Transkonjugierte Varianten klinischer Isolate von $C$. jejuni ...................... 8

2.1.1.3 Andere verwendete Bakterienstämme.............................................. 9

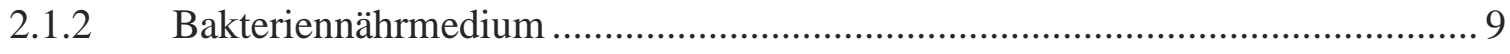

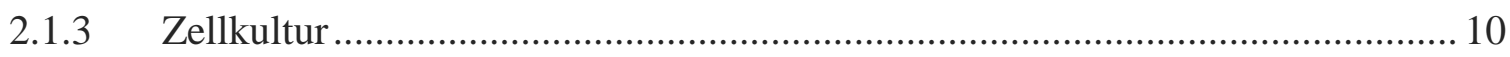

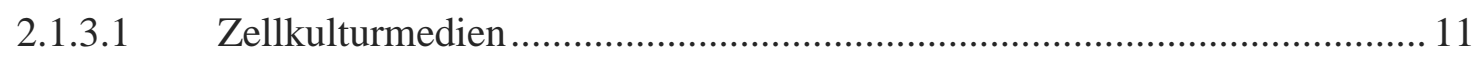

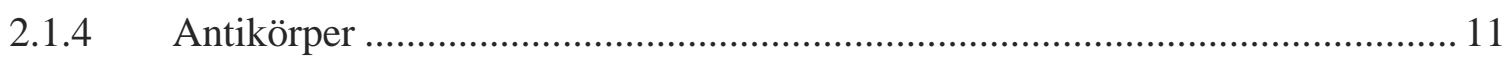

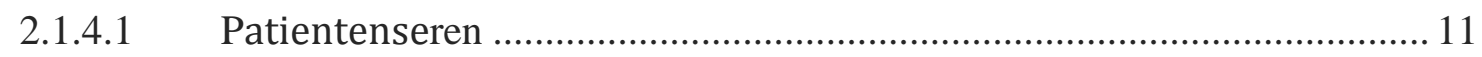

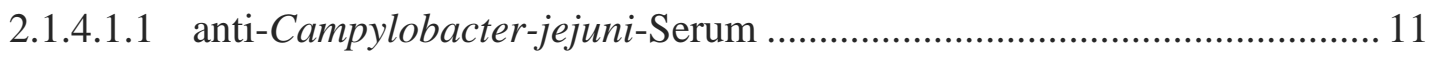

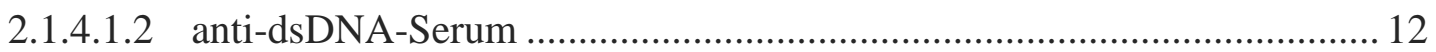

2.1.4.2 Zytochromkonjugierte Sekundärantikörper ........................................ 12

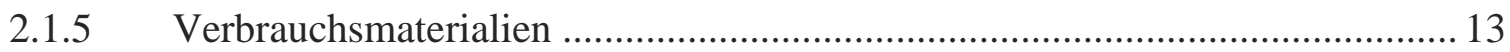




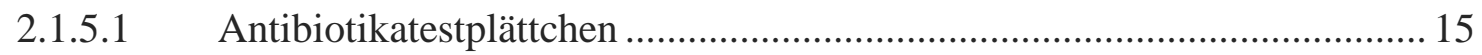

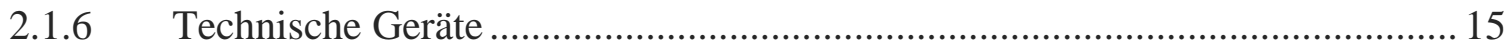

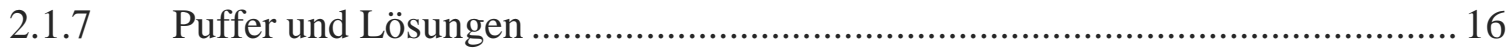

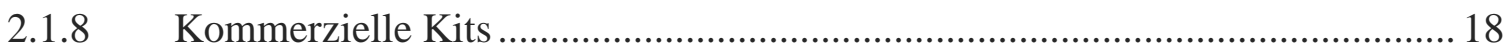

2.1.8.1 Pulsfeldgelelektrophorese (PFGE)-Kit-Komponenten ........................... 18

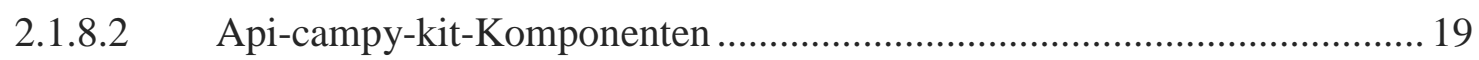

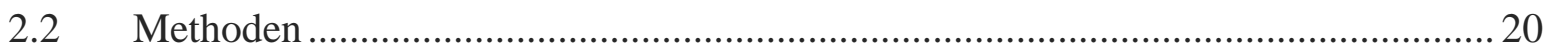

2.2.1 Isolierung, Identifizierung und biochemische Charakterisierung klinischer Campylobacter-jejuni- Isolate einschließlich Erstellung qualitativer

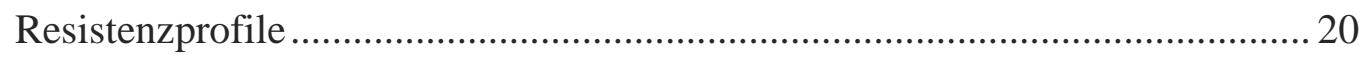

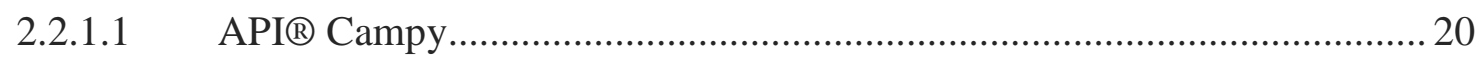

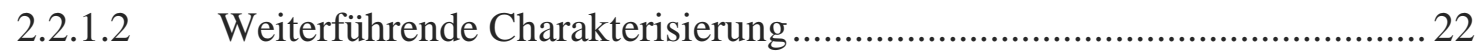

2.2.2 Bestimmung des log-Phasen-Wachstums von C.jejuni-Isolaten unter standardisierten Bedingungen .............................................................. 23

2.2.3 Kultivierung und Subkultivierung von humanen Caco2-Zellen ...................... 23

2.2.3.1 Auftauen der Zellen ......................................................................... 23

2.2.3.2 Ernte der Caco2-Zellen zur weiteren Subkultivierung ..............................2 24

2.2.3.3 Beschichtung von Glasdeckplättchen mit einem biologischen Oberflächenpolymer zur Optimierung der Adhärenzeigenschaften der Caco2-Zellen

2.2.3.4 Aussaat der Caco2-Zellen auf oberflächenveränderte Glasdeckplättchen.. 25

2.2.4 Genetische Manipulation der Bakterienstämme ......................................... 25

2.2.4.1 Plasmidheilung tetrazyklinresistenter C. jejuni-Isolate ...........................225

2.2.4.2 Selektion tetrazyklinsensibler Klone mit der Replica-plating-Methode..... 26

2.2.4.3 Alkali-Lysis-Prozedur zur Präparation von bakteriellen Plasmiden.......... 27

2.2.4.4 Erzeugung isogener Varianten durch konjugativen Plasmidtransfer......... 27

2.2.4.5 Qualitativer Nachweis der Plasmidakquirierung der Rezipientenstämme durch Plasmid-mini-Präparation 28 
2.2.4.6 Pulsfeldgelelektrophorese (PFGE) von Donor- und Rezipientenstämmen sowie der erzeugten isogenen Varianten............................................... 28

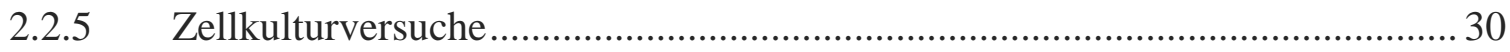

2.2.5.1 Kulturelle Methode mit Hilfe des Gentamicin-Protektions-Assays (GPA)... 30

2.2.5.2 Indirekte Doppelimmunfluoreszenz zur differenzierten Darstellung intraund extrazellulärer Bakterien in infizierten Caco2-Zellmonolayern

2.2.5.3 Präadsorption des Patientenserums gegen paraformaldehydfixierte Caco2Zellen

2.2.5.4 Status der Zellmembranintegrität humaner Caco2-Zellen nach der Fixierung mit $4 \%$ - iger Paraformaldehydlösung

2.2.5.5 Infektion humaner Caco2-Zellen mit mid-log-Phasen-C. jejuni-Kulturen 32

2.2.5.6 Bestimmung der Adhärenz und Invasion durch differenzierte Antikörperreaktionen

2.2.5.7 Bestimmung der Invasions- und Zellassoziationsraten durch fluoreszenzmikroskopische Auswertung

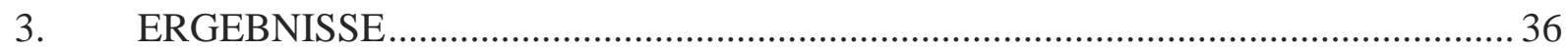

3.1 Charakterisierung ausgewählter klinischer Isolate von $C$. jejuni ........................... 36

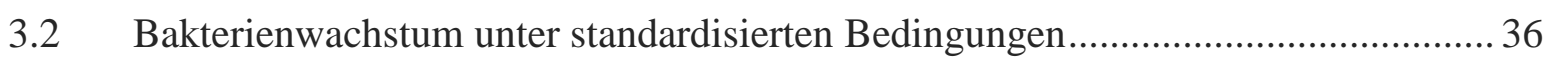

3.3 Genetische Manipulation der Bakterienstämme................................................. 38

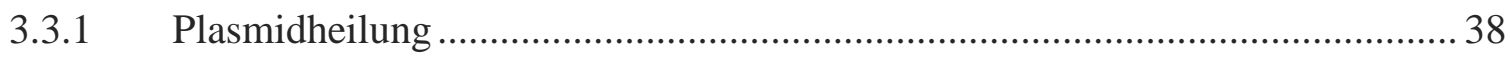

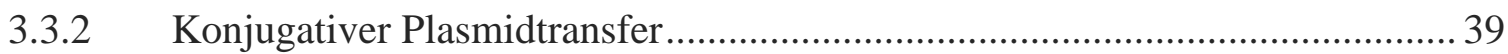

3.3.2.1 Pulsfeldgelelektrophorese der Wildtypstämme und der Transkonjuganten ..

3.4 Zustand der Zellmembranintegrität von humanen Caco2-Zellen nach Fixierung mit

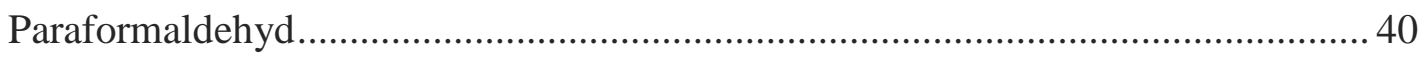

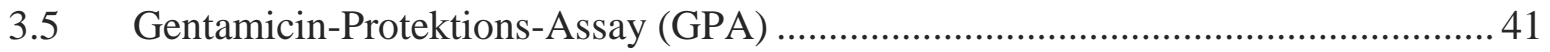




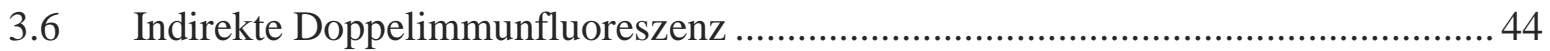

3.7 Adhärenz und Invasion der Wildtypstämme von $C$. jejuni und ihrer

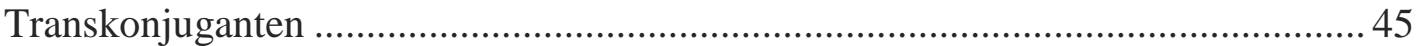

3.8 Adhärenz und Invasion der Kontrollbakterien ................................................ 49

3.9 Zeitlicher Verlauf von Adhärenz und Invasion ...............................................5 52

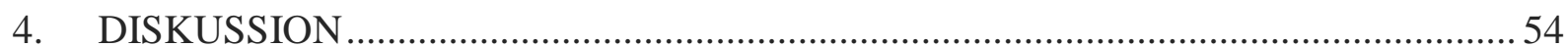

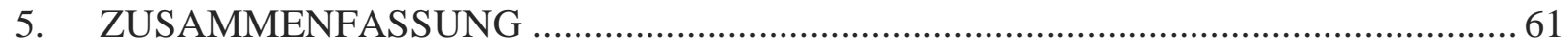

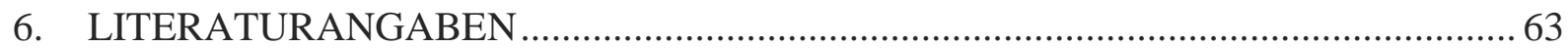

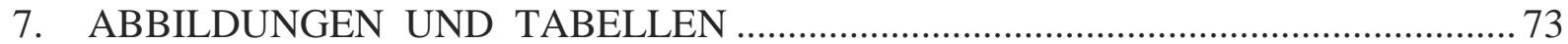

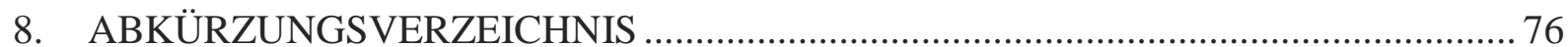




\section{EINLEITUNG UND THEORETISCHE GRUNDLAGEN}

\section{1 $\quad$ Einleitung}

Als Ursache für bakteriell hervorgerufene gastrointestinale Infektionen kommt der Bakterienspezies Campylobacter jejuni (C. jejuni) in Deutschland und weltweit eine herausragende medizinische Bedeutung zu. Bakterien der Gattung Campylobacter und unter ihnen hauptsächlich die Spezies C. jejuni sind neben Salmonellosen die Hauptursache bakteriell verursachter Enteritiden (Altekruse et al. 1999). Infektionen mit Bakterien der Gattung Campylobacter wurden erstmals 2001 mit der Einführung des Infektionsschutzgesetzes (IfSG) bundesweit meldepflichtig (RKI 2002).

Obwohl die relativ blande verlaufende Campylobakteriose herkömmlichen Therapiestrategien gut zugänglich ist, erwachsen bei Patienten mit komplizierten oder protrahierten Verläufeninsbesondere mit Komplikationen, wie dem Guillain-Barré-Syndrom (GBS), dem MillerFisher-Syndrom (MFS) oder der aseptischen reaktiven Arthritis (Morbus Reiter)- erhebliche medizinische und gesundheitliche Konsequenzen. Darüber hinaus sei hier der volkswirtschaftliche Schaden erwähnt, der durch infektiöse Darmerkrankungen im Allgemeinen und durch $C$. jejuni-Enteritiden im Speziellen jährlich in Deutschland und weltweit verursacht wird. Nach Berechnungen des statistischen Bundesamtes wurden allein in Deutschland 2008 etwa 512 Millionen Euro für die Behandlungen infektiöser Darmerkrankungen ausgegeben (Statistisches Bundesamt 2012). Hinzu kommen Kosten für Arbeitszeitausfälle, Betreuung von kranken Familienmitgliedern etc.

Man schätzt die jährlich in den USA durch Campylobacter jejuni hervorgerufenen Gesundheitskosten auf 1,3 bis 6,2 Milliarden US\$. Zählt man die Kosten, verursacht durch Campylobacter-assoziierte GBS-Fälle hinzu, sind jährliche Ausgaben von bis zu 8 Milliarden US\$ auf Infektionen mit Campylobacter zurückzuführen (Buzby et al. 1997). Für die Länder der EU werden die jährlichen Kosten auf 2,4 Milliarden Euro geschätzt (EFSA 2011). 


\subsection{Theoretische Grundlagen}

\subsubsection{Campylobacter jejuni}

1.2.1.1 Morphologie, Physiologie und Kulturbedingungen

Campylobacter jejuni ist ein spiralig gewundenes, gramnegatives Bakterium mit einer Länge von 1,5-6 $\mu \mathrm{m}$ und einer Breite von 0,2-0,5 $\mu \mathrm{m}$. Die uni- bis bipolare monotriche Begeißelung sowie die Spiralform des Bakteriums tragen wesentlich zur intraintestinalen Motilität bei (Ketley 1997). Campylobacter jejuni wächst als mikroaerophiler und thermophiler Mikroorganismus bei einer $\mathrm{O}_{2}$-Konzentration von 3-15\% und einer $\mathrm{CO}_{2}$-Konzentration von 3$5 \%$, sowie einem Temperaturoptimum von $42{ }^{\circ} \mathrm{C}$. Diese Kulturbedingungen lassen sich auf seine natürliche Umgebung im Gastrointestinaltrakt von Warmblütern und Vögeln (Ketley 1997) zurückführen.

Das mit einer Größe von 1,6-1,7 Mbp relativ kleine Genom kann als mögliche Ursache für die anspruchsvollen Wachstumskonditionen für Bakterien der Gattung Campylobacter gedeutet werden, die sich in der fehlenden Möglichkeit zur Kohlenstofffermentation und Degradation komplexer Substanzen widerspiegelt (Taylor 1992). Extrachromosomale DNA wurde in Form von konjugativen Plasmiden und Bakteriophagen gefunden (Owen und Leaper 1981).

\subsubsection{Epidemiologie}

Als wichtigste Erregerquelle dieser weltweit verbreiteten Zoonose müssen tierische Lebensmittel wie Fleischprodukte, insbesondere Hühnerfleisch, aber auch Rohmilch angesehen werden. Ebenso ist eine Übertragung durch kontaminiertes Wasser möglich. Nach einem von Robinson durchgeführten Selbstversuch beträgt die zum Auslösen einer symptomatischen Campylobakteriose notwendige Bakterienmenge 5-800 KBE (Robinson 1981). Damit ist die Anzahl an Keimen geringer als die für die Salmonellose notwendige Infektionsdosis. 


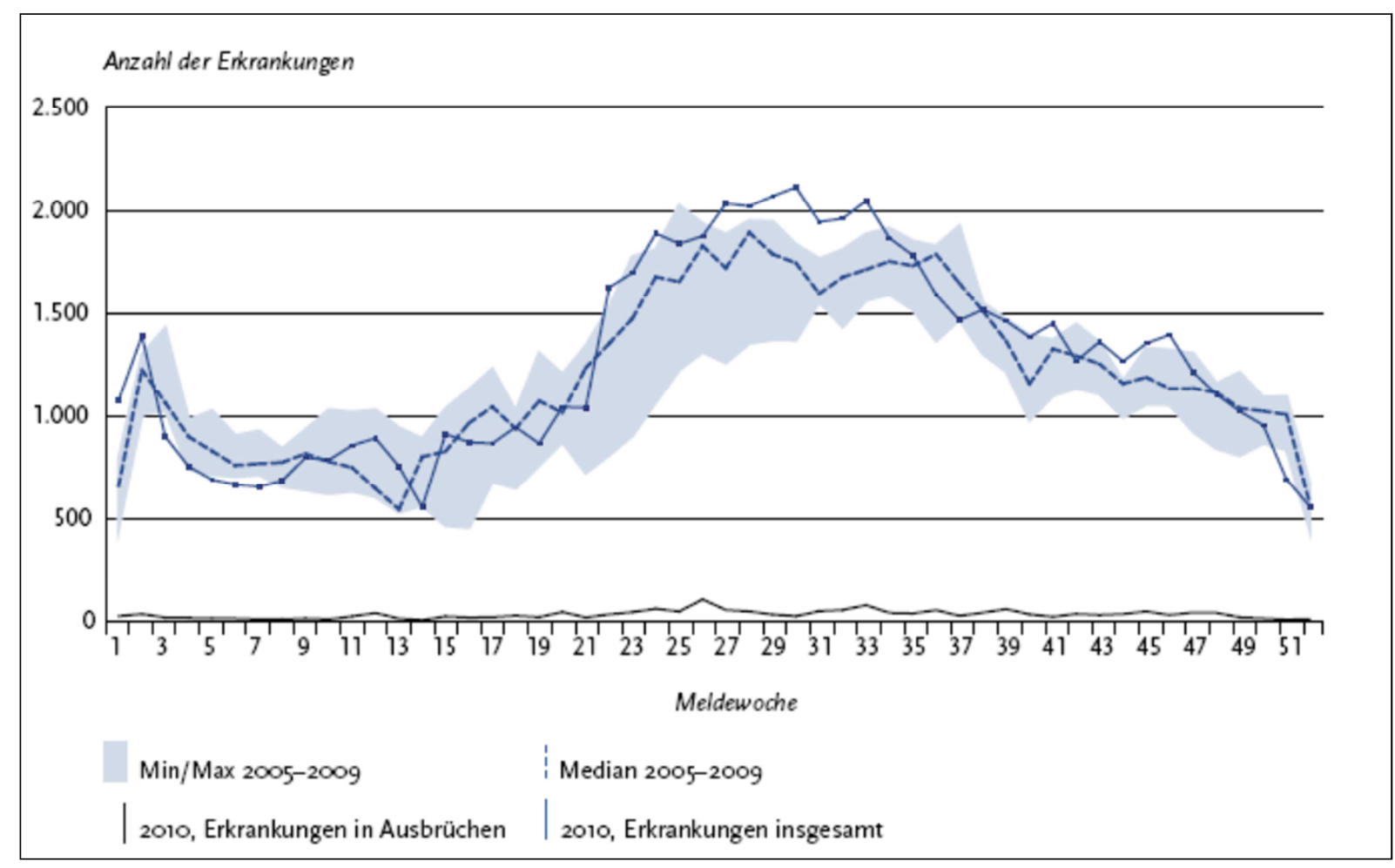

Abbildung 1: Dem RKI übermittelte Campylobacter-Enteritiden nach Meldewoche im Vergleich mit dem Median der Vorjahre und Anzahl der Erkrankungen in Häufungen nach Meldewoche für Deutschland 2010

Mit im Jahr 201065.714 gemeldeten Fällen stellen Bakterien der Gattung Campylobacter noch vor Salmonellen die häufigste bakterielle Ursache für infektiöse Enteritiden in Deutschland dar. Den mit 68\% dieser Krankheitsfälle größten Anteil hatte die Spezies Campylobacter jejuni. In der jahreszeitlichen Verteilung der Krankheitshäufigkeit zeigt sich eine erhöhte Inzidenz im II. und III. Quartal des Jahres. Demographische Untersuchungen zeigen die höchsten altersspezifischen Inzidenzraten bei einjährigen Kindern (146,6 Erkrankungen/100.000 Einwohner) sowie in der Altersgruppe der 20-24jährigen (138,8/100.000Einwohner) auf. Diese zweigipflige Zuordnung ist typisch und wird auch aus anderen europäischen Ländern gemeldet. Die geographische Verteilung unterliegt deutschlandweit zum Teil erheblichen Schwankungen unter den einzelnen Bundesländern und weist dabei ein typisches Nord-Südgefälle auf. Insgesamt ist in den letzten Jahren eine stetige Steigerung der Inzidenzzahlen zu beobachten (RKI 2011). 


\subsubsection{Campylobakteriose}

Die Campylobakteriose als klinisch fassbares Korrelat einer manifesten Infektion mit Bakterien der Gattung Campylobacter äußert sich bei den betroffenen Patienten nach einer Inkubationszeit von 2-7 Tagen durch das typische Krankheitsbild einer akuten Enteritis (Grifith und Park 1990). 12-24 h vor Auftreten der enterischen Symptomatik treten typische Prodromi wie Fieber (bis $40^{\circ} \mathrm{C}$ ) Kopfschmerzen, Myalgien und Kephalgien auf. Später kommen Abdominalschmerzen und breiig bis wässrige, in seltenen Fällen auch blutige Durchfälle hinzu (Butzler und Skirrow 1979, Walker et al. 1986, Skirrow 1977). Dabei kann zwischen zwei klinischen Erscheinungsbildern differenziert werden. Patienten in den industrialisierten Länder zeigen häufiger einen inflammatorisch dominierten Verlauf mit Blut, Schleimbeimengungen und Leukozyten im Stuhl sowie sigmoidoskopisch nachweisbare morphologische Schleimhautveränderungen, wie Schleimhautödeme und hyperäme Reaktionen. In Entwicklungsländern dominieren dagegen eher durch wässrige Durchfälle ohne morphologische Schleimhautveränderungen gekennzeichnete Verlaufsformen das Bild der akuten Campylobakteriose.

Die Diagnosestellung erfolgt mittels Erregernachweis aus frischen Stuhlkulturen, ein Antigennachweis mittels ELISA oder PCR ist ergänzend möglich. In der Regel ist der Krankheitsverlauf selbstlimitierend und bedarf lediglich einer symptomatischen Behandlung mit Volumen- und Elektrolytsubstitution. Bei schweren klinischen Verlaufsformen ist eine gezielte antibiotische Therapie mit Erythromycin oder Chinolonen angezeigt (RKI 2005).

\subsubsection{Sekundärerkrankungen nach Campylobacter-assoziierter Infektion}

Neben der akuten Infektion mit Bakterien der Gattung Campylobacter in Form von Durchfallerkrankungen existiert eine Reihe von Folgeerkrankungen, welche mit einer meist vorausgegangenen Infektion assoziiert sein können (Kaldor und Speed 1984, Ebright und Ryan 1984). Von diesen sollen hier exemplarisch das Guillain-Barré-Syndrom und der Morbus Reiter in kurzer Darstellung Erwähnung finden. 


\section{Guillan-Barré-Syndrom}

Als seltene, jedoch schwerwiegende Komplikation einer Campylobakteriose sind das Guillain-Barré-Syndrom (GBS) und das damit verwandte Miller-Fisher-Syndrom (MFS) zu nennen. Der erste Hinweis auf einen Zusammenhang zwischen einer CampylobacterInfektion und dem Auftreten eines GBS ergab sich aus einem klinischen Fall des Jahres 1982, als ein 45- jähriger Patient zwei Wochen nach gastrointestinaler Erkrankung, hervorgerufen durch Campylobacter, ein schweres GBS entwickelte (Rhodes 1982). Seit der erfolgreichen Eradikation des Poliomyelitiserregers in weiten Teilen der Welt ist das GBS zur wichtigsten Ursache einer akut auftretenden schlaffen Lähmung der quergestreiften Muskulatur geworden (Van Doorn et al. 2008). Das postinfektiös auftretende GBS ist gekennzeichnet durch eine meist symmetrisch angeordnete schlaffe Lähmung zunächst der unteren Extremitäten, Parästhesien, Reflexabschwächungen bis zur Areflexie, welche innerhalb von Tagen zur Tetraplegie fortschreiten kann. Bedingt durch eine Beteiligung der respiratorischen Muskulatur kann es in bis zu 20\% der Erkrankungsfälle zu einer Beatmungspflichtigkeit der Patienten kommen (Rantala 1991). Obwohl der Krankheitsverlauf selbstlimitierenden Charakter zeigt und in der Mehrzahl der Fälle für die Betroffenen folgenlos ausheilt, bleiben bei $15-20 \%$ der Erkrankten schwerwiegende dauerhafte neurologische Defizite zurück. Die Mortalität des GBS liegt trotz intensivmedizinischer Maßnahmen bei 2-12\%. (Alshekhlee et al. 2008, Netto et al. 2011). Das Risiko, in Zusammenhang mit einer Campylobacteriose ein GBS zu entwickeln, wird auf 2/10.000 geschätzt (Ternhag et al. 2008).

Aseptische Arthritis der großen Gelenke und das Reiter-Syndrom

Die reaktive Arthritis im Rahmen des Reiter-Syndroms ist die häufigste Form der aseptischen Polyarthritis bei jungen Männern. Das Syndrom wurde erstmals 1916 während des 1.Weltkrieges in dieser Form als Arthritis bei Soldaten, welche sich in der Rekonvaleszenzphase nach einer Durchfallerkrankung befanden, beschrieben. Die klassische Symptomentrias besteht aus Arthritis, Urethritis und Konjunktivitis. Obwohl typischerweise Chlamydia-trachomatis-Infektionen ätiologisch in Zusammenhang mit der Erkrankung gebracht werden können, verursachen auch darmpathogene Keime, unter ihnen Campylobacter jejuni, diese Krankheitsentität. Die Inzidenz wird auf 1-5\% der mit 
Campylobacter Infizierten geschätzt (Pope et al 2007). Pathogenetisch spielen wahrscheinlich Kreuzreaktionen zwischen Peptiden des HLA-B27-Antigens (Humanes Leukozyten-Antigen) und Proteinen der gramnegativen Mikroorganismen eine entscheidende Rolle (Barth und Segal 1999).

\subsubsection{Humane intestinale Caco2-Zellen}

Aufgrund des klinischen Erscheinungsbildes einer Campylobakteriose mit zum Teil blutigen Durchfällen und einer gelegentlich zu beobachtenden Bakteriämie im Krankheitsverlauf kann angenommen werden, dass Adhärenz und Invasion des Erregers in die intestinale Mukosa wesentliche Teilaspekte des pathobiologischen Mechanismus während der Infektion sind (Everest et al. 1992). Zur genauen Aufklärung der Vorgänge während einer Infektion ist daher ein geeignetes Zellkulturmodell unentbehrlich. Die in dieser Arbeit benutzte Caco2-Zelllinie wurde ursprünglich aus dem primären Kolonadenokarzinom eines 74 Jahre alten Mannes isoliert. Der Chromosomensatz dieser sehr langsam wachsenden Zelllinie mit einer Verdopplungszeit von etwa $48 \mathrm{~h}$ ist hypertetraploid.

In der Vergangenheit durchgeführte mikroskopische Untersuchungen, sowie die Messung von Enzymaktivitäten der Alkalischen Phosphatase, Sucrase-Isomaltase und Aminopeptidase deuten auf eine strukturelle wie funktionelle Polarisierung von ausdifferenzierten Caco2Zellen hin. Im Hinblick auf die gemessenen Enzymaktivitäten bestehen dabei Ähnlichkeiten mit humaner Dünndarmmukosa. An ausdifferenzierten Caco2-Zellen konnten sowohl durch elektronenmikroskopische Beurteilung als auch durch entsprechende Antikörperreaktionen Bürstensaummikrovilli an der apikalen Zelloberfläche nachgewiesen werden (Pinto et al. 1983). Dabei blieb jedoch der Grund für die metaplastische Transformation der ursprünglich aus Kolon-Schleimhaut generierten Zellen hin zu Enterozyten weiter unklar. Die hervorragende Eignung dieser Zelllinie für in- vitro-Untersuchungen bleibt jedoch aufgrund der Ähnlichkeit zu ausgereiften humanen Enterozyten unbestritten (Everest et al. 1992, Pinto et al. 1983). 


\subsection{Zielsetzung}

Obwohl in den vergangenen Jahren zunehmend Fortschritte in der molekulargenetischen und zellbiologischen Forschung auf diesem Gebiet erzielt wurden, fehlen weiterhin grundlegende Erklärungsmodelle für den Pathogenitätsmechanismus Campylobacter-assoziierter Infektionen. In der vorliegenden Arbeit sollten unter Zuhilfenahme eines Caco2Zellkulturmodells weiterführende Untersuchungen hinsichtlich der Invasions- und Adhärenzeigenschaften von klinischen $C$. jejuni-Isolaten durchgeführt werden. Dabei sollte in Anlehnung an die Kenntnis plasmidkodierter Virulenzfaktoren anderer darmpathogener Bakterienspezies (siehe Tabelle 1) die Bedeutung von Plasmiden für die Expression von Virulenzfaktoren von $C$. jejuni, vor allem im Hinblick auf Zellinvasion und -adhärenz, geklärt werden. Ziel war es dabei, klinische Isolate von $C$. jejuni $\mathrm{zu}$ isolieren, weiterführend $\mathrm{zu}$ charakterisieren und das Vorkommen von Plasmid-DNA zu erfassen. Durch die Erzeugung isogener Varianten und den in-vitro-Vergleich von Bakterienstämmen, welche sich ausschließlich durch den Besitz von Plasmid-DNA unterscheiden, sollten Unterschiede hinsichtlich der Adhärenz- und Invasionseigenschaften als Maß für die Pathogenität aufgedeckt werden. Um den zeitlichen Verlauf der Invasion näher zu charakterisieren, sollten invasionskinetische Modellversuche etabliert und durchgeführt werden.

\begin{tabular}{|l|l|l|}
\hline Virulenzfaktor & Bakterienspezies & Art des Virulenzfaktors \\
\hline Enterotoxin & E. coli & Toxin \\
\hline Tetanustoxin & C. tetani & Toxin \\
\hline $\begin{array}{l}\text { YOP(yersinia-outer-membrane } \\
\text { protein) }\end{array}$ & Yersinia spp & Invasin \\
\hline IPA (invasion-plasmid-antigen) & Shigella spp. & Invasin \\
\hline SVP (salmonella-virulence-plasmid) & Salmonella spp. & Invasin \\
\hline CFA (colonization-factor-antigen) & E. coli & Adhäsin \\
\hline
\end{tabular}

Tabelle 1: Beispiele für plasmidkodierte Virulenzfaktoren anderer darmpathogener Bakterienspezies. 


\subsubsection{Wildtyp-Stämme}

Die verwendeten Bakterienstämme sind klinische Isolate von Patienten aus dem Klinikum Göttingen bzw. aus peripheren Krankenhäusern der Göttinger Umgebung. Alle Isolate stammen aus dem Jahr 2000; bei ihnen geht der fortlaufenden Nummerierung die Kennzeichnung A voraus. Isolierte Plasmide eines Stammes wurden mit [pCj Stammname] bezeichnet. Insgesamt konnten von symptomatischen Patienten mit blutiger oder wässriger Diarrhoe 56 verschiedene Stämme von C. jejuni isoliert werden, von denen 29\% ein Plasmid besaßen.

\subsubsection{Transkonjugierte Varianten klinischer Isolate von C. jejuni}

Die hergestellten Konjuganten tragen den Namen des Rezipienten gefolgt vom Namen des Plasmids des Donorstammes.

\begin{tabular}{|c|c|c|c|c|c|}
\hline Rezipient & Phänotyp & Donor & Phänotyp & Transkonjugant & Phänotyp \\
\hline A34 & $\mathrm{Nal}_{\mathrm{res}}$ & A9 & Tet $_{\text {res }}$ & A34/pCjA9 & $\mathrm{Nal}_{\text {res }} / \mathrm{Tet}_{\text {res }}$ \\
\hline A34 & $\mathrm{Nal}_{\text {res }}$ & A13 & Tet $_{\text {res }}$ & A34/pCjA13 & $\mathrm{Nal}_{\text {res }} / \mathrm{Tet}_{\mathrm{res}}$ \\
\hline A 22 & $\mathrm{Nal}_{\text {res }}$ & A9 & Tet $_{\text {res }}$ & A22/pCjA9 & $\mathrm{Nal}_{\text {res }} / \mathrm{Tet}_{\mathrm{res}}$ \\
\hline A 22 & $\mathrm{Nal}_{\mathrm{res}}$ & A13 & Tet $_{\text {res }}$ & $\mathrm{A} 22 / \mathrm{pCjA} 13$ & $\mathrm{Nal}_{\text {res }} / \mathrm{Tet}_{\mathrm{res}}$ \\
\hline A3 & $\mathrm{Nal}_{\text {res }}$ & A9 & Tet $_{\text {res }}$ & $\mathrm{A} 3 / \mathrm{pCj} \mathrm{A} 9$ & $\mathrm{Nal}_{\text {res }} / \mathrm{Tet}_{\mathrm{res}}$ \\
\hline A3 & $\mathrm{Nal}_{\mathrm{res}}$ & A13 & Tet $_{\text {res }}$ & A3/pCjA13 & $\mathrm{Nal}_{\text {res }} / \mathrm{Tet}_{\mathrm{res}}$ \\
\hline
\end{tabular}

Tabelle 2: Zusammenstellung der erzeugten transkonjugierten Varianten. 
2.1.1.3 Andere verwendete Bakterienstämme

C. jejuni Laborstamm NCTC 81-176

Julian Ketley, University of Leicester, GB

Salmonella enterica serovar Typhimurium

Manassas, VA, USA

(ATCC 14028)

E. coli DH-5 $\alpha$

Invitrogen, Karlsruhe

HS-1 Hühnerisolat

B-66 bovines Isolat

Die Isolate HS-1 und B-66 wurden uns freundlicherweise von Dr. R. Schmitt-Ott, Universität Göttingen, zur Verfügung gestellt.

2.1.2 Bakteriennährmedium

Alle verwendeten Agar-Ansätze sowie die Brain-Heart-Infusion (BHI) wurden in der institutseigenen Nährbodenküche hergestellt und auf Sterilität überprüft.

Columbia-Blut-Agar (BA) in folgender Zusammensetzung:

$23 \mathrm{~g} / \mathrm{l} \quad$ Spezialnährsubstrat

$1,0 \quad \mathrm{~g} / 1 \quad$ Stärke

$5,0 \quad \mathrm{~g} / \mathrm{l} \quad \mathrm{NaCl}$

13,0 g/l Agar-Agar

supplementiert mit $7 \%$ Schafblut

$\underline{\text { Tetrazyklin-Agar }}$

Columbia-BA in oben angegebener Zusammensetzung, supplementiert mit $20 \mu \mathrm{g} / \mathrm{ml}$ Tetrazyklin. 


\section{Campylobacter-Flüssignährmedium (für 500ml)}

1 Einheit Campylobacter-Anreicherungssupplement Oxoid,Wesel

$25 \mathrm{ml}$ lysiertes Pferdeblut $\quad$ Oxoid

Brain-Heart-Infusion (BHI) -Flüssignährmedium zur Bakterienkultivierung in folgender Zusammensetzung:

$\begin{array}{lll}200 & \mathrm{~g} / 1 & \text { Kälberhirninfusion } \\ 250 & \mathrm{~g} / \mathrm{l} & \text { Rinderherzinfusion } \\ 10 & \mathrm{~g} / \mathrm{l} & \text { Proteose Pepton } \\ 2,0 & \mathrm{~g} / 1 & \text { Dextrose } \\ 5,0 & \mathrm{~g} / 1 & \mathrm{NaCl} \\ 2,5 & \mathrm{~g} / 1 & \mathrm{Na}_{2} \mathrm{HPO}_{4}\end{array}$

Die Brain-Heart-Infusion wurde nach der Zubereitung für 15 min bei $121{ }^{\circ} \mathrm{C}$ autoklaviert. In regelmäßigen Abständen sowie vor Verwendung wurde die Sterilität durch Inkubation einer Probe für 24 h überprüft.

\subsubsection{Zellkultur}

Die in dieser Arbeit genutzte Caco2-Zelllinie (DSMZ No. ACC 169) wurde ursprünglich aus einem Kolon-Adenokarzinom eines 72-jährigen kaukasischen Patienten isoliert. Diese seit 1974 etablierte Zelllinie wird von Professor A. Bacher, Technische Universität München, vertrieben. Caco2- Zellen sind adhärente, epitheliale Zellen, welche bei einer Temperatur von $37^{\circ} \mathrm{C}$ und einer mit $5 \% \mathrm{CO}_{2}$ angereicherten Atmosphäre inkubiert werden. Dabei weisen sie eine Verdopplungszeit von cirka $80 \mathrm{~h}$ auf.

Zum Anlegen einer Subkultur wurde alle 5-6 Tage ein 1:6- bis 1:10- Splitting der Zellen unter Verwendung von Trypsin/EDTA vorgenommen. Die Langzeitlagerung erfolgte mit 70\% Medium, 20\% FCS, 10\% DMSO, 1-2×10 Zellen pro Kryosystem. 


\subsubsection{Zellkulturmedien}

Standardvollmedium zur Zellkultivierung

$500 \mathrm{ml}$ Dulbeccós minimal essential medium (DMEM)

$50 \quad \mathrm{ml}$ inaktiviertes FCS

$5 \quad \mathrm{ml} \quad$ Penicillin/Streptomycin $(1000 \mathrm{mg} / \mathrm{ml})$

$5 \quad \mathrm{ml} \quad$ Non-essential-Aminoacids (100x)

Medium für Langzeitlagerung von Zellkulturen

$\begin{array}{ll}70 \% & \text { DMEM } \\ 20 \% & \text { FCS } \\ 10 \% & \text { DMSO }\end{array}$

2.1.4 Antikörper

2.1.4.1 Patientenseren

2.1.4.1.1 anti-Campylobacter-jejuni-Serum

Im Rahmen der Routinediagnostik standen Seren zur Verfügung, die von Patienten mit Campylobacter-jejuni-positivem Kulturbefund, klinisch manifester Campylobakteriose und 
Nachweis von Campylobacter-jejuni-spezifischen IgG- bzw. IgM-Antikörpern stammten. Die Patientenseren wurden gepoolt und gegen konfluente Caco2- Zellen adsorbiert.

\begin{tabular}{|l|l|l|}
\hline & IgG & IgA \\
\hline A22 & + & + \\
\hline A21 & + & - \\
\hline A28 & + & + \\
\hline
\end{tabular}

Tabelle 3: Antikörpernachweis in Patientenseren

\subsubsection{2 anti-dsDNA-Serum}

Das Patientenserum wurde uns freundlicherweise von der Abteilung Immunologie der Universität Göttingen zur Verfügung gestellt und 1:500 in PBS, mit 1\% BSA verdünnt, eingesetzt.

\subsubsection{Zytochromkonjugierte Sekundärantikörper}

Ziege-anti-Human-IgG (H+L) TRITC-konjugiert

Ziege-anti-Human-IgG (H+L) CY2-konjugiert
Dianova, Hamburg, Deutschland

Dianova, Hamburg, Deutschland

Für die indirekte Immunfluoreszenz wurden die Sekundärantikörper 1:200 in PBS mit 1\% BSA verdünnt. 


\subsubsection{Verbrauchsmaterialien}

Agarose Neeo Ultraqualität

Ammoniumchlorid

Bluejuice Gel loading buffer 10x

Bovines Serumalbumin $30 \%$ (BSA)

Campy Pack plus Mikroaerophiles System

Dulbecco’s MEM

Dulbecco's PBS

Eppendorfcups

Essigsäure

Ethidiumbromid

Fetal calf serum (FCS)

Gentamicin (-sulfat)

Glasdeckplättchen $\varnothing 12$ mm

Glucose

Glycerin

Halbmikroküvetten 1,5 ml

Kaliumacetat

Kryobank-Stammhaltungssystem für Mikroorganismen

Methanol 100\%

Matrixpolymer Matrigel
Roth, Karlsruhe

Roth, Karlsruhe

Invitrogen, Karlsruhe

Sigma, Deisenhofen

Becton Dickinson, Heidelberg

Invitrogen, Karlsruhe

GibcoBRL, Karlsruhe

Eppendorf, Hamburg

Roth, Karlsruhe

Sigma, Deisenhofen

Biochrom, Berlin

Sigma, Deisenhofen

Merck, Hannover

Sigma, Deisenhofen

Roth, Karlsruhe

Brand, Wertheim

Roth, Karlsruhe

Mast Diagnostika

Roth, Karlsruhe

BD Bioscience, Heidelberg 
Minimal essential medium Dulbecco's

Mowiol 4-88

Multischalen 24well

Multischalen 6well

Nalidixinsäure

Natriumazid

Natriumhydroxid

Non-essential-Aminoacids (100x)

Novobiocin

Objektträger-Aufbewahrungsbox

PBS Dulbecco's

Parafilm

Paraformaldehyd

Penicillin/Streptomycin 1000 mg/ml

Salzsäure

SDS

Tetracyclin

TRIS

Trypsin 10x/EDTA

Zellkulturflasche, $75 \mathrm{~cm}^{2}$

Zellkulturflasche, $175 \mathrm{~cm}^{2}$
GibcoBRL, Karlsruhe

Hoechst, Frankfurt

Nunc, Wiesbaden

Nunc, Wiesbaden

Sigma, Deisenhofen

Sigma, Deisenhofen

Sigma, Deisenhofen

GibcoBRL, Karlsruhe

Sigma, Deisenhofen

Merck, Darmstadt

Gibco BRL, Karlsruhe

American National Can.

Sigma, Deisenhofen

Biochrom, Berlin

Roth, Karlsruhe

Biometra, Göttingen

Sigma, Deisenhofen

Roth, Karlsruhe

Biochrom, Berlin

Nunc, Wiesbaden

Nunc, Wiesbaden 
Weitere verwendete Verbrauchsmaterialien wie Einwegspritzen, Petrischalen, Plastikröhrchen und Pipettenspitzen wurden von den Firmen Costar, Schütt, Roth und Eppendorf bezogen.

\subsubsection{Antibiotikatestplättchen}

In Klammern ist die Wirkstoffmenge pro Testplättchen angegeben.

$\begin{array}{ll}\text { Erythromycin }(15 \mu \mathrm{g}) & \text { Oxoid, Wesel } \\ \text { Tetracyclin }(30 \mu \mathrm{g}) & \text { Oxoid, Wesel } \\ \text { Ampicillin }(10 \mu \mathrm{g}) & \text { Oxoid, Wesel } \\ \text { Ciprofloxacin }(50 \mu \mathrm{g}) & \text { Oxoid, Wesel } \\ \text { Gentamicin }(10 \mu \mathrm{g}) & \text { Oxoid, Wesel }\end{array}$

\subsubsection{Technische Geräte}

Brutschrank HERAEUS BB 16 CU

Brutschrank HERAEUS B20

Bunsenbrenner, Flammi S

Feinwaage BL 310

Gelelektrophoresekammer

Transilluminator Bio Doc II

Heizrührer MR 3001

Mikroskop Model CK2

Tischmikroskop

Mikroskopierkamera DM RHC

Mikrowelle $800 \mathrm{~W}$

Mikrozentrifuge 5417 R
Kendro, Hanau

Kendro, Hanau

Schütt, Göttingen

Sartorius, Göttingen

Kreutz, Stuttgart

Biometra, Göttingen

Heidolph, Schwabach

Olympus, Hamburg

Carl Zeiss, Jena

Leica, Bensheim

Severin;Sundern

Eppendorf, Hamburg 
Netzgerät EPS 301

Netzgerät EPS1001

pH-Meter Calimatic 766

Pipettierhilfe, Pipetus akku

Schüttelinkubator Typ SM 30A control

Spectrophotometer Ultrospec 1000

Sterilbank

Vortexer reax top

Wasserbad mit Horizontalschüttler GFL 1092
Amersham Pharmacia, Braunschweig

Amersham Pharmacia, Braunschweig

Knick, Berlin

Hirschmann Laborgeräte, Eberstadt

Edmund Bühler, Tübingen

Pharmacia Biotech, Freiburg

BDK, Sonnenbühl

Heidolph, Schwabach

Rettberg, Göttingen

Als verwendete Kühlgeräte dienten ein handelsüblicher Kühlschrank mit einer Kühltemperatur von $4^{\circ} \mathrm{C}$ sowie ein Gefrierschrank mit einer Kühltemperatur von $-20^{\circ} \mathrm{C}$. Das Kryosystem mit den verwendeten Bakterienisolaten wurde in einem Gefrierschrank mit einer Kühlleistung von $-70^{\circ} \mathrm{C}$ aufbewahrt. Die Caco2-Zellen wurden in einem Flüssigstickstoffkontainer gelagert.

2.1.7 Puffer und Lösungen

Blockierungslösung

Elektrophoresepuffer

Fixierungslösung für Immunfluoreszenztest
$270 \mathrm{ml} \quad$ PBS

$30 \mathrm{ml}$ BSA $(30 \%)$

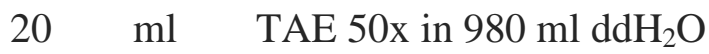

$90 \quad \mathrm{ml} \quad$ Ampuwa 


$\begin{array}{lllll}4 & \mathrm{~g} & \text { Paraformaldehyd } \\ 10 & \mathrm{ml} & \mathrm{PBS} 10 \mathrm{x} \\ 1 & \mathrm{M} & \mathrm{NaOH} \\ \text { Mowiol Mounting Medium } & 2,4 & \mathrm{~g} & \text { Mowiol@4-88 } \\ & 6,0 & \mathrm{~g} & \text { Glycerol } \\ 5,38 & \mathrm{ml} & \text { Ampuwa } \\ & 12 & \mathrm{ml} & 0,2 \mathrm{M} \text { Tris } \mathrm{HCl}(\mathrm{pH} \mathrm{8,5)}\end{array}$

Herstellung von Mowiol Mounting Medium

2,4 g Mowiol wurden in 6,0 g Glycerol durch permanentes Rühren für 1h gelöst. Nach Zugabe von 5,38 ml Ampuwa wurde erneut für $2 \mathrm{~h}$ gerührt und $12 \mathrm{ml} 0,2 \mathrm{M}$ Tris-HCl zugegeben. Unter ständigem Rühren wurde die Lösung für 30 min bei $50{ }^{\circ} \mathrm{C}$ inkubiert und danach bei $5000 \mathrm{~g}$ für 15 min zentrifugiert, um einen klaren Überstand zu erhalten. Die Stammlösung wurde auf Aliquots aufgeteilt, welche bis zur Verwendung bei $-20{ }^{\circ} \mathrm{C}$ gelagert wurden.

10x PBS

$20 \mathrm{mM}$

$\mathrm{KH}_{2} \mathrm{PO}_{4}(\mathrm{pH} 7,4)$

$80 \mathrm{mM}$

$\mathrm{Na}_{2} \mathrm{HPO}_{4}$

$1,83 \mathrm{M}$

$\mathrm{NaCl}$

TAE-Puffer 50X

$\begin{array}{lll}2,0 & \mathrm{M} & \text { Tris Puffer } \\ 50 & \mathrm{mM} & \text { EDTA }(\mathrm{pH} 7,5) \\ 5,75 & \%(\mathrm{v} / \mathrm{v}) & \text { Essigsäure }\end{array}$

Plasmidpräparationslösung 1

$50 \quad \mathrm{mM}$

Glukose

(Resuspensionspuffer)

$25 \mathrm{mM}$

Tris $\mathrm{pH} 8$ 
$10 \mathrm{mM} \quad$ EDTA

Plasmidpräparationslösung 2

$0,2 \quad \mathrm{M}$

$\mathrm{NaOH}$

(Lysepuffer)

$1 \%$

SDS

Plasmidpräparationslösung 3

29,45 g

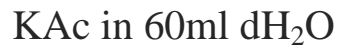

(Fällungsreagenz)

$11,5 \mathrm{ml} \quad$ Essigsäure

28,5 ml

$\mathrm{dH}_{2} \mathrm{O}$

\subsubsection{Kommerzielle Kits}

Api campy

BioMérieux, Marcy l'Etoile, Frankreich

Gene Path Group 1 Reagent Kit

Bio Rad, Hercules, CA, USA

Plasmid mini Kit

Qiagen, Hilden

2.1.8.1 Pulsfeldgelelektrophorese (PFGE)-Kit-Komponenten

Zell-Suspension-Puffer

Embedding-Agarose

Proteinase-K-Puffer

Proteinase K

10x Waschpuffer

Plug molds

Lysis-Puffer I

Lysozym/Lysostaphin (25mg/ml; 2mg/ml)

Restriktions-Enzym Sma I $(5 \mathrm{U} / \mu \mathrm{l})$

Sma I Puffer $\mathrm{y}^{+}$tango

Lambda-ladder-Molekularmassenstandard 


\subsubsection{Api-campy-kit-Komponenten}

AUX Medium:

$2 \mathrm{~g}$

$1,5 \mathrm{~g}$

$82,8 \mathrm{mg}$

$250 \mathrm{mg}$

35,9mg Vitamine/Nährsubstrate

0,04M Phosphatpuffer

$(\mathrm{pH}=7,1)$

Ammoniumsulfat

Agar

Anorganische Salze

Aminosäuren
Sulfanilsäure

Essigsäure

$\mathrm{H}_{2} \mathrm{O}$

N,N-Dimethyl-1-Naphthylamin

Essigsäure

$\mathrm{H}_{2} \mathrm{O}$

Fast Blue BB $(>0,1 \%)$

Natriumlaurylsulfat

Organische Lösungsmittel

Ninhydrin

2-Methoxyethanol

NIN Reagenz:

$7 \mathrm{~g}$

$100 \mathrm{ml}$

$\begin{array}{lll}\text { NIT 1 Reagenz: } & 0,4 \mathrm{~g} & \text { Sulfanilsäure } \\ 30 \mathrm{~g} & \text { Essigsäure } \\ 70 \mathrm{ml} & \mathrm{H}_{2} \mathrm{O} \\ & & \\ \text { NIT2 Reagenz: } & 0,6 \mathrm{~g} & \text { N,N-Dimethyl-1-Naphthylamin } \\ & 30 \mathrm{~g} & \text { Essigsäure } \\ & 70 \mathrm{ml} & \mathrm{H}_{2} \mathrm{O} \\ & & \\ & & \\ \text { FB Reagenz: } & 0,35 \mathrm{~g} & \text { Fast Blue BB (>0,1\%) } \\ & 7,5 \mathrm{mg} & \text { Natriumlaurylsulfat } \\ & 100 \mathrm{ml} & \text { Organische Lösungsmittel } \\ & & \\ 7 \mathrm{~g} & \text { Ninhydrin } \\ 100 \mathrm{ml} & \text { 2-Methoxyethanol } \\ \text { NIN Reagenz: } & & \end{array}$




\section{$2.2 \quad$ Methoden}

2.2.1 Isolierung, Identifizierung und biochemische Charakterisierung klinischer Campylobacter-jejuni- Isolate einschließlich Erstellung qualitativer Resistenzprofile

\subsubsection{API Campy}

Alle Campylobacter-jejuni-Isolate stammten aus Stuhlkulturen der bakteriologischen Routinediagnostik der damaligen Abteilung Bakteriologie der Universitätsklinik Göttingen. Diese Isolate wurden auf Columbia Blut-Agar überimpft und für $24 \mathrm{~h}$ mikroaerophil bei $42{ }^{\circ} \mathrm{C}$ bebrütet. Im Anschluss erfolgte die Erstellung eines biochemischen Profils mittels des kommerziell erhältlichen API Campy-Systems zur Subtypisierung von Campylobacter Spezies in einem standardisierten Test.

Der Test besteht aus zwei Komponenten: im ersten Teil wurde unter aeroben Wachstumsbedingungen die Fähigkeit des zu testenden Keims geprüft, spezifische enzymatische Schlüsselreaktionen durchführen zu können. Diese sind im Einzelnen:

- Ureaseaktivität

- $\quad$ Nitratreduktion

- $\quad$ Esteraseaktivität

- Hippurathydrolyse

- Gamma-Glutamyltransferaseaktivität

- $\quad$ Tetrazoliumreduktion

- Pyrrolidonyl-Arylamidaseaktivität

- $\quad$ L-Arginin-Arylamidaseaktivität

- $\quad$ L-Aspartat-Arylamidaseaktivität

- $\quad$ Alkalische Phosphataseaktivität. 
Die dabei entstehenden Stoffwechselprodukte wurden direkt oder nach Zugabe der entsprechenden Substrate und Indikatoren nach Herstellerangabe durch Farbumschläge sichtbar gemacht.

Im zweiten Testteil wurden in einem Minimalmedium unter mikroaerophilen Bedingungen diverse Assimilationsreaktionen sowie einige Antibiotikaresistenzen geprüft:

Substrate der Assimilationsreaktionen:

- Glukose

- Succinat

- Acetat

- Propionat

- Malat

- Citrat.

Zur Prüfung von Antibiotikaresistenzen eingesetzte antibiotische Wirkstoffe:

- Nalidixinsäure

- Cefazolin

- Erythromycin.

Die mitgelieferten Teststreifen wurden für beide Testbereiche nach Herstellerangaben mit einer Bakteriensuspension des $\mathrm{zu}$ testenden Isolates beschickt, inkubiert und ausgewertet. Eine weiterführende Charakterisierung erfolgte durch Antibiotikaresistenzbestimmung in einem semiquantitativen, standardisierten Agardiffusions-Hemmhoftest mittels kommerziell erhältlicher Antibiotikaplättchen. Dabei wurde jedes klinische Isolat auf Sensibilität bzw. Resistenz gegenüber den typischen im klinischen Alltag eingesetzten Antibiotikagruppen hin untersucht:

- Erythromycin

- Ciprofloxacin 
- Tetracyclin

- Ampicillin

- Gentamicin.

\subsubsection{Weiterführende Charakterisierung}

Des Weiteren wurden die DNAse-Aktivitäten sowie die Katalaseaktivitäten der isolierten Bakterienstämme getestet:

Test auf DNAse-Aktivität

Prinzip: Der Testagar enthält DNA. Polymerisierte DNA präzipitiert bei Anwesenheit von Salzsäure und verfärbt den Agar opak. Bei Mikroorganismen, die DNA mittels DNAse abbauen, entsteht aufgrund der ausbleibenden Präzipitation ein heller Hof um die Bakterienkolonie.

Durchführung:

Auf DNAse-Testagar wurde eine Kolonie des zu testenden Bakterienstammes mit einer Impfschlinge strichförmig ausgebracht und anschließend für $24 \mathrm{~h}$ mikroaerophil bei $37{ }^{\circ} \mathrm{C}$ bebrütet. Nach Flutung der Agarplatte mit $1 \mathrm{~N} \mathrm{HCl}$ färbt sich der Agar opak, während um DNAse-produzierende Bakterienkolonien ein heller Hof bestehen bleibt.

\section{$\underline{\text { Test auf Katalase-Aktivität }}$}

Auf einem Objektträger wurden einige Tropfen einer 3\%igen Wasserstoffperoxidlösung aufgetragen und mittels einer Impfschlinge mit einer Kolonie des $\mathrm{zu}$ testenden Bakterienstammes verrieben. Die deutliche Gasbildung weist dabei auf das Vorhandensein des Enzyms Katalase hin.

$2 \mathrm{H}_{2} \mathrm{O}_{2} \longrightarrow 2 \mathrm{H}_{2} \mathrm{O}+\mathrm{O}_{2}$ 
2.2.2 Bestimmung des log-Phasen-Wachstums von C.jejuni-Isolaten unter standardisierten Bedingungen

Der zu untersuchende Bakterienstamm wurde aufgetaut, und für $24 \mathrm{~h}$ auf frischem ColumbiaBlut-Agar bei $42{ }^{\circ} \mathrm{C}$ und mikroaerophiler Atmosphäre kultiviert. Danach erfolgte die Anlage einer Vorkultur: ein 50-ml-Falcon-Röhrchen wurde mit 10ml steriler Brain-Heart-Infusion (BHI) beschickt und unter sterilen Kautelen mit einer einzelnen Bakterienkolonie von der zuvor angelegten Columbia-Blut-Agar-Platte beimpft. Die so angelegte Vorkultur wurde für $14 \mathrm{~h}$ mikroaerophil bei $37{ }^{\circ} \mathrm{C}$ in einem Horizontalschüttler bei $120 \mathrm{U} / \mathrm{min}$ bebrütet. $\mathrm{Im}$ Anschluss wurde die optische Dichte als Maß für das Bakterienwachstum photometrisch bei einer Wellenlänge von $\lambda=550 \mathrm{~nm}$ ermittelt. Durch Volumensubstitution einer definierten Menge BHI wurden die Vorkulturen auf eine Extinktion von 0,1 bei $\lambda=550 \mathrm{~nm}$ titriert. $10 \mathrm{ml}$ der so eingestellten Bakteriensuspension wurden bei $3300 \mathrm{U} / \mathrm{min}$ für 5 min zentrifugiert, der Überstand dekantiert, das Bakterienpellet in $2 \mathrm{ml}$ steriler BHI resuspendiert und anschließend in $250 \mathrm{ml}$ BHI in einem 500-ml- Glaskolben aufgenommen.

Mit dem Startzeitpunkt der Messung $\mathrm{t}=0$ erfolgte die Inkubation bei $37^{\circ} \mathrm{C}$, in mikroaerophiler Atmosphäre in einem Horizontalschüttler bei 120 U/min. In regelmäßigen Abständen wurde die Inkubation temporär unterbrochen, eine $2 \mathrm{ml}$ Probe der Suspension unter sterilen Bedingungen entnommen und ihre optische Dichte photometrisch bestimmt. Die Beobachtung des Bakterienwachstums erfolgte über einen Zeitraum von 16 Stunden, mindesten jedoch bis die Plateauphase des Wachstums erreicht war.

2.2.3 Kultivierung und Subkultivierung von humanen Caco2-Zellen

2.2.3.1 Auftauen der Zellen

Die Caco2-Zellen wurden zur Langzeitaufbewahrung in DMSO-Lösung bei $-196{ }^{\circ} \mathrm{C}$ in flüssigem Stickstoff gelagert. Zum Auftauen einer Zellcharge wurde ein Kryoröhrchen entnommen und sofort auf Trockeneis gelagert. Unter sterilen Bedingungen wurde sofort nach Verflüssigung die enthaltene Zellsuspension in eine 25-ml-Zellkulturflasche überführt und mit $10 \mathrm{ml}$ des auf $37{ }^{\circ} \mathrm{C}$ vorgewärmten DMEM Komplettmediums verdünnt. Die Inkubation der Zellen erfolgte für 4-6 Tage bei $37^{\circ} \mathrm{C}$ in mit $5 \% \mathrm{CO}_{2}$ angereicherter Atmosphäre. Alle 24 bis 
$48 \mathrm{~h}$ erfolgte ein kompletter Wechsel des Zellkulturmediums. Bei Ausbildung eines konfluenten Zellrasens wurden die Zellen abtrypsiniert und zur weiteren Subkultivierung als 1:5- bis 1:10-Split auf größere Zellkulturflaschen verteilt.

\subsubsection{Ernte der Caco2-Zellen zur weiteren Subkultivierung}

Der konfluente Caco2-Zellrasen wurde nach mikroskopischer Kontaminationskontrolle 2x mit jeweils $10 \mathrm{ml}$ sterilem, auf $37^{\circ} \mathrm{C}$ vorgewärmten PBS sorgfältig gewaschen, mit $2 \mathrm{ml}$ einer Trypsin/EDTA Lösung beschickt und für cirka 5 min bei $37^{\circ} \mathrm{C}$ inkubiert. Durch vorsichtiges Beklopfen der Flaschenwand wurden die Zellen möglichst vollständig in Suspension gebracht. Der enzymatische Prozess wurde durch die Zugabe von $8 \mathrm{ml}$ des vorgewärmten DMEM Komplettmediums gestoppt, die Zellen als 1:5- bis 1:10-Split auf weitere Zellkulturflaschen mittlerer Größe verteilt und mit DMEM-Komplettmedium auf ein Gesamtvolumen von jeweils $25 \mathrm{ml}$ pro Zellkulturflasche ausgedehnt. Die Inkubation der Zellen erfolgte bei $37{ }^{\circ} \mathrm{C}$ in mit $5 \% \mathrm{CO}_{2}$ angereicherter Atmosphäre.
2.2.3.3 Beschichtung von Glasdeckplättchen mit einem biologischen Oberflächenpolymer zur Optimierung der Adhärenzeigenschaften der Caco2- Zellen

Das Matrigel®-Biopolymer wurde nach Herstellerangaben mit sterilem Ampuwa 1:50 verdünnt und bis zur Verwendung aliquotiert bei $-20{ }^{\circ} \mathrm{C}$ aufbewahrt. Die Glascoverslips wurden dampfsterilisiert und steril gelagert. Zur Oberflächenbeschichtung wurden mehrere 10 $\mu l$-Tropfen des bis auf $4{ }^{\circ} \mathrm{C}$ erwärmten Matrigels ${ }^{\circledR}$ in eine sterile Glaspetrischale gegeben, die Coverslips darüber gelegt und bei RT für 1h inkubiert. Danach wurden die Coverslips 2x mit sterilem PBS gewaschen, mit einer Pinzette in eine 24-Loch-Zellkulturplatte überführt und für 30 min bei RT getrocknet. Die Aussaat der Caco2-Zellen erfolgte unmittelbar im Anschluss. 


\subsubsection{Aussaat der Caco2-Zellen auf oberflächenveränderte Glasdeckplättchen}

Die Zellen wurden wie im letzten Abschnitt beschrieben bei Konfluenz abtrypsiniert, in $10 \mathrm{ml}$ Komplettmedium aufgenommen und auf Eis gestellt. $10 \mu \mathrm{l}$ der Zellsuspension wurden entnommen, im Verhältnis 1:10 bzw. 1:100 mit Ampuwa verdünnt, und in der Neubauerzählkammer wurde eine Zellzahlbestimmung vorgenommen. Die definitive Caco2Zelldichte von 150.000-200.000 Zellen/ $\mu$ l wurde durch Verdünnung mit dem entsprechenden Volumen an DMEM-Komplettmedium erreicht. Die Aussaat erfolgte durch Zugabe von $1 \mathrm{ml}$ Zellsuspension pro Loch einer 24-Loch-Multiwellschale mit anschließender Inkubation der Zellen bei $37{ }^{\circ} \mathrm{C}$ in mit $5 \% \mathrm{CO}_{2}$ angereicherter Atmosphäre. Das Medium wurde alle 24-48 h vollständig ersetzt, das Zellwachstum regelmäßig mikroskopisch kontrolliert und das Erreichen der Konfluenz der Caco2-Zellen dokumentiert.

\subsubsection{Genetische Manipulation der Bakterienstämme}

2.2.4.1 Plasmidheilung tetrazyklinresistenter C. jejuni-Isolate

Die Tetrazyklinresistenz von $C$. jejuni wird durch auf den Plasmiden gelegenen Genen determiniert. Als Plasmidheilung wird der vollständige irreversible Verlust eines Plasmids definiert. Er kann u.a. durch Hemmung des Replikationsmechanismus der Bakterienzelle, durch DNA-interkalierende Substanzen oder durch Hemmstoffe der DNA-Gyrase, induziert werden. Als Screening auf Plasmidverlust wurde der Phänotypwechsel von tetrazyklinresistent zu tetrazyklinsensibel verwendet.

\section{Plasmidheilung durch Ethidiumbromid}

Die Stämme A6, A7, A13, A14 und A22 wurden für jeweils 24 h, 48 h und 120 h in Campylobacter-Flüssignährmedien mit aufsteigenden Ethidiumbromidkonzentrationen von 3 $\mu \mathrm{g} / \mathrm{ml}$ bis $20 \mu \mathrm{g} / \mathrm{ml}$ kultiviert, um die stammspezifische subletale Dosis $\mathrm{zu}$ ermitteln. Einzelkolonien der so behandelten Stämme wurden simultan jeweils auf Columbia-BA und Tet-Agar (Tetrazyklin-Agar) überimpft und das Bakterienwachstum nach $24 \mathrm{~h}$ Bebrütung bei $42{ }^{\circ} \mathrm{C}$ und mikroaerophiler Atmosphäre kontrolliert. 


\section{Plasmidheilung durch Novobiocin}

Die Stämme A6 und A7 wurden für $24 \mathrm{~h}$ bis $48 \mathrm{~h}$ in BHI supplementiert und mit Novobiocin in ansteigenden Konzentrationen kultiviert $(10 \mu \mathrm{g} / \mathrm{ml}, 25 \mu \mathrm{g} / \mathrm{ml}, 50 \mu \mathrm{g} / \mathrm{ml}, 100 \mu \mathrm{g} / \mathrm{ml}, 200$ $\mu \mathrm{g} / \mathrm{ml}$ Novobiocin). Desweiteren wurde bei den Stämmen B1 und B2 die subletale Novobiocindosis bei standardisierter Inokulationsmenge an Bakterien von $5 \times 10^{7} \mathrm{KBE} / \mathrm{ml}$ ermittelt. Dazu wurden die Bakterien in Eppendorfröhrchen in $1 \mathrm{ml}$ BHI+Novobiocin in Konzentrationen von $5 \mu \mathrm{g} / \mathrm{ml}$ bis $50 \mu \mathrm{g} / \mathrm{ml}$ für $48 \mathrm{~h}$ mikroaerophil bei $42{ }^{\circ} \mathrm{C}$ kultiviert. Die quantitative Bestimmung der Überlebensrate erfolgte photometrisch bei einer Wellenlänge von $\lambda=550 \mathrm{~nm}$ nach Eichung auf die optische Dichte von BHI. Darauf basierend wurden weitere Ansätze der Stämme B1 und B2 wie oben beschrieben mit Novobiocin behandelt. Die Selektion tetrazyklinsensibler Klone erfolgte durch simultanes Ausstreichen der Einzelkolonie auf Columbia-BA und Tet-Agar bzw. nach der im folgenden Abschnitt beschriebenen Replica plating Methode.

\subsubsection{Selektion tetrazyklinsensibler Klone mit der Replica-plating-Methode}

Die Selektion der durch Plasmidheilung unter Novobiocin generierten tetrazyklinsensiblen Klone erfolgte mittels der Replica-plating-Methode. Dazu wurde ein massiver Holzzylinder (Durchmesser cirka $6 \mathrm{~cm}$ ) unter Zuhilfenahme einer Metallschelle mit einem sterilen Samttuch überspannt. Die Bakterienisolate wurden nach Behandlung mit Novobiocin wie im letzten Abschnitt beschrieben in einer Dichte von $10^{2}$ bis $10^{3} \mathrm{KBE}$ pro Agar Platte ausgesät und für 15-20 h mikroaerophil bei $42{ }^{\circ} \mathrm{C}$ bebrütet. Von der so vorbereiteten Master-Platte werden die Bakterienkolonien durch das straff gespannte Samttuch auf eine Tet-Agar Platte übertragen. Nach Bebrütung der Tet-Agar Platte für $20 \mathrm{~h}$ bei $42{ }^{\circ} \mathrm{C}$ in mikroarophiler Atmosphäre wurden korrespondierende Bakterienkolonien auf beiden Platten verglichen und die tetrazyklinsensiblen Klone von der Master-Platte isoliert. Diese wurden erneut auf Columbia-BA subkultiviert. Zur Bestätigung des Plasmidverlustes wurde im Anschluss mit den isolierten Klonen eine Plasmid-Präparation durch die im Folgenden beschriebene AlkaliLysis-Prozedur durchgeführt. 


\subsubsection{Alkali-Lysis-Prozedur zur Präparation von bakteriellen Plasmiden}

$1 \mathrm{ml}$ Bakterienkultur wurde bei RT für $1 \mathrm{~min}$ bei $14000 \mathrm{U} / \mathrm{min}$ zentrifugiert, der Überstand dekantiert und das Bakterienpellet in $100 \mu \mathrm{l}$ eiskaltem Resuspensionspuffer gelöst. Nach der Zugabe von $200 \mu \mathrm{l}$ frisch hergestelltem Lysepuffer erfolgte die Äquilibrierung für 5 min auf Eis. Anschließend wurden $150 \mu$ Fällungsreagenz hinzugefügt und erneut für 5 min auf Eis äquilibriert. Anschließend erfolgte die Zentrifugation für 6 min bei RT mit $14000 \mathrm{U} / \mathrm{min} .400$ $\mu l$ des Überstandes wurden in ein neues Gefäß überführt. Die Fällung der Plasmid- DNA erfolgte durch Zugabe von $800 \mu 100 \%$ igen Ethanols mit anschließender Inkubation bei $20^{\circ} \mathrm{C}$ für $15 \mathrm{~min}$. Nach erneutem Zentrifugieren für $10 \mathrm{~min}$ bei $14000 \mathrm{U} / \mathrm{min}$ und $4{ }^{\circ} \mathrm{C}$ sowie dem anschließenden Verwerfen des Überstandes erfolgte die Salzauswaschung mit 70 \% igem Ethanol. Dem folgte erneutes Zentrifugieren zu denselben, bereits weiter oben beschriebenen, Konditionen. Die Lösung der Plasmid-DNA in $25 \mu$ Tris-Cl erfolgte nach Trocknung des Pellets für 5 min bei RT.

\subsubsection{Erzeugung isogener Varianten durch konjugativen Plasmidtransfer}

Die Plasmide pCjA9 bzw pCjA13, welche jeweils ein plasmidgebundenes Tetrazyklinresistenzgen ( Tet $_{\text {res }}$ ) tragen, wurden durch konjugativen Gentransfer in die nalidixinsäureresistenten $\left(\mathrm{Nal}_{\text {res }}\right)$, plasmidfreien Rezipientenstämme A34, A22 und A3 transferiert. Dadurch konnten die $\mathrm{Nal}_{\text {res }} /$ Tet $_{\text {res }}$ Transkonjuganten A3/pCjA9, A3/pCjA13, A22/pCjA9, A22/pCjA13, A34/pCjA9, A34/pCjA13 generiert werden.

Zur Erzeugung der Transkonjuganten wurden die Donorstämme (Tet res $_{\text {) }}$ A9 und A13 sowie die Rezipientenstämme ( $\left.\mathrm{Nal}_{\mathrm{res}}\right) \mathrm{A} 3, \mathrm{~A} 22$ und A34 über Nacht auf Columbia-BA supplementiert und mit $20 \mu \mathrm{g} / \mathrm{ml}$ Tetrazyklin für die Donorstämme bzw. $50 \mu \mathrm{g} / \mathrm{ml}$ Nalidixinsäure für die Rezipientenstämme kultiviert. Die Bakterien wurden geerntet und in PBS+DNAse I $25 \mu \mathrm{g} / \mathrm{ml}$ sowie $\mathrm{MgCl} 100 \mu \mathrm{M}$ suspendiert. Die optische Dichte wurde bis zu einer Extinktion von $\mathrm{E}=0.5$ bei $\lambda=550 \mathrm{~nm}$ titriert, was einer Bakterienzahl von cirka $2 \times 10^{9}$ KBE entspricht. Jeweils 0,1 ml der Bakteriensuspension eines Donors und eines Rezipienten wurden gemeinsam auf Columbia-BA $(+25 \mu \mathrm{g} / \mathrm{ml}$ DNAse) ausgestrichen und für $5 \mathrm{~h}$ bei $37{ }^{\circ} \mathrm{C}$ in $5 \% \mathrm{CO}_{2}$ angereicherter Atmosphäre bebrütet. Die Bakterien wurden geerntet und in $300 \mu \mathrm{l}$ PBS resuspendiert. Die Selektion der transkonjuganten Klone erfolgte durch 
Subkultivierung auf Columbia-BA $(+20 \mu \mathrm{g} / \mathrm{ml}$ Tetrazyklin $+50 \mu \mathrm{g} / \mathrm{ml}$ Nalidixinsäure) über Nacht bei $37^{\circ} \mathrm{C}$ in mit $5 \% \mathrm{CO}_{2}$ angereicherter Atmosphäre.

2.2.4.5 Qualitativer Nachweis der Plasmidakquirierung der Rezipientenstämme durch Plasmid-mini-Präparation

Das kommerziell erhältliche Plasmid-Präparations-Kit (Qiagen) basiert auf einem modifizierten Alkali-Lyse-Protokoll. Dabei wird Plasmid-DNA bei niedrigen Salzkonzentrationen und pH-Werten an einen Anionenaustauscher gebunden, wobei RNA, Proteine und höhermolekulare Verunreinigungen abgetrennt werden. Durch Anhebung des pH-Wertes und der NaCl-Konzentration auf $1250 \mathrm{mM}$ wird die gebundene Plasmid-DNA eluiert und in hochmolarer Salzlösung konzentriert, anschließend durch Isopropanolfällung präzipitiert und danach schrittweise entsalzt. Alle getesteten Bakterienisolate wurden zuvor auf Columbia-BA subkultiviert und für $24 \mathrm{~h}$ bei $42{ }^{\circ} \mathrm{C}$ mikroaerophil bebrütet. Die Präparation erfolgte nach Herstellerangaben und unter Verwendung der im Lieferumfang enthaltenen Chemikalien und Reagenzien sowie der Anionen-Austauscher-Harze. Nach Herstellerinformationen ist das angebotene System zur Isolierung von Plasmid-DNA bis 150 $\mathrm{kB}$ besonders effizient.

2.2.4.6 Pulsfeldgelelektrophorese (PFGE) von Donor- und Rezipientenstämmen sowie der erzeugten isogenen Varianten

Um eine spontane chromosomale Mutation der Rezipienten als Ursache des neuen tetrazyklinresistenten Phänotyps auszuschließen, wurden Donorstämme, Rezipientenstämme sowie die erzeugten isogenen Varianten als Transkonjuganten einer Pulsfeldgelelektrophorese der chromosomalen Bakterien-DNA im Sma I-Restriktionsenzymverdau mittels eines kommerziell erhältlichen PFGE-Kits unterzogen. Die Durchführung erfolgte entsprechend den Herstellerangaben und unter Verwendung der im Lieferumfang enthaltenen Geltaschen sowie der entsprechenden Chemikalien und Reagenzien. Abweichungen vom Standardprotokoll des Herstellers basierten auf Erkenntnissen von Ribot et al. (2001). Die Gelelektrophorese der vorbereiteten Proben wurde freundlicherweise von Frau Claudia Huppach der BE Krankenhaushygiene der Universität Göttingen vorgenommen. 


\section{Vorbereitung der Bakterienproben}

Dazu wurden die Bakterienstämme A34, A22, A3, A3/pCjA9, A3/pCjA13, A22/pCjA9, A22/pCjA13, A34/pCjA9, A34/pCjA13, A9 und A13 über Nacht auf Columbia-BA bei $37^{\circ} \mathrm{C}$ in $5 \% \mathrm{CO}_{2}$ angereicherter Atmosphäre kultiviert. Die Bakterien wurden geerntet, in jeweils 1 $\mathrm{ml}$ sterilen PBS suspendiert und für 2 min bei $10.000 \mathrm{U} / \mathrm{min}$ zentrifugiert. Die Größen der entstandenen Bakterienpellets wurden mit Referenzgrößen des Herstellers verglichen und an diese durch Verdünnung bzw. Volumenreduktion angepasst. Die Agarose wurde in einer Mikrowelle geschmolzen und bis zur weiteren Verwendung bei $50-55{ }^{\circ} \mathrm{C}$ äquilibriert. Die Bakterienpellets wurden vorsichtig jeweils in $100 \mu \mathrm{l}$ Zellsuspensionspuffer gelöst und anschließend für $15 \mathrm{~min}$ bei $50^{\circ} \mathrm{C}$ äquilibriert.

\section{Lyse der Bakterienproben}

Der Zellsuspension wurden $4 \mu \mathrm{l}$ Lysozym/Lysostaphin sowie $100 \mu \mathrm{l}$ der geschmolzenen Agarose zugegeben, gemischt und $100 \mu \mathrm{l}$ davon in die mitgelieferten Geltaschen gegeben. Nach Verfestigung zu Gelblöcken wurden diese in $2 \mathrm{ml}$ Eppendorfröhrchen überführt und die Zelllyse mit $500 \mu \mathrm{l}$ Lysispuffer, $20 \mu \mathrm{l}$ Lysozym/Lysostaphin durchgeführt (Inkubation für $1 \mathrm{~h}$ bei $37^{\circ} \mathrm{C}$ ). Nach dem Entfernen des Lysispuffers und dem anschließenden Waschen mit $1 \mathrm{x}$ Waschbuffer wurde $20 \mu \mathrm{l}$ Proteinase K in $500 \mu$ Proteinase K Puffer zugegeben und für 16 bis $20 \mathrm{~h}$ bei $50{ }^{\circ} \mathrm{C}$ inkubiert. Nach viermaligem Waschen der Gelblöcke mit jeweils $1 \mathrm{ml}$ Waschpuffer für je 30 min bei RT wurden diese bis zum anschließenden Sma I-Verdau bei $4{ }^{\circ} \mathrm{C}$ aufbewahrt.

\section{$\underline{\text { Sma I-Restriktionsverdau der Bakterienproben }}$}

Nach einem initialen Waschschritt der Gelblöcke mit jeweils 1ml Waschpuffer für 30 min bei $\mathrm{RT}$ in einem Schüttelinkubator wurden die Proben mit $500 \mu \mathrm{l}$ Sma I-Puffer versetzt und für 30 min bei RT inkubiert. Der eigentliche Verdau wurde mit $5 \mu$ l Sma I (entsprechen 25 units pro Gelblock) in $300 \mu \mathrm{l} \mathrm{Sma} \mathrm{I-Puffer} \mathrm{für} 20 \mathrm{~h}$ bei $25^{\circ} \mathrm{C}$ durchgeführt. Die so behandelten Proben wurden bis zur Durchführung der Gelelektrophorese bei $4^{\circ} \mathrm{C}$ in jeweils $500 \mu \mathrm{l}$ 1xWaschpuffer aufbewahrt. 


\subsubsection{Zellkulturversuche}

\subsubsection{Kulturelle Methode mit Hilfe des Gentamicin-Protektions-Assays (GPA)}

\section{Vorbereitung der Bakterienisolate}

Die zu testenden $C$. jejuni-Isolate wurden in Subkultur für $24 \mathrm{~h}$ auf Columbia-BA bei $42{ }^{\circ} \mathrm{C}$ in mikroaerophiler Atmosphäre kultiviert. Anschließend wurden die Bakterien in sterilem PBS in Suspension gebracht und photometrisch auf eine optische Dichte von 0,5 bei einer Wellenlänge von $\lambda=550 \mathrm{~nm}$ eingestellt (entspricht $10^{9} \mathrm{KBE} / \mathrm{ml}$ ). Eine weitere Verdünnung mit DMEM erfolgte im Verhältnis 1:10.

\section{Vorbereitung der Caco2-Zellen für den GPA}

Die Caco2- Zellen wurden, wie bereits in den vorderen Abschnitten beschrieben, in 24-LochMultischalen kultiviert und am zehnten postkonfluenten Tag für den Infektionsversuch eingesetzt. Vor Zugabe der Bakteriensuspension wurden die Zellen mikroskopisch auf Integrität des Zellrasens und Kontamination kontrolliert, sowie zweimal mit auf $37{ }^{\circ} \mathrm{C}$ vorgewärmtem PBS gewaschen.

\section{$\underline{\text { Infektion der Caco2-Zellen für den GPA }}$}

Pro Loch der Multischalen wurde $1 \mathrm{ml}$ der Bakteriensuspension $\left(\sim 10^{8} \mathrm{KBE}\right)$ verwendet. Zur zeitlichen Synchronisierung wurden die Bakterien für 2 min bei $400 \mathrm{U} / \mathrm{min}$ zentrifugiert und anschließend bei $37^{\circ} \mathrm{C}$ in $5 \% \mathrm{CO}_{2}$ angereicherter Atmosphäre für $2 \mathrm{~h}$ inkubiert. Nach einem intermediären Waschschritt (3 x 5 min mit PBS) wurde die Hälfte der Ansätze mit $250 \mu \mathrm{g} / \mathrm{ml}$ Gentamicin, die anderen Ansätze mit DMEM versetzt und für $3 \mathrm{~h}$ bei $37^{\circ} \mathrm{C}$ inkubiert. Durch zweimaliges Waschen mit $1 \mathrm{ml}$ PBS wurde das Antibiotikum entfernt und anschließend die Caco2-Zellen mit $500 \mu \mathrm{l}$ Triton X-100 0,01\% in PBS für 30 min bei $37{ }^{\circ} \mathrm{C}$ lysiert. Das Lysat der mit Antibiotikum behandelten Ansätze wurde in 1:1- bzw. 1:10-Verdünnungen in Duplikaten auf Columbia-BA ausplattiert. Die unbehandelten Ansätze wurden in Verdünnungsstufen 1:10 und 1:100 in Duplikaten auf Columbia-BA ausplattiert. Die Bestimmung der Infektionsdosis erfolgte durch Ausplattierung der Infektionssuspension auf Columbia-BA.

Bestimmung der Adhärenz und Invasionsraten durch Auszählung der Kolonien

Nach Bebrütung für $24 \mathrm{~h}$ bei $42{ }^{\circ} \mathrm{C}$ in mikroaerophiler Atmosphäre wurde durch Auszählung und Mittelwertbildung bei den mit Gentamicin behandelten Ansätzen die Invasionsrate 
bestimmt. Die unbehandelten Ansätze wurden zur Ermittlung der zellassoziierten Bakterien ausgezählt.

2.2.5.2 Indirekte Doppelimmunfluoreszenz zur differenzierten Darstellung intra- und extrazellulärer Bakterien in infizierten Caco2-Zellmonolayern

2.2.5.3 Präadsorption des Patientenserums gegen paraformaldehydfixierte Caco2Zellen

Zur möglichst vollständigen Unterdrückung eines unspezifischen Hintergrundsignals bei Immunfluoreszenzversuchen wurde das gepoolte Patientenserum gegen konfluente Caco2Zellen präadsorbiert. Dazu wurden jeweils $2 \mathrm{ml}$ des auf 1:50 mit Ampuwa verdünnten Patientenserums auf den konfluenten, paraformaldehydfixierten Caco2-Zellrasen gegeben und für $1 \mathrm{~h}$ bei RT inkubiert. Das präadsorbierte Serum wurde aliquotiert mit $\mathrm{NaN}_{3}$ bis zu einer Konzentration von $0,01 \%$ versetzt und bei $-20^{\circ} \mathrm{C}$ bis zur weiteren Verwendung aufbewahrt.

2.2.5.4 Status der Zellmembranintegrität humaner Caco2-Zellen nach der Fixierung mit $4 \%$ - iger Paraformaldehydlösung

Auf mit Matrigel beschichteten Glasdeckplättchen wachsende Caco2-Zellen wurden am zehnten postkonfluenten Tag zweimal mit auf $37{ }^{\circ} \mathrm{C}$ vorgewärmten PBS gewaschen und anschließend mit $4 \%$-iger frisch zubereiteter Paraformaldehydlösung für 30 min bei RT fixiert. Anschließend wurde durch dreimaliges Waschen mit PBS für $5 \mathrm{~min}$ das Paraformaldehyd vollständig entfernt. Das Quenching der Zellen wurde mit $\mathrm{NH}_{4} \mathrm{CL} 50 \mathrm{mM}$ für 15 min und das sich anschließende Blockieren mit $2 \%$ BSA in PBS für 30 min durchgeführt. Der antinukleäre Antikörper wurde 1:500 in Blockierungsreagenz verdünnt und für $1 \mathrm{~h}$ bei RT mit den Zellen inkubiert. Nach einem anschließenden Waschschritt (dreimal 5 min mit PBS bei RT) wurde zur Detektion ein Cy2-konjugierter Ziege-anti-human-Antikörper 1:400 in Blockierungsreagenz verdünnt verwendet (Inkubation $1 \mathrm{~h}$ bei RT). In einem zweiten parallel dazu durchgeführten Ansatz wurden die Caco2-Zellen vor der Markierung mit dem Primärantiköper für 30min mit eiskaltem Methanol behandelt. Nach einem finalen Waschschritt (dreimal 5 min mit PBS bei RT) wurden die Deckplättchen beider Ansätze mit 
Mowiol-Mounting-Medium auf geschnittenen Objektträgern konserviert und nach $12 \mathrm{~h}$ Aushärtung mikroskopisch beurteilt.

\subsubsection{Infektion humaner Caco2-Zellen mit mid-log-Phasen-C. jejuni-Kulturen}

Vorbereitung der Zellkulturen für den Immunfluoreszenzversuch

Die auf Glasdeckplättchen wachsenden Zellen befanden sich zum Zeitpunkt der Infektion am zehnten postkonfluenten Tag. 12-24 h vor der Infektion wurde ein kompletter Mediumwechsel durchgeführt und die Zellen lichtmikroskopisch auf Kontamination und Integrität des Zellrasens hin untersucht. Unmittelbar vor der Infektion wurden die Zellen zweimal mit serumfreien DMEM- Komplettmedium gewaschen.

Vorbereitung der Bakterienisolate für den Immunfluoreszenzversuch

Nach den Erkenntnissen der Versuche zum Wachstum von C. jejuni in BHI wurden pro Bakterienstamm $125 \mathrm{ml} \mathrm{C.} \mathrm{jejuni-BHI-Kultur} \mathrm{in} \mathrm{mid} \mathrm{log} \mathrm{Phase} \mathrm{gewonnen,} \mathrm{bei} 3300$ U/min bei $4{ }^{\circ} \mathrm{C}$ für 5 min zentrifugiert und in jeweils $2 \mathrm{ml}$ sterilem PBS resuspendiert. Die optische Dichte dieser Bakteriensuspension wurde photometrisch bestimmt und durch Zugabe einer entsprechenden Menge sterilen PBS auf eine Extinktion von $\mathrm{E}=0,5$ bei einer Wellenlänge von $\lambda=550 \mathrm{~nm}$ titriert. Durch anschließendes Verdünnen dieser Suspension (1:10 in DMEM ohne Zusätze) wurde die endgültige Infektionssuspension hergestellt. Durch Ausplattierung von

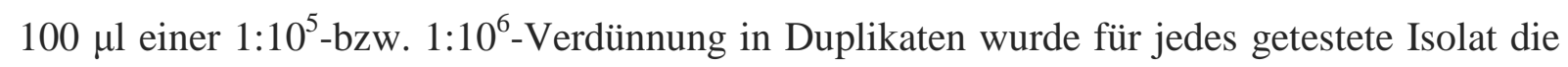
Infektionsdosis bestimmt.

\section{Infektion der Caco2-Zellen}

Jedes Bakterienisolat wurde in Quadruplikaten getestet. Pro Loch wurden $1 \mathrm{ml}$ der hergestellten Infektionssuspension auf die vorbereiteten Caco2-Zellen gegeben. Die Multiwellschallen wurden bei $4{ }^{\circ} \mathrm{C} 400 \mathrm{U} / \mathrm{min}$ für $5 \mathrm{~min}$ zentrifugiert, um eine zeitliche Synchronisierung der Infektion zu erreichen. Anschließend wurden die Zellen für $2 \mathrm{~h}$ bei $37{ }^{\circ} \mathrm{C}$ in $5 \% \mathrm{CO}_{2}$ angereicherter Atmosphäre inkubiert. Die Invasion wurde durch dreimaliges Waschen der infizierten Zellen mit PBS und anschließender Fixierung mit einer $4 \%$ igen Paraformaldehydlösung für 30 min gestoppt. Bis zur Immunfluoreszenzfärbung wurden die infizierten Zellen bei $4^{\circ} \mathrm{C}$ aufbewahrt. 


\subsubsection{Bestimmung der Adhärenz und Invasion durch differenzierte Antikörperreaktionen}

Alle Inkubationen mit Antikörpern wurden auf Parafilm mit jeweils $50 \mu 1$ der entsprechend verdünnten Antikörperlösung durchgeführt; für alle Waschschritte wurde eine 24fachMultiwellschale benutzt. Nach der Zugabe des ersten Sekundärantikörpers wurden alle weiteren Inkubationen im Dunkeln durchgeführt. Die infizierten und paraformaldehydfixierten Zellen wurden dreimal für 5 min bei RT mit PBS gewaschen und anschließend für 20 min mit jeweils $5 \mathrm{ml}$ 1\% BSA in PBS geblockt. Anschließend wurden die infizierten Zellen für $1 \mathrm{~h}$ bei RT mit dem gepoolten Patientenserum als human-antiCampylobacter-Primärantikörper 1:200 in PBS mit 1\% BSA inkubiert. Nachdem der Primärantikörper durch dreimaliges Waschen für 5 min mit PBS bei RT entfernt wurde, erfolgte die Inkubation mit einem TRITC-markierten Ziege-anti-Mensch- Sekundärantikörper 1:200 verdünnt in PBS mit $1 \%$ BSA für $1 \mathrm{~h}$ bei RT. Nach erneutem dreimaligem Waschen für 5 min mit PBS bei RT zum Entfernen des Sekundärantikörpers, wurden die Zellen mit eiskaltem Methanol für 5 min bei RT permeabilisiert und anschließend zweimal 5 min bei RT mit PBS gewaschen. Zur Detektion der zellassoziierten Keime wurden die Zellen erneut mit dem gepoolten Patientenserum wie bereits beschrieben behandelt. Anschließend wurde als Sekundärantikörper ein Cy-2 markierter Ziege-anti-Mensch- Antikörper 1:200 in PBS mit 1\% BSA verdünnt und für $1 \mathrm{~h}$ bei RT eingesetzt. Nach abschließendem dreimaligem Waschen der Zellen für 5min bei RT wurden die Glascoverslips unter Verwendung von Mowiol-MountingMedium auf Objektträgern fixiert. Nach der vollständigen Aushärtung bei RT wurden die Objektträger bis zur mikroskopischen Beurteilung bei $4{ }^{\circ} \mathrm{C}$ im Dunkeln aufbewahrt. Eine schematische Veranschaulichung des Prinzips der Doppelimmunfluoreszenz ist in Abbildung 2 dargestellt.

2.2.5.7 Bestimmung der Invasions- und Zellassoziationsraten durch fluoreszenzmikroskopische Auswertung

Die mikroskopische Beurteilung erfolgte mittels Fluoreszenzmikroskop bei 400facherVergrößerung. In 50 Gesichtfeldern (entspricht bei dieser Vergrößerungsstufe durchschnittlich 123 Caco2-Zellen/Gesichtsfeld) wurden die Bakterien auf ihre Fluoreszenzeigenschaften hin untersucht. Dabei wurden zunächst in einem Gesichtsfeld alle grün-fluoreszierenden Bakterien (intra- und extrazellulär) bestimmt und nach Wechsel des 
Filters solche Keime mit zusätzlich roter Fluoreszenzmarkierung (nur extrazellulär). Durch Bildung der Differenz beider Bakterienpopulationen wurde die Anzahl der zellinvasiven Keime ermittelt (entspricht den ausschließlich grün markierten Keimen).

Mittels der Mikroskopkamera und unter Verwendung der vom Hersteller mitgelieferten Kamerasoftware wurden einzelne Gesichtfeldausschnitte fotographisch dokumentiert.

\subsubsection{Untersuchung der Invasionskinetik}

Zur Beurteilung des zeitlichen Verlaufs der Invasion von C. jejuni in humane Caco2-Zellen wurden pro Isolat räumlich getrennte Ansätze von konfluenten Caco2-Zellen verwendet, die zeitgleich wie oben beschrieben infiziert wurden. Nach Ablauf einer Invasionszeit von jeweils $15 \mathrm{~min}, 1 \mathrm{~h}$ und $2 \mathrm{~h}$ wurde die Invasion durch Fixierung mit $4 \%$ Paraformaldehydlösung unterbrochen. Immunfluoreszenzfärbung und mikroskopische Auswertung erfolgten wie bereits beschrieben. 


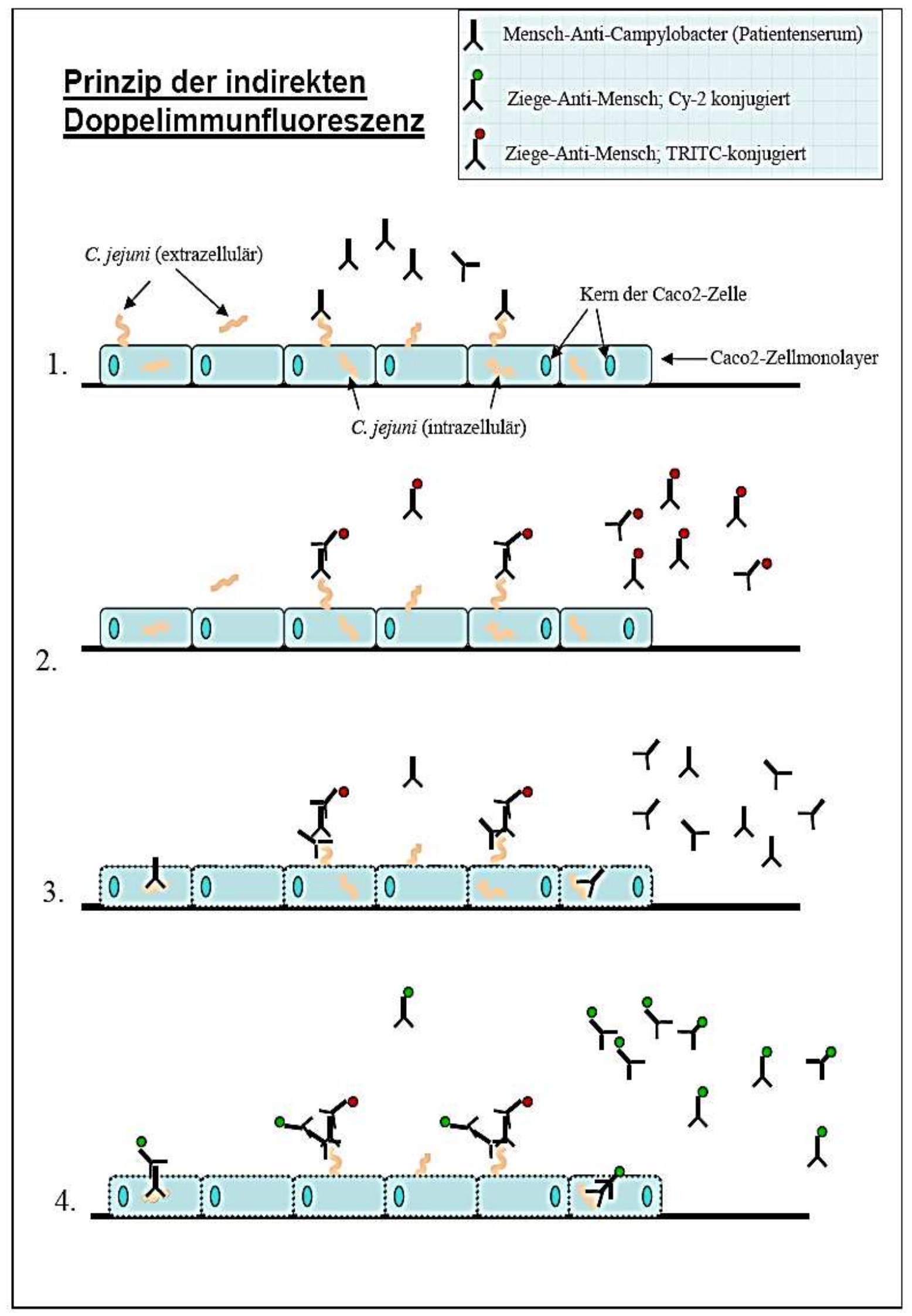

Abbildung 2: Prinzip der indirekten Doppelimmunfluoreszenz 


\section{ERGEBNISSE}

\subsection{Charakterisierung ausgewählter klinischer Isolate von C. jejuni}

Die ermittelten Resistenzprofile der verwendeten $C$. jejuni- Isolate sowie ihr Plasmidgehalt ist zusammenfassend in Tabelle 4 dargestellt.

\begin{tabular}{|l|l|l|l|l|l|l|}
\hline & Tetrazyklin & Erythromycin & Ampicillin & Ciprofloxacin & Gentamicin & Plasmid \\
\hline A3 & S & S & R & R & S & - \\
\hline A22 & S & S & S & R & S & $10,1 \mathrm{kB}$ \\
\hline A34 & S & S & R & R & S & - \\
\hline A9 & R & S & R & S & S & $40,5 \mathrm{kB}$ \\
\hline A13 & R & S & R & S & S & $41,4 \mathrm{kB}$ \\
\hline NCTC & S & S & S & S & S & - \\
\hline
\end{tabular}

Tabelle 4: Antibiotika-Resistenzprofile der verwendeten Wildtyp-Stämme von C. jejuni ( $\mathrm{S}=$ sensibel $\mathrm{R}=$ resistent)

Der Start der Inkubation der Bakterienkulturen erfolgte bei $t=0$ min. Die einzelnen ermittelten Messwerte der photometrischen Extinktion als Maß für die Keimzahl in der jeweiligen Wachstumsphase sind in Tabelle 5 zusammenfassend dargestellt. Das Bakterienwachstum als Funktion der Extinktion bei $\lambda=550 \mathrm{~nm}$ zur Inkubationszeit verdeutlichen die Abbildungen 3 und 4. Die mittlere logarithmische Wachstumsphase (in den Abbildungen durch die roten Markierungsbalken als Wendepunktbereiche der Funktionen gekennzeichnet) wird für die Stämme A22 und A3 nach 700 bis 800 min Wachstum unter den angegebenen Bedingungen bei einer Extinktion von 0,08-0,1 Einheiten erreicht. Der Beginn der Plateauphase des Wachstums wird nach cirka 950 min erreicht. 


\begin{tabular}{|l|l|l|}
\hline Inkubationszeit(min) & Extinktion (A3)OD 550 & Extinktion (A22) OD 550 \\
\hline 0 & 0 & 0 \\
\hline 210 & 0,001 & 0,003 \\
\hline 420 & 0,016 & 0,017 \\
\hline 580 & 0,039 & 0,033 \\
\hline 700 & 0,083 & 0,069 \\
\hline 825 & 0,142 & 0,116 \\
\hline 890 & 0,163 & 0,14 \\
\hline
\end{tabular}

Tabelle 5: Extinktionsbestimmung bei einer Wellenlänge von $\lambda=550 \mathrm{~nm}$

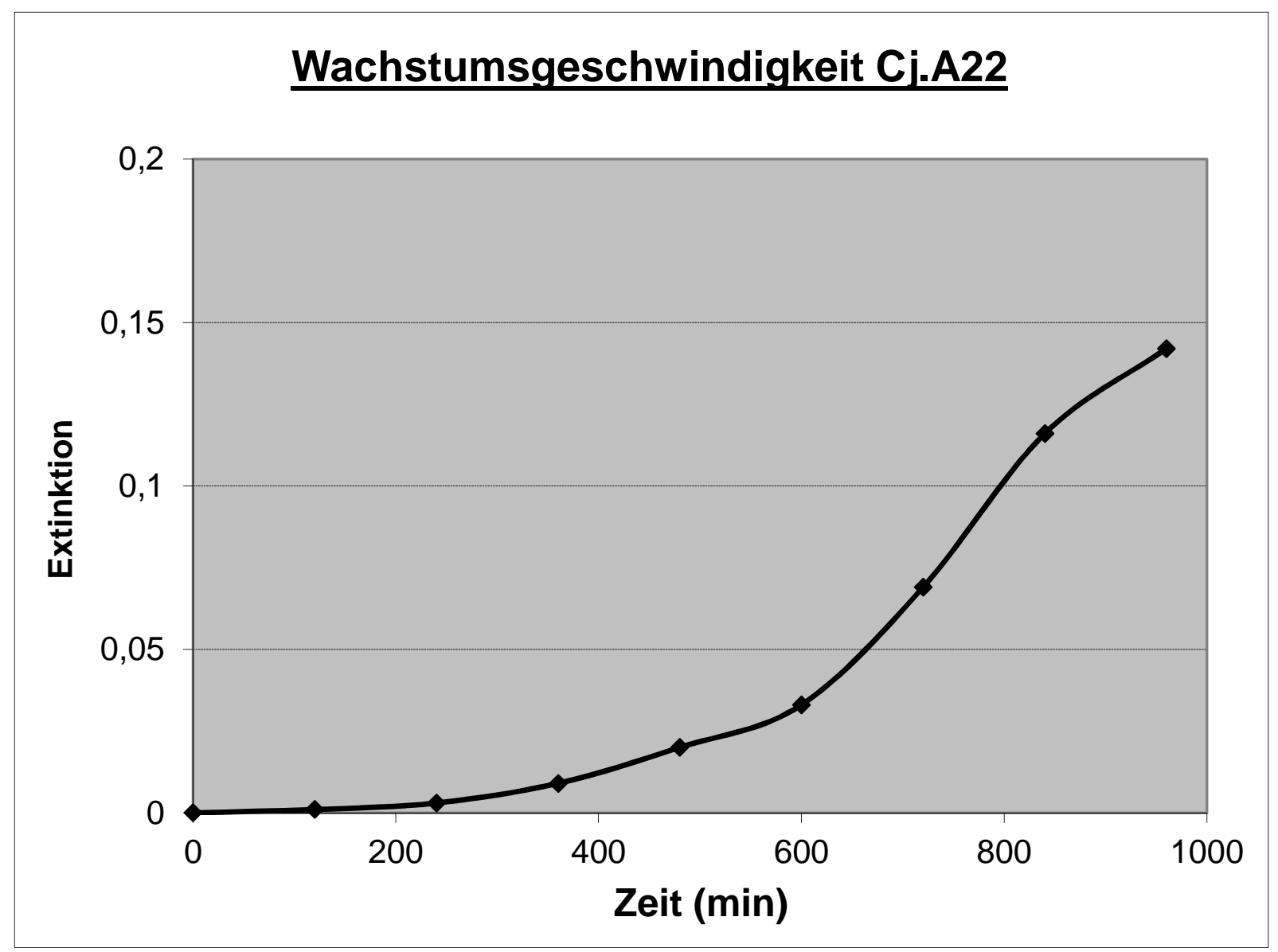

Abbildung 3:Wachstumskinetik des Wildtypstammes Cj. A22 


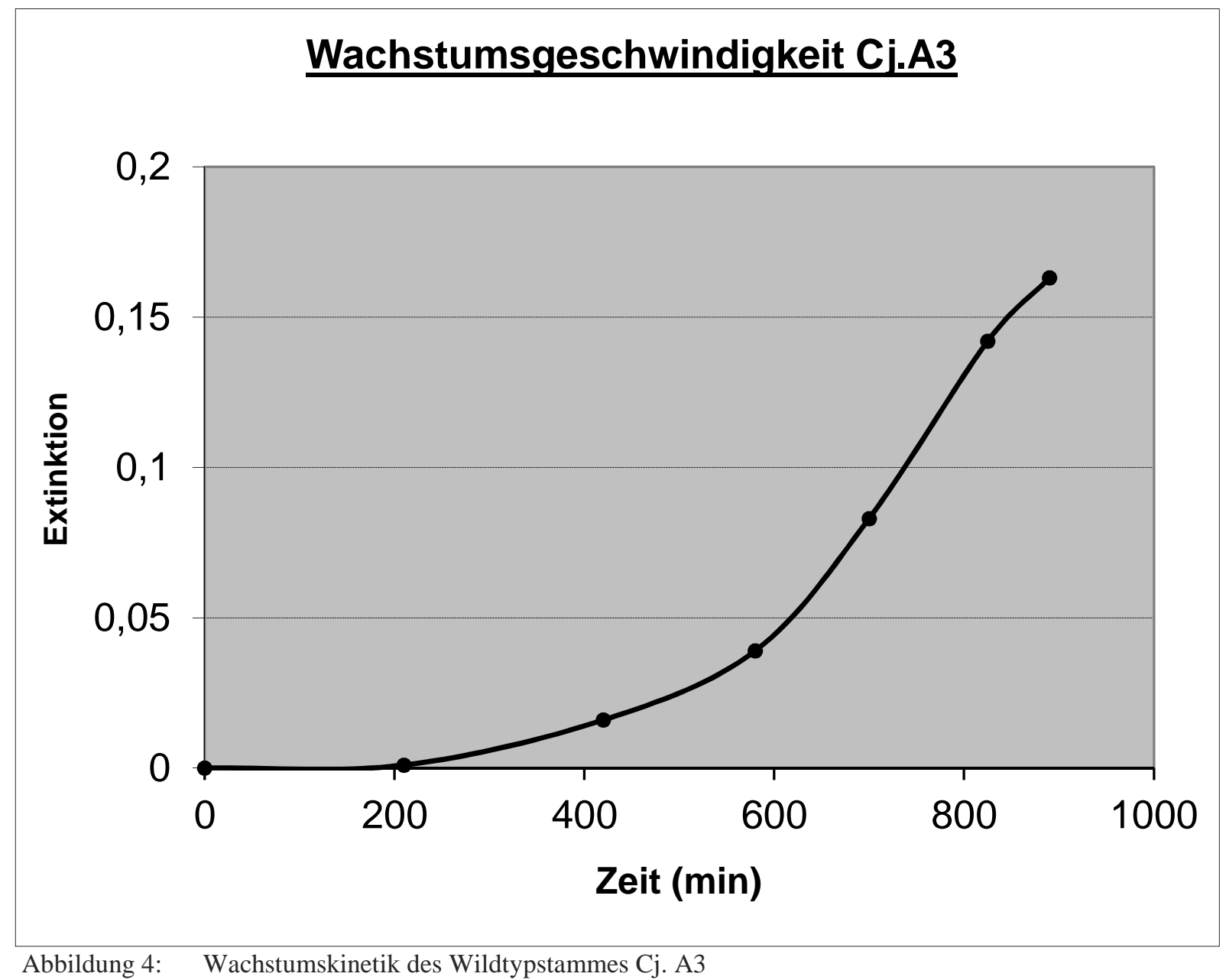

Abbildung 4: Wachstumskinetik des Wildtypstammes Cj. A3

\subsection{Genetische Manipulation der Bakterienstämme}

\subsubsection{Plasmidheilung}

Eine Plasmidheilung war trotz wiederholten Einsatzes verschiedener Methoden (vgl. Kapitel 2.2.4.1.) nicht möglich. Um dennoch dem Anspruch gerecht $\mathrm{zu}$ werden, isogene Paare klinischer Isolate im Zellkulturmodell vergleichen zu können, wurde auf den konjugativen Plasmidtransfer (vgl. Kapitel 2.2.4.4.) zurückgegriffen. 
Der Nachweis der Plasmidakquirierung nach Selektion der tetrazyklinresistenten Klone erfolgte qualitativ durch Plasmidpräparation, wie im Abschnitt Material und Methoden, Kapitel 2.2.4.5, beschrieben. Wie in Abbildung 5 dargestellt, tragen die transkonjugierten Varianten die Plasmide A9 (40,5 kB) bzw. A13 (41,4 kB). Der Wildtyp A22 besitzt ursprünglich ein $10 \mathrm{kB}$ großes Plasmid. Die darüber hinaus sichtbare Bande bei Stamm A22 und dessen Transkonjuganten resultiert aus dem Vorhandensein von Plasmid- DNA des $10 \mathrm{kB}$ großen Plasmids in der supercoiled-Form.

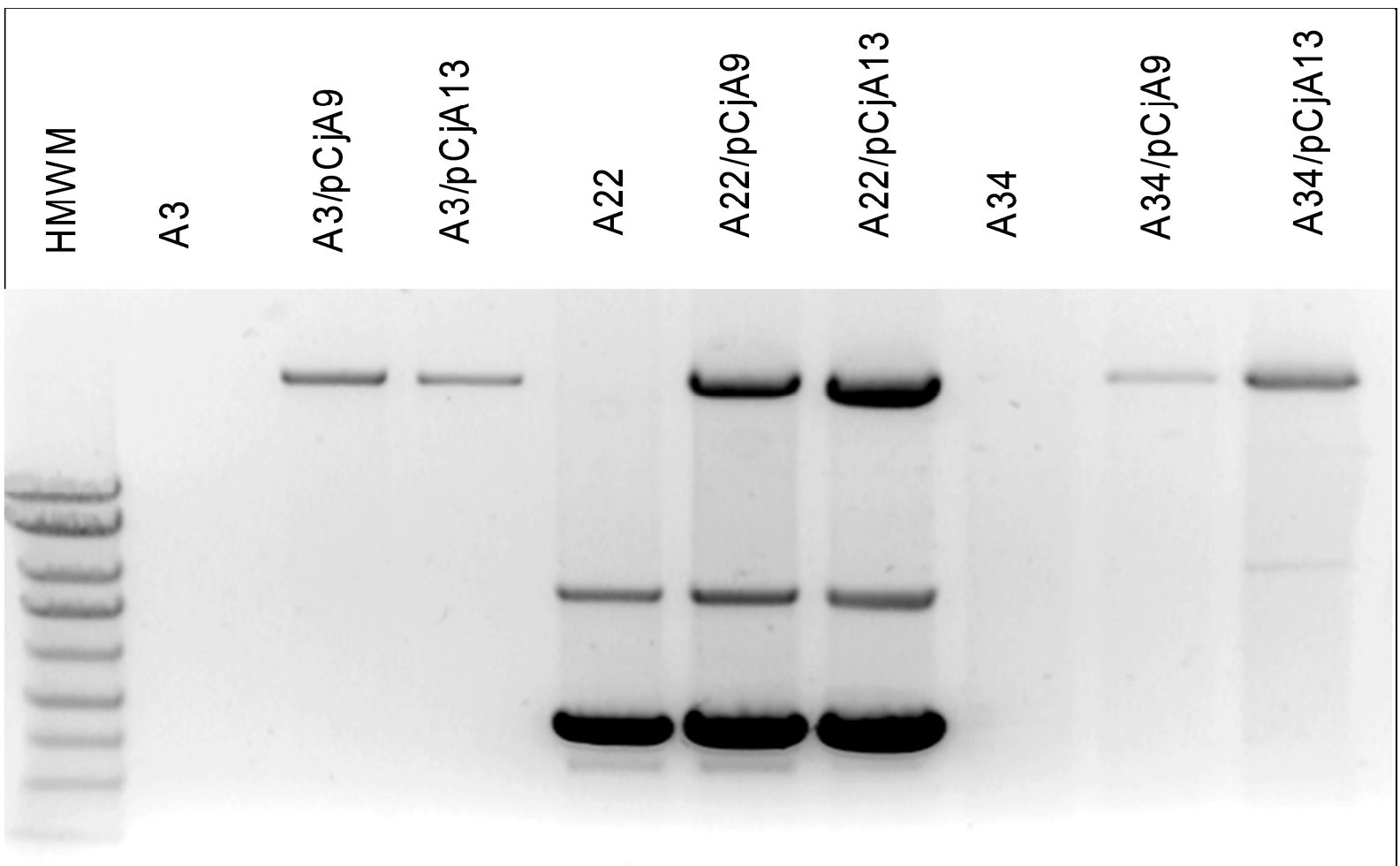

Abbildung 5: Plasmidpräparation der Wildtypstämme und der transkonjugierten Varianten

\subsubsection{Pulsfeldgelelektrophorese der Wildtypstämme und der Transkonjuganten}

Zusätzlich zur Darstellung der Plasmidaquirierung durch Plasmidpräparation (siehe Abbildung 5) wurde eine Pulsfeldgelelektrophorese durchgeführt. Abbildung 6 zeigt die Restriktionsprofile der Wildtypstämme A3, A22 und A34 sowie der durch Konjugation erzeugten Varianten $\mathrm{A} 3 \mathrm{pCjA} 9, \mathrm{~A} 3 \mathrm{pCjA} 13, \mathrm{~A} 22 \mathrm{pCjA} 9, \mathrm{~A} 22 \mathrm{pCjA} 13, \mathrm{~A} 34 \mathrm{pCjA} 9$ und A34pCjA13. Das Restriktionsmuster eines Wildtypstammes stimmte erwartungsgemäß mit 
dem der Transkonjuganten überein. Eine Veränderung der chromosomalen DNA während des Konjugationsversuches konnte somit weitgehend ausgeschlossen werden.

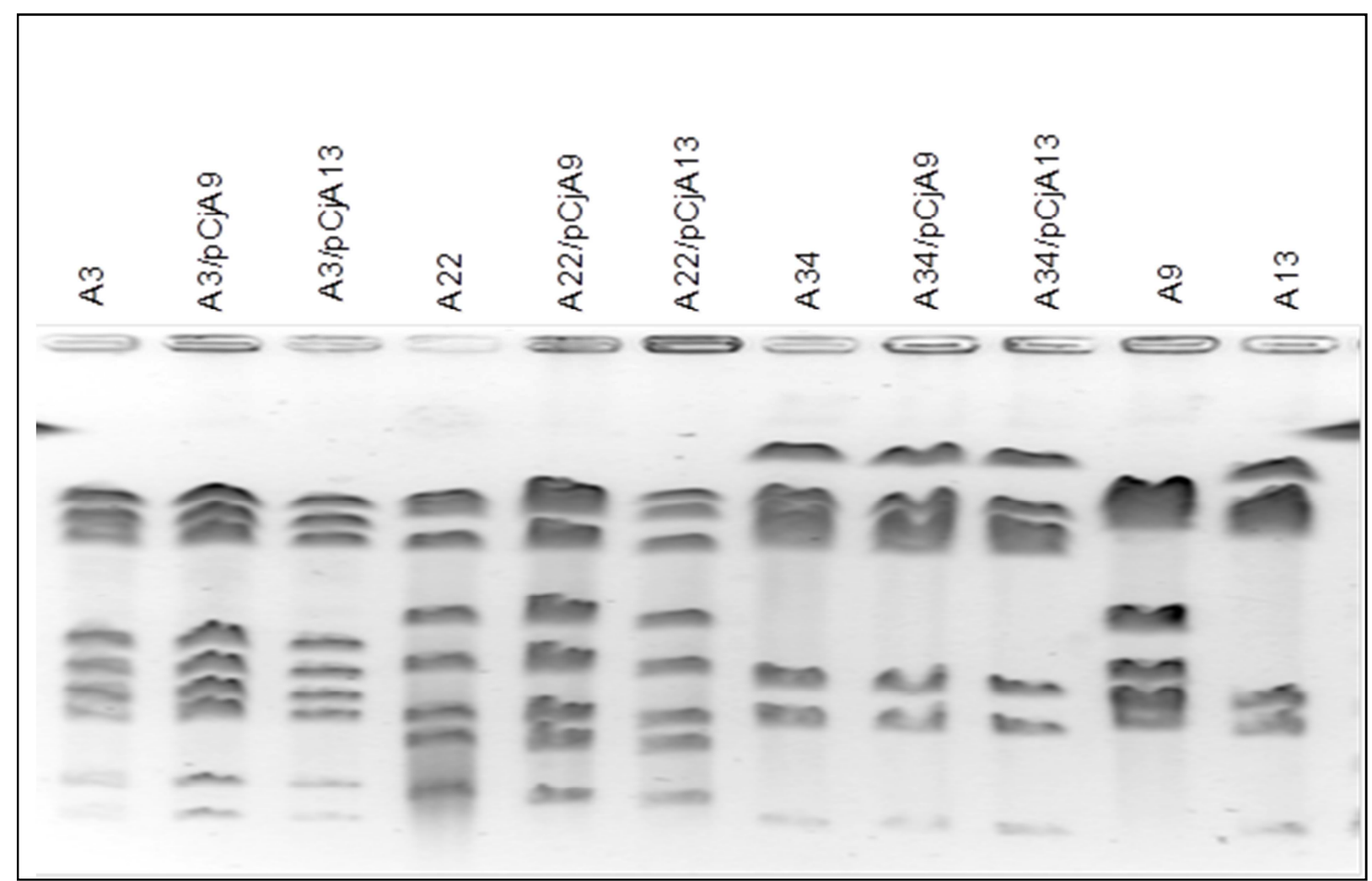

Abbildung 6: Pulsfeldgelelektrophorese der mittels des Enzyms Sma-I verdauten chromosomalen Bakterien-DNA der Rezipienten (A3, A22, A34), der Donatoren (A9, A13) sowie Konjuganten (A3pCjA9, A3pCjA13, A22pCjA9, A22pCjA13, A34pCjA9, A34pCjA13)

\subsection{Zustand der Zellmembranintegrität von humanen Caco2-Zellen nach Fixierung mit Paraformaldehyd}

Um eine vorzeitige Permeabilisierung der Caco2-Zellen durch die Fixierung mit Paraformaldehyd (PFA) auszuschließen, wurde, wie im Abschnitt Material und Methoden, Kapitel 2.2.5.2.2 beschrieben, eine Kontrolle unter Verwendung von anti-dsDNA-Antikörpern durchgeführt. Abbildung 7 zeigt die Immunfluoreszenzreaktion nach PFA-Fixierung bzw. nach Permeabilisierung der Zellen durch Methanol. Wie im Vergleich der beiden Bilder deutlich sichtbar, tritt durch alleinige PFA-Fixierung keine vorzeitige Permeabilisierung der Caco2-Zellmembranen auf. 


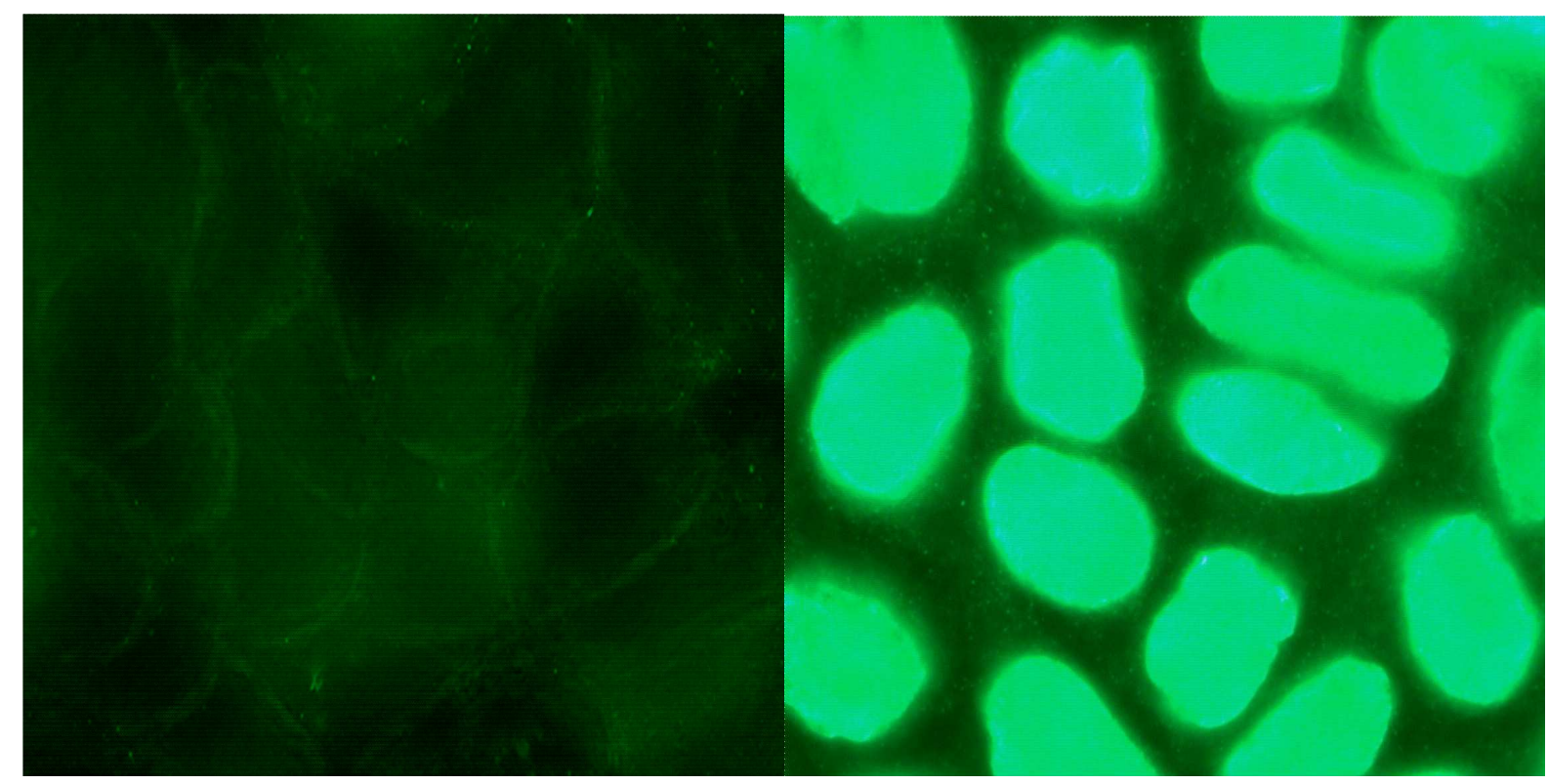

Abbildung 7: PFA-fixierte Caco2-Zellen zeigen nach Inkubation mit anti-dsDNA-Antikörpern keine spezifische Reaktion zwischen Antikörpern und Zell-DNA (links), während sich die Zell-DNA von Methanolpermeabilisierten Zellen mit anti-dsDNA-Antikörpern spezifisch markieren lässt (rechts).

\section{5}

\section{Gentamicin-Protektions-Assay (GPA)}

Da das Aminoglykosidantibiotikum Gentamicin die Zellmembran der Caco2- Zellen nicht penetriert, können extrazelluläre Bakterien mit diesem Antibiotikum selektiv abgetötet werden. Durch entsprechende Gestaltung des Versuchsablaufes in Kombination mit der Immunfluoreszenz (vgl. Kapitel 2.2.5.1) ist damit eine Bestimmung von intra- und extrazellulär lokalisierten Bakterien möglich.

Innerhalb eines Versuches wurde in Duplikaten getestet, die Auszählung der KBE durch Koloniezählung wurde in 2 Verdünnungsstufen vorgenommen, und alle Versuche wurden in mindestens 2 voneinander unabhängigen Vorgängen wiederholt. Die Infektionsdosen konnten durch die beschriebene photometrische Titrierung relativ konstant und damit vergleichbar gehalten werden und lagen bei allen Ansätzen zwischen $0,4 \times 10^{8}$ und $3 \times 10^{8}$ KBE. Abbildung 8 zeigt die graphische Darstellung der aus allen Versuchen gebildeten Mittelwerte der zellassoziierten Bakterien (intra- und extrazellulär) in logarithmischer Auftragung (auf die Darstellung der Standardabweichungen wurde aufgrund der geringen Anzahl von Einzelwerten verzichtet). Die Kontrollstämme, Salmonella Typhimurium (ATCC14028) und Escherichia coli DH5 $\alpha$ zeigten eine deutlich höhere Zellassoziation (Faktor10 für E. coli und Faktor 200 für S. Typhimurium) im Vergleich zu den getesteten Isolaten von C. jejuni. 
Eine signifikante Erhöhung der Zellassoziationsrate, welche sich auf die Plasmidaquirierung eines Wildtypstammes zurückführen ließe, ist jedoch nicht nachzuweisen.

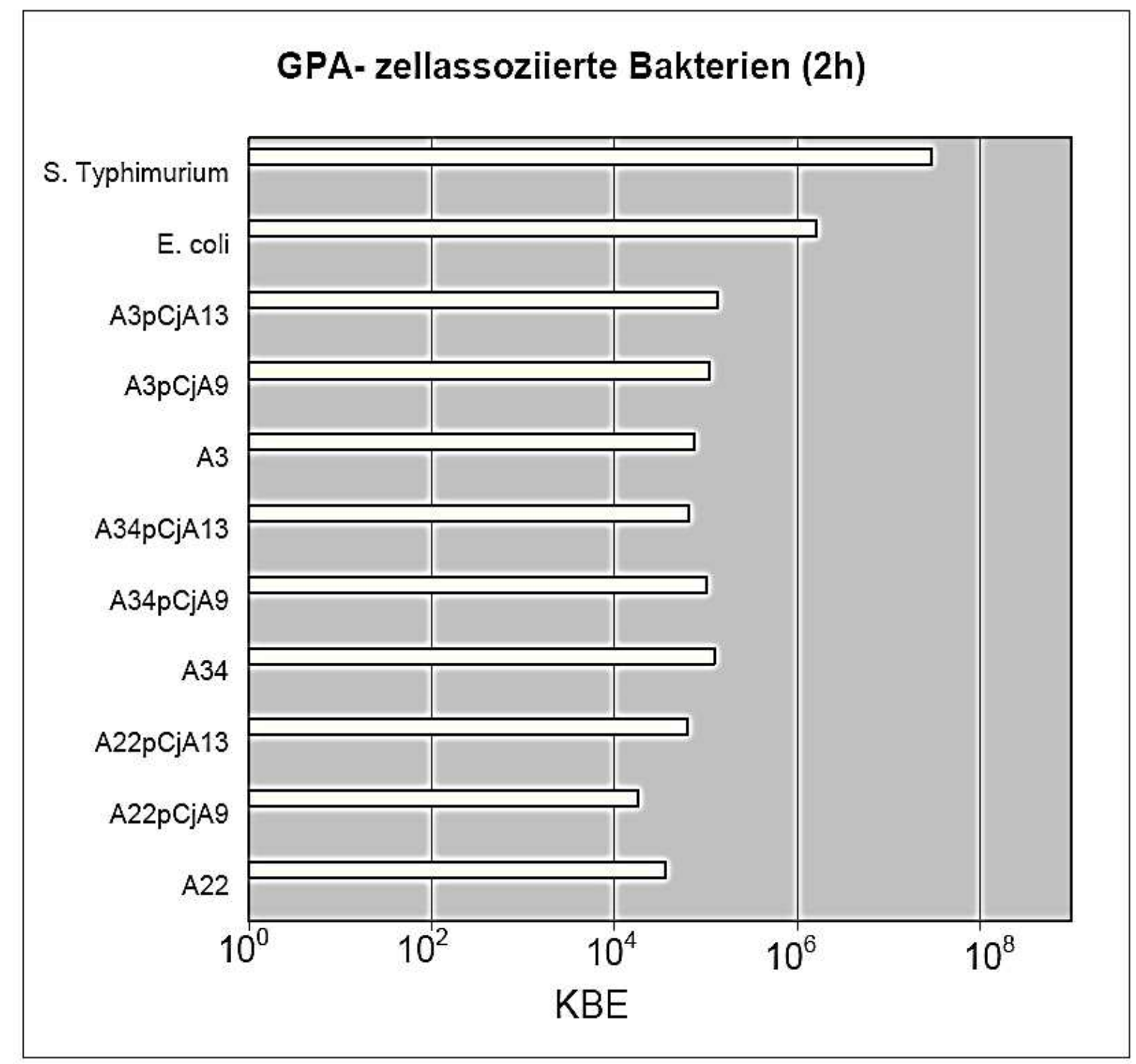

Abbildung 8: Semilogarithmische Darstellung der Zellassoziationen im GPA

Die Messung der Zellinvasion durch die untersuchten Wildtypstämme bzw. die Transkonjuganten erfolgte in analoger Weise. Dabei ergab sich erwartungsgemäß für die Positivkontrolle S. Typhimurium eine um den Faktor 10 höhere Invasionsrate im Vergleich zu den getesteten Campylobacter-jejuni-Isolaten. Der Wildtypstamm A22 sowie seine konjugierten Varianten wiesen im Vergleich zu den anderen beiden getesteten Isolaten eine niedrigere Invasionsrate auf. Im Vergleich der Wildtypstämme mit den transkonjugierten Varianten konnte auch hier kein signifikanter Unterschied nachgewiesen werden. Die 
Negativkontrolle E.coli DH5a zeigte erwartungsgemäß eine niedrige Invasionsrate. Die Graphiken in Abbildung 8 und Abbildung 9 geben die durchschnittlich im GPA gemessenen Raten für zellassoziierte Bakterien und ihre Invasion als Mittelwerte an.

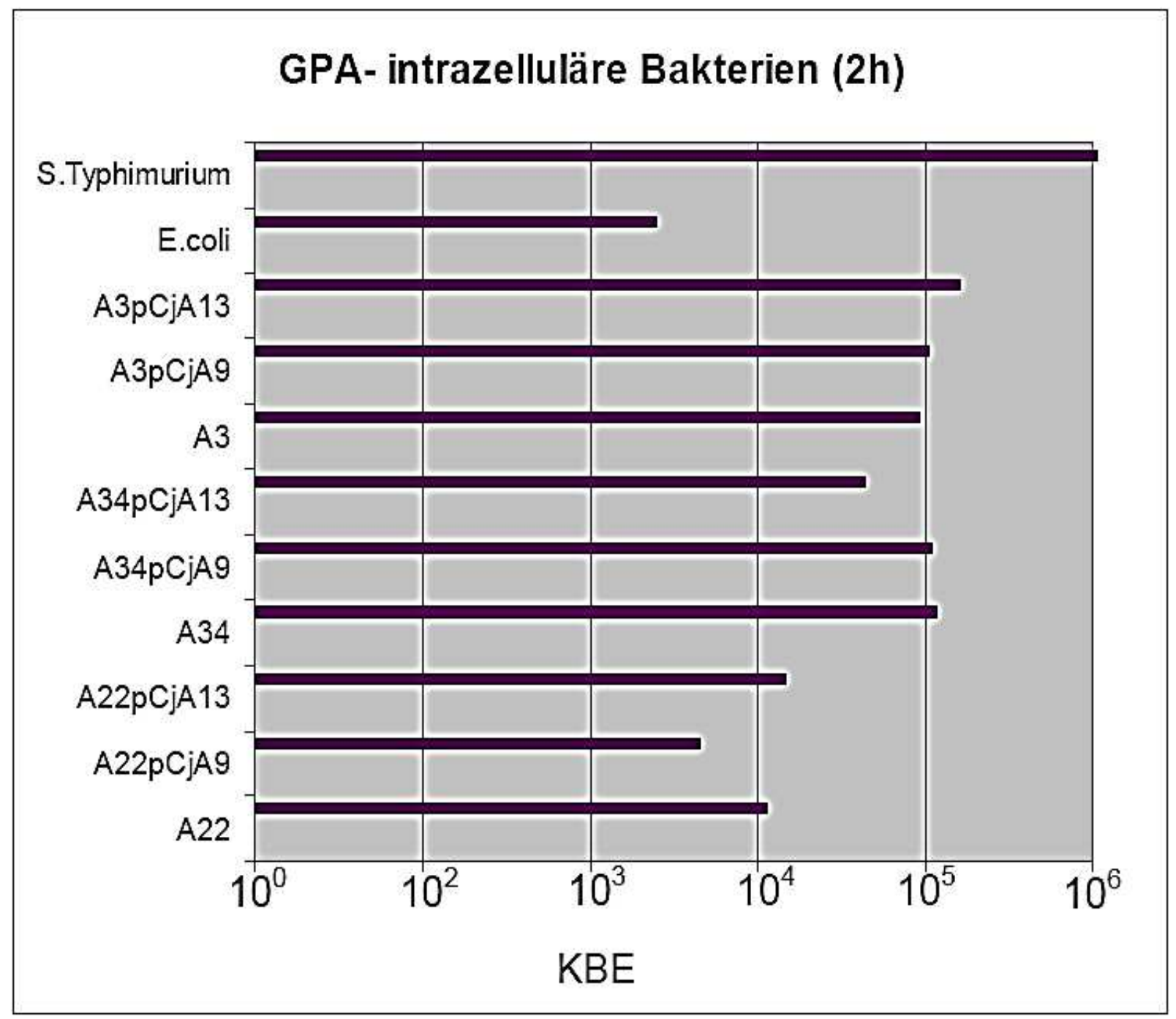

Abbildung 9: Zellinvasion, dargestellt in halblogarithmischer Form

Tabelle 6 zeigt im Überblick die Durchschnittswerte für die im GPA gemessenen Zellassoziations, -adhärenz und -invasionsraten. Angegeben sind die Absolutzahlen der für die entsprechenden Versuche gezählten KBE. Stammspezifische Abweichungen ergaben sich für A22 (und die entsprechenden Transkonjuganten) hinsichtlich der Zahl der relativen invasiven Keime (Anteil der intrazellulären Keime an der Gesamtzahl der intra- und extrazellulären Keime) mit einer etwa 5 fach niedrigeren relativen Invasionsrate im Vergleich zu A3 und A34. Die relative Invasionsrate wurde durch das Vorhandensein eines Plasmids nicht wesentlich beeinflusst. 


\begin{tabular}{|l|l|l|l|l|}
\hline & $\begin{array}{l}\text { intra- und extra- } \\
\text { zelluläre Bakterien }\end{array}$ & $\begin{array}{l}\text { intrazelluläre } \\
\text { Bakterien }\end{array}$ & $\begin{array}{l}\text { extrazelluläre, } \\
\text { adhärente Bakterien }\end{array}$ & $\begin{array}{l}\text { relative } \\
\text { Invasionsrate }\end{array}$ \\
\hline A3 & $7,5 \times 10^{4}$ & $9,2 \times 10^{3}$ & $6,6 \times 10^{4}$ & 12,3 \\
\hline A3pCjA9 & $1,1 \times 10^{5}$ & $1,0 \times 10^{4}$ & $1,0 \times 10^{5}$ & 9,1 \\
\hline A3pCjA13 & $1,3 \times 10^{5}$ & $1,6 \times 10^{4}$ & $1,2 \times 10^{5}$ & 12,3 \\
\hline A22 & $3,7 \times 10^{4}$ & $1,1 \times 10^{3}$ & $3,5 \times 10^{4}$ & 3,0 \\
\hline A22pCjA9 & $1,8 \times 10^{4}$ & $4,4 \times 10^{2}$ & $1,8 \times 10^{4}$ & 2,4 \\
\hline A22pCjA13 & $6,2 \times 10^{4}$ & $1,5 \times 10^{3}$ & $6,1 \times 10^{4}$ & 2,4 \\
\hline A34 & $1,2 \times 10^{5}$ & $1,2 \times 10^{4}$ & $1,1 \times 10^{5}$ & 10,0 \\
\hline A34pCjA9 & $1,0 \times 10^{5}$ & $1,1 \times 10^{4}$ & $9,3 \times 10^{4}$ & 11,0 \\
\hline A34pCjA13 & $6,3 \times 10^{4}$ & $4,3 \times 10^{3}$ & $6,0 \times 10^{4}$ & 6,8 \\
\hline
\end{tabular}

Tabelle 6: Durchschnittswerte für intra- und extrazelluläre Bakterien, Bakterien der Wildtypstämme A3, A34, A22 und deren Konjuganten im GPA.

\subsection{Indirekte Doppelimmunfluoreszenz}

Als Bestätigung des Gentamicin-Protektions-Assay diente die indirekte Doppelimmunfluoreszenz, die eine Bestimmung auf Einzelzellebene erlaubt. Die Auswertung der Invasions- und Adhärenzraten erfolgte durch Auszählung von mindestens 50 Gesichtsfeldern bei einer vierhundertfachen Vergrößerung am Mikroskop. Pro Gesichtsfeld wurde zunächst die Anzahl der Cy2-markierten Bakterien (grün = extra- und intrazellulär) und anschließend im selben Gesichtsfeld nach Filterwechsel die Anzahl der zusätzlich TRITC-markierten Bakterien (rot = nur extrazellulär) in allen beurteilbaren Raumebenen ermittelt. Nach vollständiger Auszählung eines Bakterienstammes wurde die gemessene Invasionsrate pro 100 beurteilter Caco2- Zellen nach folgender Formel ermittelt:

\section{(1) $\mathrm{K}_{\mathrm{Inv}(100)}=\left(\mathrm{K}_{\mathrm{Cy} 2}-\mathrm{K}_{\mathrm{TRITC}} / \mathrm{N}_{\mathrm{Cac02}} \bullet \mathrm{N}_{\mathrm{G}}\right) \cdot 100$}

$\mathrm{K}_{\text {Inv }(100)} \quad: \quad$ invasive Keime pro 100 Caco2-Zellen

$\mathrm{K}_{\mathrm{Cy2}} \quad$ : $\quad$ CY2 -markierte Bakterien (grünfluoreszierend =extra-und intrazellulär) 


$\begin{array}{lll}\mathrm{K}_{\text {Tritc }} & : & \text { TRITC-markierte Bakterien (rotfluoreszierend = nur extrazellulär) } \\ \mathrm{K}_{\mathrm{Cy2}-\mathrm{K}_{\text {TRITC }}} & : & \text { entspricht den intrazellulären Bakterien } \\ \mathrm{N}_{\mathrm{Caco2}} & : & \text { durchschnitliche Anzahl der Caco2-Zellen pro Gesichtsfeld } \\ \mathrm{N}_{\mathrm{G}} & : & \text { Anzahl der in einem Versuch ausgewerteten Gesichtsfelder }\end{array}$

Der Wert $\mathrm{N}_{\mathrm{Caco} 2}$ wurde bestimmt, indem die durchschnittliche Anzahl an Caco2-Zellen pro Gesichtsfeld in 10 repräsentativen Gesichtsfeldern ausgezählt wurde. $\mathrm{N}_{\mathrm{Caco} 2}$ wurde bei allen Berechnungen als Konstante mit 123 Caco2-Zellen pro Gesichtsfeld verwendet.

Die Adhärenzraten wurden analog dazu mit folgender Formel bestimmt:

(2) $\mathrm{K}_{\mathrm{Adh}(100)}=\left(\mathrm{K}_{\mathrm{TRITC}} / \mathrm{N}_{\mathrm{Cac02}} \cdot \mathrm{N}_{\mathrm{G}}\right) \cdot 100$

Die Mittelwerte für $\mathrm{K}_{\mathrm{Adh}(100)}$ und $\mathrm{K}_{\operatorname{Inv}(100)}$ sowie die durch Ausplattierung ermittelten Infektionsdosen sind in Tabelle 7 und Tabelle 8 dargestellt. Das Experiment wurde in vier unabhängig voneinander durchgeführten Versuchen wiederholt. Die graphische Darstellung erfolgt in den Abbildungen 10 und 11.

Die MOI (multiplicity of infection) als das relative Verhältnis von Infektionsdosis zu Caco2Zellen beträgt im oben dargestellten Versuchsablauf 2500 (die durchschnittliche Anzahl der Caco2-Zellen pro Glasplättchen betrug etwa 200.000-250.000 Zellen). Transkonjuganten

Getestet wurden die Isolate A22 und A34 jeweils mit den konjugierten plasmidhaltigen Varianten über eine Inkubationzeit von $2 \mathrm{~h}$. Das Isolat A3, sowie seine konjugierten Varianten ließen sich nicht erfolgreich durch Antikörper markieren. Die Experimente wurden für A34 viermal, für A22 zweimal wiederholt. Die Abbildungen 10 und 11 zeigen eine graphische Darstellung der Versuchswerte. Auf die Berechnung von Standardabweichungen wurde im Fall von A22 aufgrund der geringen Menge an Einzeldaten verzichtet. Die Adhärenzraten wurden für die getesteten klinischen Isolate A22 und A34 sowie deren plasmidhaltigen Varianten $\mathrm{A} 22 \mathrm{pCjA} 9, \mathrm{~A} 22 \mathrm{pCjA} 13, \mathrm{~A} 34 \mathrm{pCjA} 9$ und $\mathrm{A} 34 \mathrm{pCjA} 13$ bei nur geringer versuchsbedingter Variabilität zwischen 2-3 Keimen/100 Caco2- Zellen ermittelt. Die 
durchschnittlichen Invasionsraten betrugen zirka 10 invasive Keime/100 Caco2- Zellen. Eine signifikante Veränderung von Invasion und Adhärenz der getesteten Bakterienstämme durch die Plasmidaquirierung war nicht nachweisbar.

\begin{tabular}{|l|l|l|l|}
\hline Stamm & A22 & A22pCjA9 & A22pCjA13 \\
\hline $\mathrm{K}_{\text {Inv(100) }}$ & 9,1 & 6,9 & 7,5 \\
\hline $\mathrm{K}_{\text {Adh(100) }}$ & 2,5 & 3,4 & 2,9 \\
\hline Infektionsdosis & $2,5 \times 10^{9}$ & $3 \times 10^{9}$ & $3,7 \times 10^{9}$ \\
\hline
\end{tabular}

Tabelle 7: Invasion und Adhärenz für den Stamm A22 und seine Varianten

\begin{tabular}{|l|l|l|l|}
\hline Stamm & A34 & A34pCjA9 & A34pCjA13 \\
\hline $\mathrm{K}_{\text {Inv(100) }}$ & 8,9 & 7,3 & 8,4 \\
\hline $\mathrm{K}_{\text {Adh(100) }}$ & 2,2 & 2,3 & 2,7 \\
\hline Infektionsdosis & $1,7 \times 10^{9}$ & $3,5 \times 10^{8}$ & $5,6 \times 10^{8}$ \\
\hline
\end{tabular}

Tabelle 8: Invasion und Adhärenz für den Stamm A34 und seine Varianten 


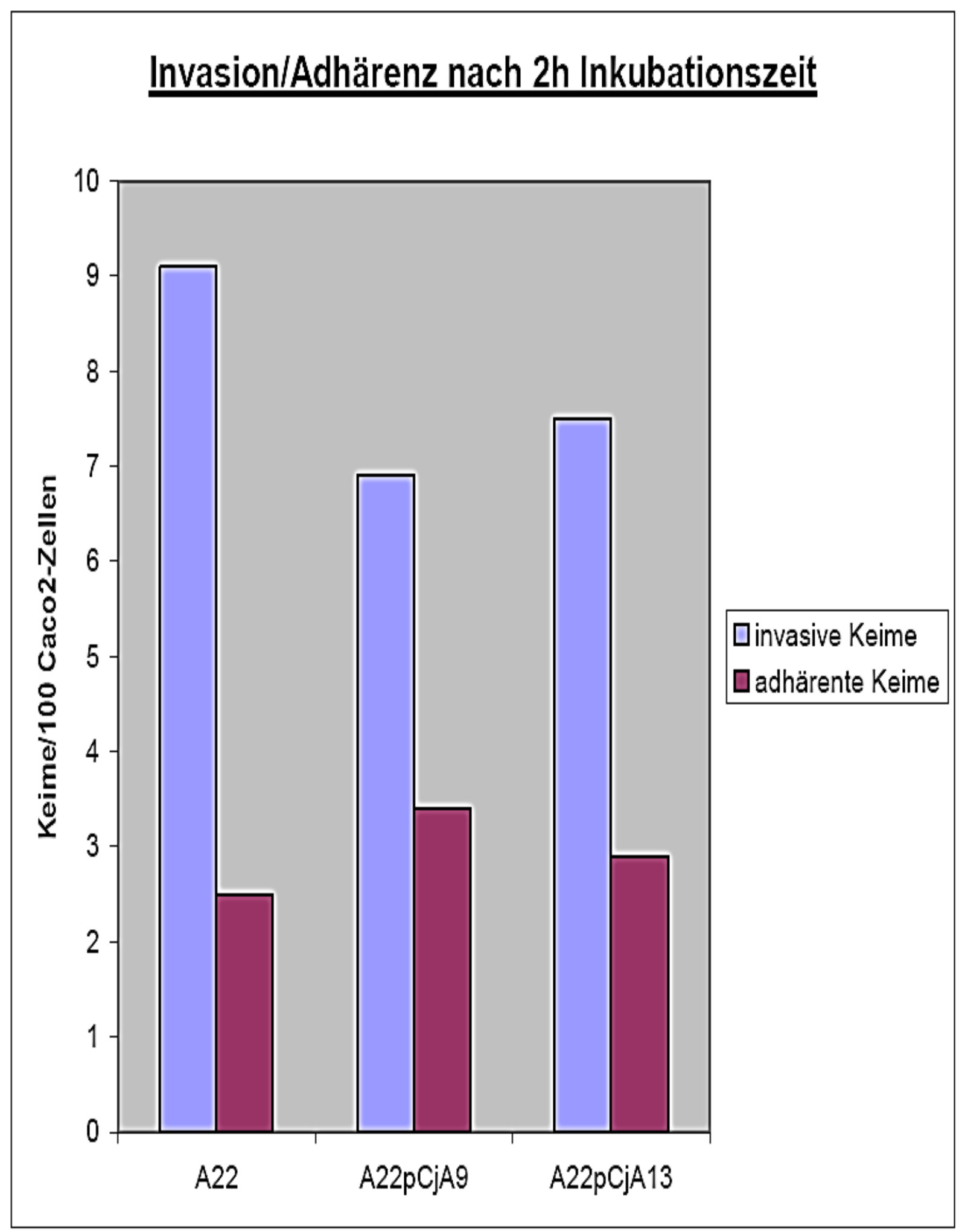

Abbildung 10: Invasion und Adhärenz des Wildtypstammes A22 und der beiden transkonjugierten Varianten A22 pCjA9 und A22pCjA13 im Vergleich. 


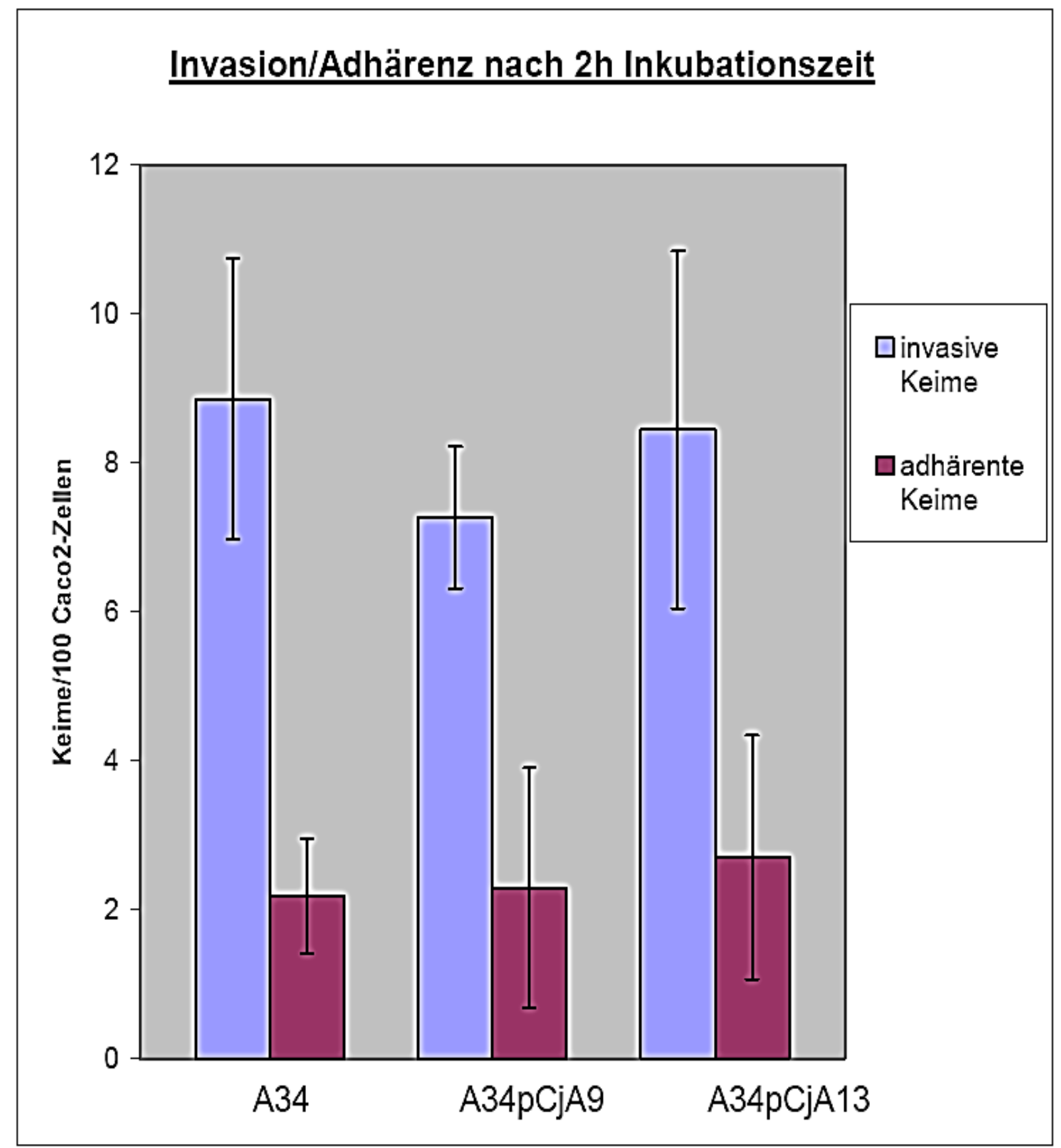

Abbildung 11: Invasion und Adhärenz des Wildtypstammes A34 und der beiden transkonjugierten Varianten A34pCjA9 und A34pCjA13 im Vergleich

Die Abbildung 12 zeigt exemplarisch einen typischen Bildausschnitt des mikroskopischen Ergebnisses nach Immunfluoreszenzmarkierung am Beispiel der hier dargestellten Bakterien des Stammes CjA34. Das mit rotem Pfeil markierte Bakterium links (mit deutlich sichtbarer Begeißelung) liegt intrazellulär und kommt deshalb rechts im identischen Bildausschnitt (nach TRITC-Markierung) nicht zur Darstellung. 

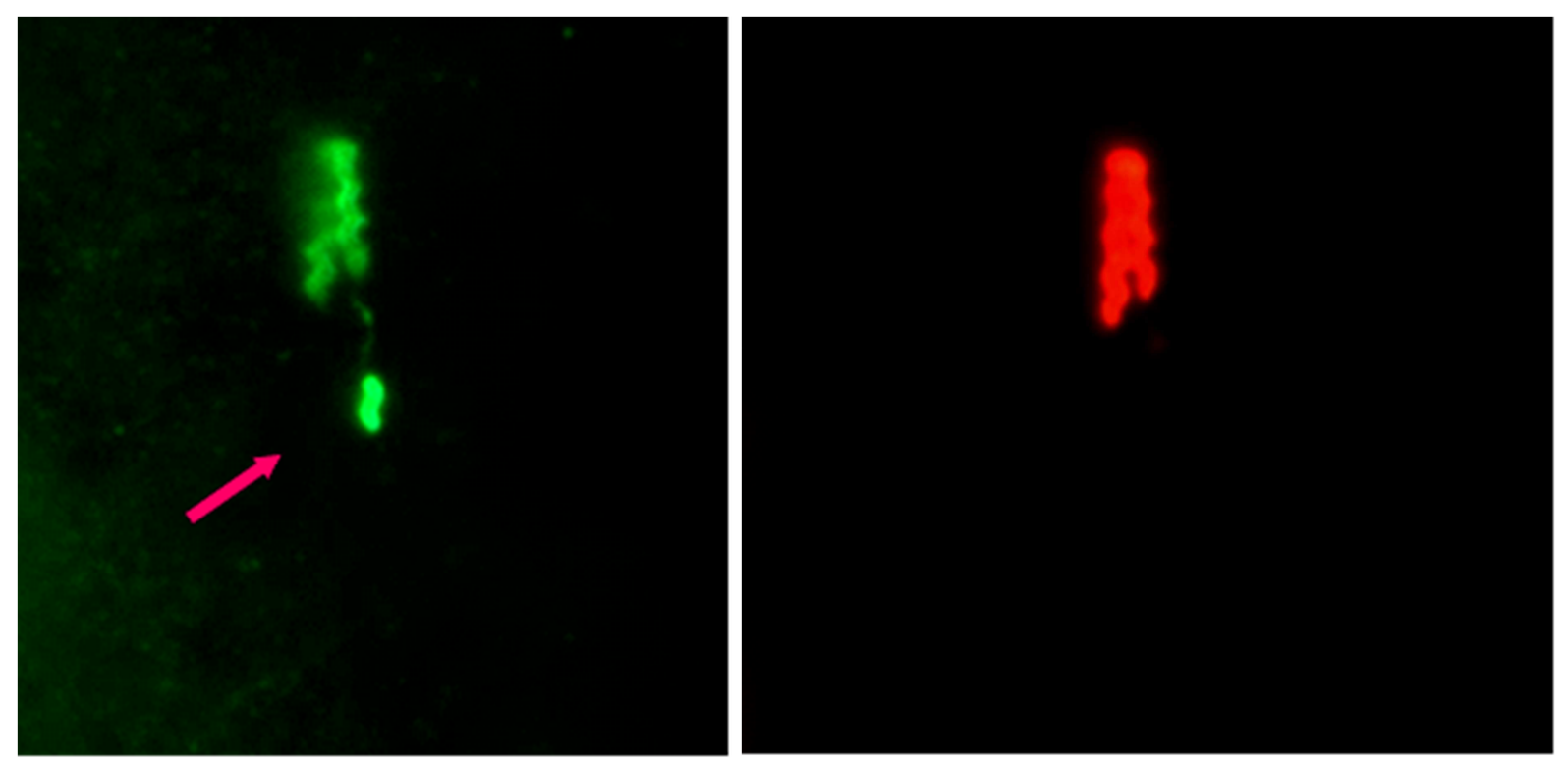

Abbildung 12: Mit Hilfe der indirekten Doppelimmunfluoreszenz werden extra- und intrazelluläre Bakterien grün (links Cy2-markiert) und streng extrazellulär lokalisierte Bakterien rot (rechts, TRITC-markiert) dargestellt..

Als Vergleichskontrolle $\mathrm{zu}$ den getesteten $C$. jejuni Wildtypstämmen und ihren transkonjuganten Varianten wurde eine Reihe weiterer Bakterien in analoger Weise hinsichtlich ihrer Fähigkeit zur Invasion und Adhärenz im Zellkulturmodell untersucht. Der als invasiv geltende Salmonella-Typhimurium-Stamm (ATCC 14028) diente als Positivkontrolle, der nichtinvasive E. coli- Stamm (DH5 $\alpha$ ) als Negativkontrolle. Des Weiteren wurde der C. jejuni- Referenzstamm NCTC 81-176, sowie ein aus einem Huhn isolierter Stamm verwendet. Ein weiteres bovines $C$. jejuni-Isolat, mit welchem Caco2-Zellen infiziert wurden, konnte nicht erfolgreich durch die Antikörper markiert werden und entzog sich so der Auswertung. Abbildung 13 stellt die Ergebnisse der Kontrollgruppe graphisch dar. Der Salmonellenstamm zeigte eine, im Vergleich zu C. jejuni-Stämmen, fast 10-fach höhere Invasionsrate. E. coli-DH5a besaß praktisch keine Fähigkeit zur Zellinvasion. Die Zellinvasionsraten für NCTC 81-176 und das Hühnerisolat liegen bei 8 bzw. 5 invasiven Bakterien pro 100 Caco2-Zellen und sind damit mit den zuvor getesten Bakterienstämmen von $C$. jejuni vergleichbar. 


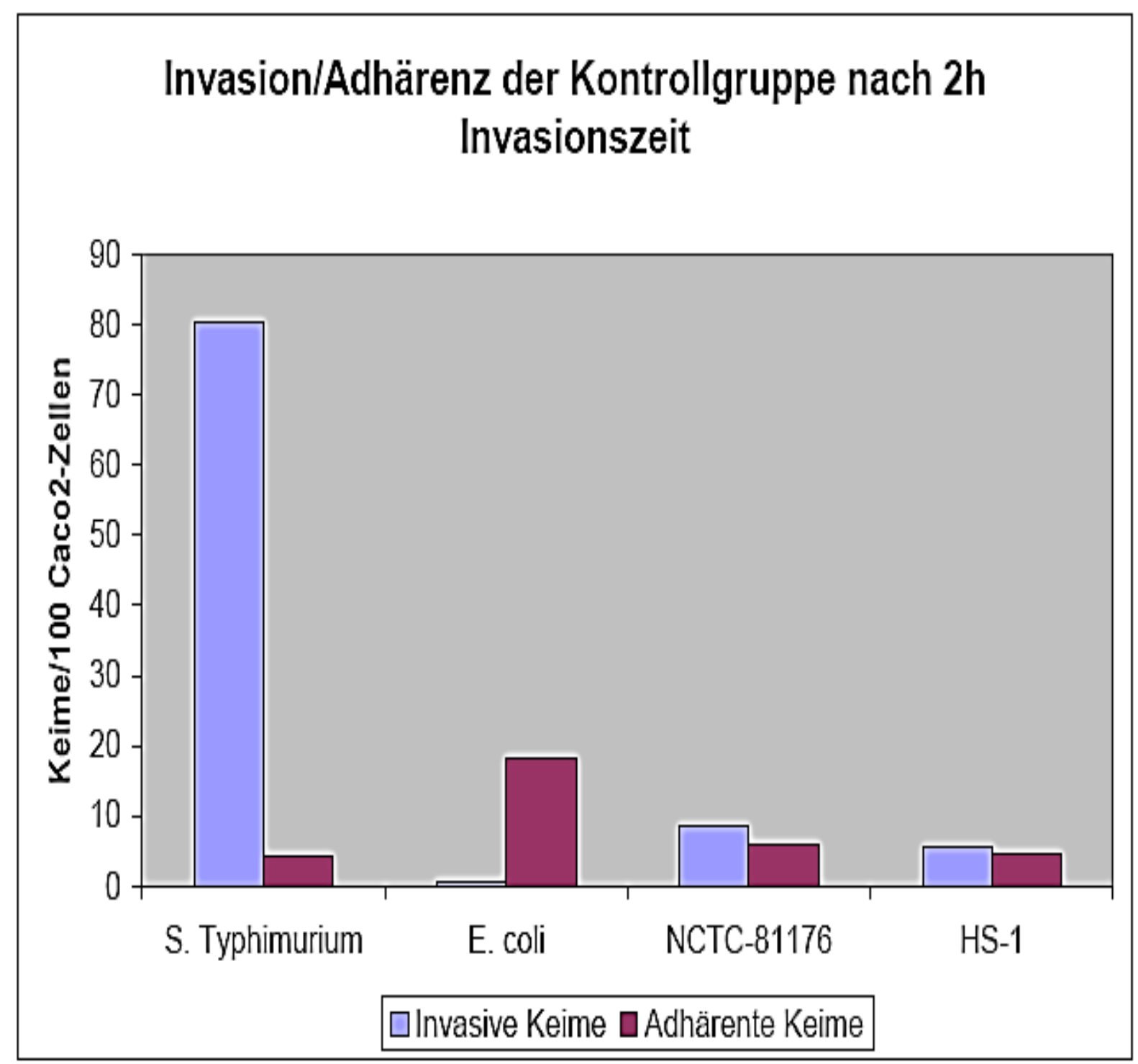

Abbildung 13: Invasion und Adhärenz nach 2h Invasionszeit in der Kontrollgruppe

In den Abbildungen 14 und 15 sind die Bakterien des Stammes E. coli DH5a dargestellt. Morphologisch deutlich sichtbare Unterschiede $\mathrm{zu}$ C. jejuni liegen in der fehlenden Begeißelung, sowie ihrer stäbchenförmigen Morphologie. Eine spiralige Windung fehlt hier. Aufgrund der fehlenden Eigenschaft der verwendeten E. coli Bakterien in Caco2-Zellen zu invadieren, können die Bakterien von beiden Antikörpern markiert werden und sind somit extrazellulär lokalisiert.

Abbildung 16 verdeutlicht die Untersuchungsergebnisse im Immunfluoreszenzversuch bei der positiven Invasionskontrolle Salmonella Typhimurium. Alle im gewählten Gesichtsfeldausschnitt sichtbaren Keime erscheinen nur als Cy2-positives Fluoreszenzmuster und werden durch die TRITC-Antikörper nicht markiert, was als Beweis für ihre intrazelluläre Lokalisation bewertet werden kann. 


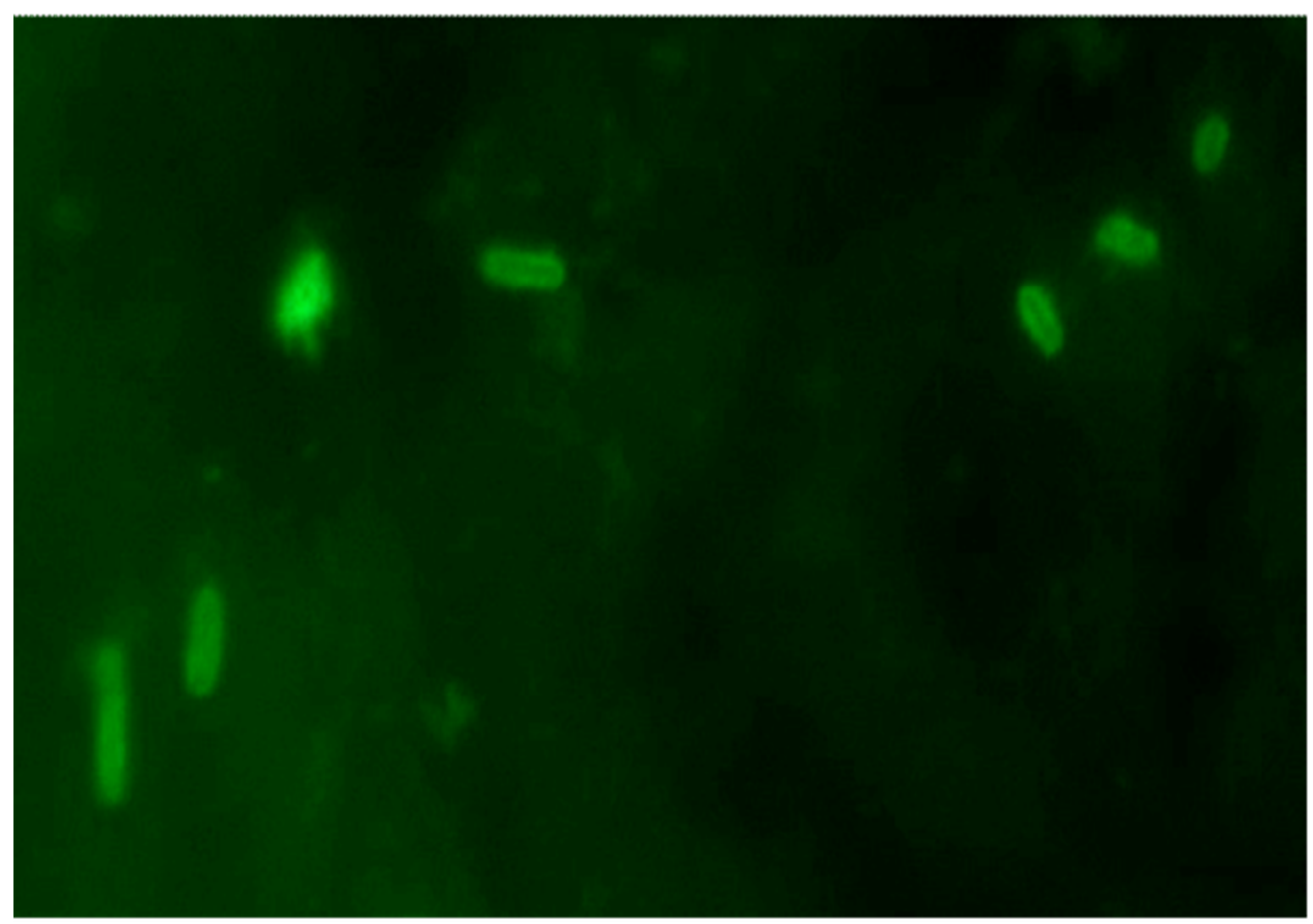

Abbildung 14: E. coli DH5a, zellassoziierte Keime, Cy2-markiert

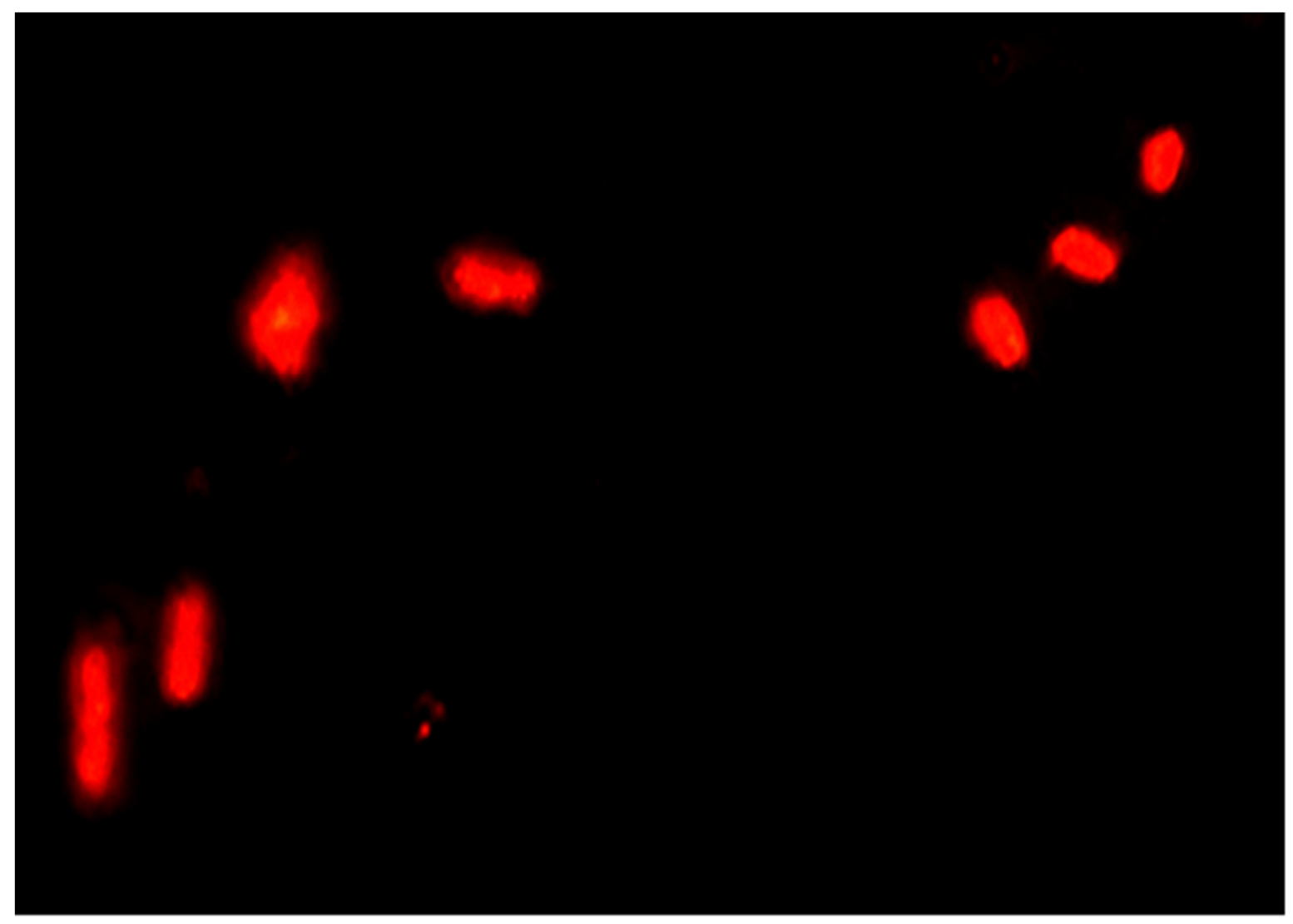

Abbildung 15: E. coli DH5 $\alpha$, extrazelluläre Keime, TRITC-markiert 


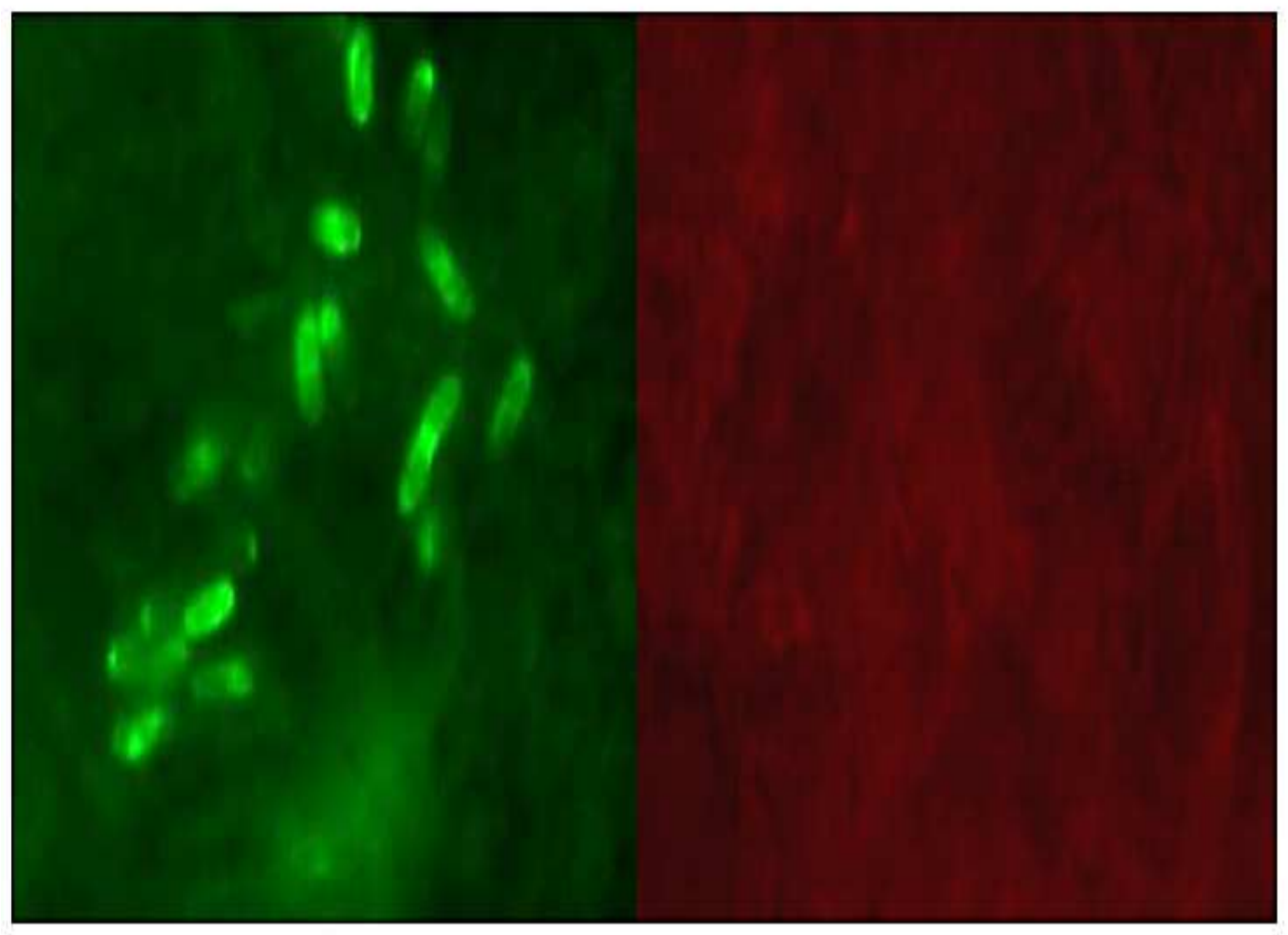

Abbildung 16: Salmonella Typhimurium Cy2- bzw. TRITC-markiert

Für den Wildtypstamm A34 sowie seine konjugierten Varianten A34pCjA9 und A34pCjA13 wurde der zeitliche Verlauf der Invasion und Adhärenz unter sonst gleich bleibenden Bedingungen, wie in Kapitel 2.2.5.5 beschrieben, bestimmt. Die Experimente wurden zweimal wiederholt, die Mittelwerte für die Invasions- und Adhärenzraten der einzelnen Bakterienstämme $\mathrm{zu}$ den Zeitpunkten $15 \mathrm{~min}, 60 \mathrm{~min}, 120 \mathrm{~min}$ sind in Tabelle 9 zusammengefasst. Die graphische Darstellung ist der Abbildung $17 \mathrm{zu}$ entnehmen. Auf die Angabe von Standardabweichungen wurde aufgrund der geringen Anzahl an Einzelwerten verzichtet. Die einzelnen Werte sind in Tabelle 9 in Klammern angegeben.

Die Adhärenzraten unterschieden sich über den beobachteten Zeitraum weder im Vergleich der gemessenen Zeitpunkte, noch im Vergleich von Wildtypstamm zu den konjugierten Varianten signifikant voneinander. Die Invasionsraten der Bakterienstämme zeigen eine deutliche zeitliche Varianz mit einem Maximum an invasiven Keimen zum Zeitpunkt $\mathrm{t}=15$ min, im weiteren Verlauf ist eine deutliche Reduktion der Anzahl der invasiven Bakterien, mit 
einem Minimum zum Zeitpunkt t=120 min zu verzeichnen. Dieser Effekt wurde sowohl beim Wildtypstamm A34, als auch bei den beiden transkonjugierten Varianten A34pCjA9 und A34 pCjA13 beobachtet und scheint damit unabhängig von der Präsenz eines Plasmids zu sein. Die Werte für Invasion und Adhärenz nach 120 min sind vergleichbar mit den bereits ermittelten Daten der Einzelexperimente (vgl. Kapitel 3.6).

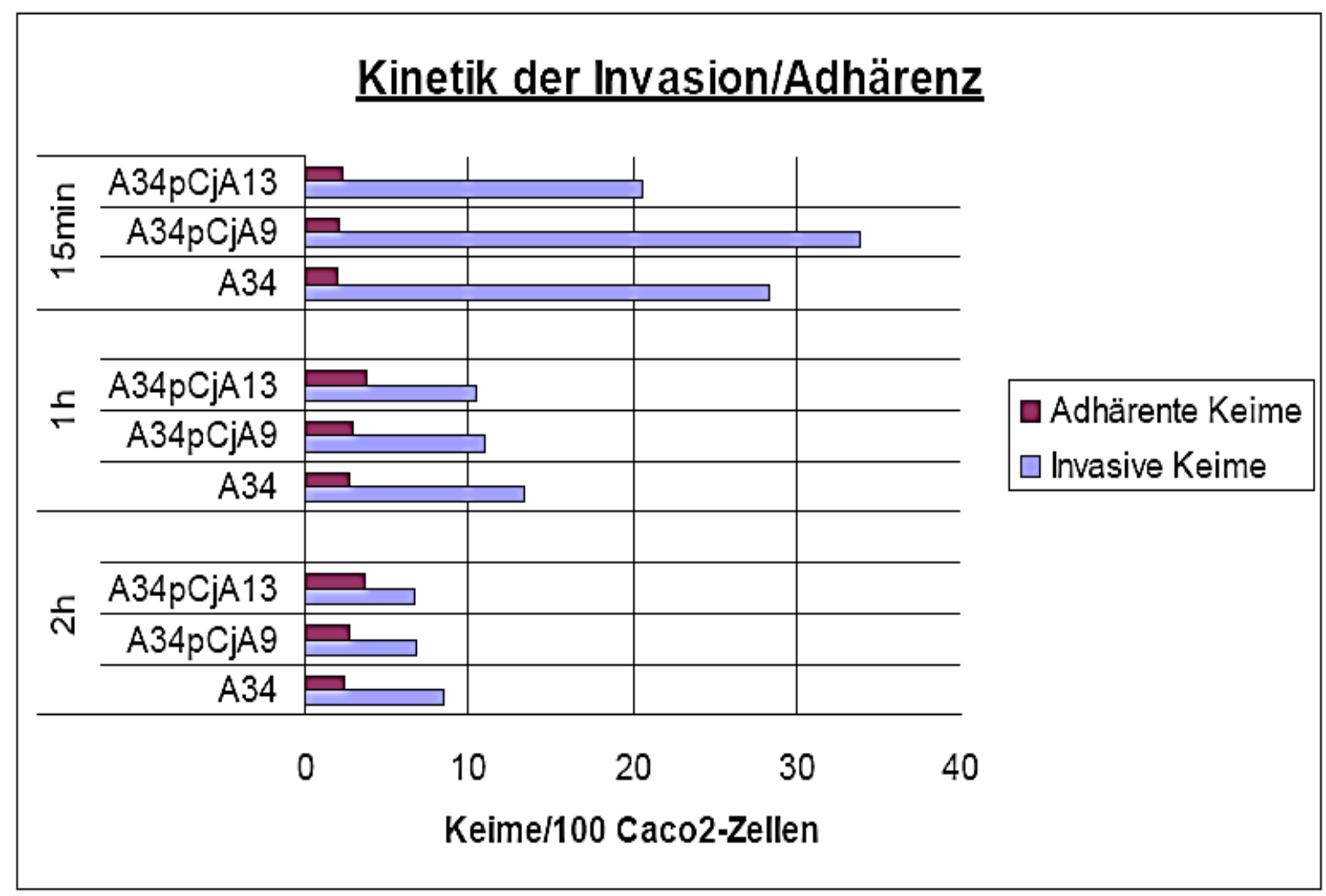

Abbildung 17: Invasion und Adhärenz der Wildtypstämme und ihrer transkonjuganten Varianten im zeitlichen Verlauf

\begin{tabular}{|l|l|l|l|}
\hline Zeitpunkt & Stamm & Invasive Keime & Adhärente Keime \\
\hline & A34 & $28,2(18,4-38,0)$ & $2,0(1,7-2,3)$ \\
\hline $15 \mathrm{~min}$ & A34pCjA9 & $33,8(30,1-37,5)$ & $2,2(1,4-2,9)$ \\
\hline & A34pCjA13 & $20,4(14,8-26,0)$ & $2,3(1,8-2,7)$ \\
\hline & & & \\
\hline & A34 & $13,4(13,0-13,8)$ & $2,8(2,2-3,4)$ \\
\hline & A34pCjA9 & $10,9(10,2-11,6)$ & $2,9(0,9-4,9)$ \\
\hline & A34pCjA13 & $10,5(10,4-10,5)$ & $3,8(1,3-6,3)$ \\
\hline & & & \\
\hline $120 \mathrm{~min}$ & A34 & $8,5(6,4-10,5)$ & $2,5(1,8-3,2)$ \\
\hline & A34pCjA9 & $6,8(5,8-7,7)$ & $2,8(1,0-4,6)$ \\
\hline & A34pCjA13 & $6,8(5,4-8,1)$ & $3,7(2,3-5,1)$ \\
\hline
\end{tabular}

Tabelle 9:Mittelwerte der Adhärenz- und Invasionsraten zu drei verschiedenen Zeitpunkten (in Klammern sind die Einzelwerte angegeben.) 


\section{DISKUSSION}

Bakterien der Spezies C. jejuni nehmen aus infektionsepidemiologischer Sicht eine wichtige Stellung unter den bakteriell hervorgerufenen Enterititiden ein. Sie gelten weltweit neben Salmonellen als häufigste Ursache bakterieller Darminfektionen (RKI 2011). Die gehäuft in den Sommer- und Herbstmonaten auftretende Campylobakteriose äußert sich durch Abdominalschmerzen mit begleitenden breiigen bis wässrigen Stuhlgängen. Die Erregertransmission erfolgt über kontaminierte tierische Fleisch- oder Milchprodukte. Reaktive Arthritiden und das Guillain-Barré-Syndrom sind mit Infektionen durch C. jejuni assoziiert (Altekruse et al. 1999, Nachamkin et al. 1998, Rhodes 1982, Vucic et al 2009). Eine systematische Metaanalyse aus 32 Studien zwischen 1982 und 2010 konnte in 31\% der dokumentierten GBS-Fälle einen ursächlichen Zusammenhang zu einer C..jejuni -Infektion herstellen (Poropatich et al. 2010). In Tiermodellen gelang es in jüngster Vergangenheit, molekulares Mimikry zwischen Bestandteilen der Bakterienoberfläche und Bestandteilen neuronaler Strukturen als entscheidenden Pathomechanismus zu beweisen (Shahrizaila und Yuki 2011).

In den vergangen Jahrzehnten ist es gelungen, wichtige Virulenzfaktoren von darmpathogenen Bakterien anderer Spezies genauer zu charakterisieren (Hueck 1998). Die entsprechenden Pathogenitätsmechanismen sind zum Teil sehr detailliert beschrieben. Dabei wird eine Reihe dieser Virulenzfaktoren von Plasmidgenen kodiert. Diese Plasmide sind daher wichtiger Bestandteil der genotypischen Ausstattung vieler Bakterien, welche zur effektiven Kolonialisierung des Darms und der Überwindung der Darmschleimhautbarriere fähig sind. Exemplarisch seien hierbei Yersinia outer membrane proteins (Yop) bei Yersinia spp. und das invasion plasmid antigen (Ipa) bei Shigellen erwähnt (vgl. Tabelle 1). Von Bakterien der Gattung Yersinia rufen $Y$. enterocolica und $Y$. pseudotuberculosis gastrointestinale Symptome hervor. Als Yop bezeichnet man eine Reihe von zum Teil von Bakterien sezernierten Virulenzfaktoren, von denen bisher insgesamt 13 verschiedene beschrieben sind und welche via Typ III-Sekretionssystem mit der Wirtszelle interagieren (Cornelis et al. 1998). Yop-Proteine werden von einem 70 kB großen Plasmid der Bakterien kodiert. Dabei funktionieren einige Yops direkt als zytotoxisch wirksame Effektorproteine (z.B. Yop E), welche vom Bakterium in die eukaryonte Wirtszelle transloziert werden, während andere am Translokationsprozess beteiligt sind (Yop B, Yop D), bzw. als 
Regulatorproteine die Yop-Expression steuern (z.B. Yop N). Der Regulation des YopSekretions-Apparats wird wesentlich durch Temperatur und $\mathrm{Ca}^{++}$-Ionen-Konzentration gesteuert (Portnoy et al. 1981). Bakterien der Gattung Shigella sind ebenfalls Auslöser von Durchfallerkrankungen; die Shigellose ist in Entwicklungsländern endemisch. Als wichtiger Pathogenitätsmechanismus der Shigellen wird die Invasion der Kolonmukosa und das Überleben in infizierten Makrophagen des lymphatischen Gewebes des Darms angesehen. Es konnte ein großes Virulenzplasmid isoliert werden, dessen Gene Ipa-Proteine kodieren, welche ebenfalls über ein Typ-III-Sekretionssystem auf die infizierte Wirtszelle übertragen werden können (Buysse et al. 1987). Die Funktion dieser Ipa-Proteine korreliert dabei mit der in-vitro Invasion in Zellkulturen. Dabei ist beispielsweise IpaB in der Lage, in infizierten Makrophagen eine Apoptose auszulösen; Ipa D ist Co-Faktor bei der Lyse der Phagozytenmembran (Hale et al. 1983, Hale et al. 1985).

In aktuellen Untersuchungen konnten immer neue und wichtige Virulenzfaktoren bei Bakterien der Spezies C. jejuni identifiziert werden (Nielsen et al. 2011). In einem Teil der aus Stuhlproben von Durchfall-Patienten isolierten $C$. jejuni-Stämme ließen sich Plasmide unterschiedlicher Größe nachweisen. Dabei besaßen $29 \%$ von 56 isolierten Bakterienstämmen ein oder mehrere Plasmide (Schmidt-Ott et al. 2005). In Anlehnung an die Bedeutung von Plasmiden für die Virulenz anderer darmpathogener Bakterienspezies war es Ziel dieser Arbeit zu klären, ob Plasmide bei $C$. jejuni in analoger Weise für die Kodierung von Virulenzfaktoren essenziell sind. In einem Zellkulturmodel unter Verwendung von humanen intestinalen Caco2-Zellen wurden die Invasions- und Adhärenzeigenschaften von plasmidhaltigen und plasmidfreien $C$. jejuni-Stämmen untersucht.

Die Erzeugung isogener Varianten stellte dabei einen wesentlichen Kernpunkt hinsichtlich der verfolgten Fragestellung dar. Ein einfacher Vergleich von plasmidhaltigen und plasmidfreien klinischen Isolaten liefert aufgrund der unterschiedlichen Ausstattung an chromosomalen Genen nur wenig Aussagen über eine eventuell vorhandene Relevanz von bakteriellen Plasmiden für die Virulenz der Erreger. Daher mussten vorhandene Wildtypstämme zunächst dahingehend modifiziert werden, dass isogene plasmidhaltige und freie Varianten zur Verfügung standen. Als mögliche Lösungsansätze wurden zu Beginn der Arbeit die Plasmidheilung sowie der konjugative Plasmidtransfer gewählt. Der intraexperimentelle Vergleich eines Wildtyp-Stammes mit seiner plasmidfreien (d.h. plasmidgeheilten) Variante bietet dabei wohl die eleganteste Möglichkeit zur Bestimmung der plasmidkodierten Virulenz. Es wurde verschiedene in der Literatur beschriebene Techniken 
benutzt, um eine vollständige Plasmideliminierung zu erreichen (Gellert et al. 1976, Hooper et al. 1984, McHugh und Swartz 1977, Setlow et al. 1984, Wolfson et al. 1983). Obwohl in zahlreichen Versuchsanordnungen eine ganze Reihe von Wildtypstämmen dem Versuch einer Plasmidheilung unterzogen wurden, gelang es nicht, vorhandene Plasmide zu eliminieren. Die Transkonjugation von Antibiotikaresistenzgen-tragenden Plasmiden erwies sich als wertvolle Alternative, um dem ursprünglichen experimentellen Ansatz gerecht zu werden (Taylor et al. 1981). Im Hinblick auf ihr Resistenzprofil und den Besitz von Plasmiden konnten die Stämme A3, A22, A34 als Plasmidrezipienten und A9 und A13 als Plasmiddonoren erfolgreich benutzt werden, um transkonjugierte Varianten zu erzeugen. Die erfolgreiche Übertragung des Plasmids vom Donorstamm auf den Rezipientenstamm konnte dabei durch Plasmidpräparation, sowie durch eine veränderte Antibiotikaresistenz (neu generierte Tetrazyklinresistenz der Konjuganten gegenüber den Wildtypstämmen) gezeigt werden. Eine spontane Mutation der chromosomalen DNA der Rezipientenstämme als Ursache für diesen neuen Phänotyp wurde mit Hilfe einer Pulsfeldgelelektrophorese der betreffenden Stämme ausgeschlossen. Unterschiede hinsichtlich Wachstumsgeschwindigkeit oder Bakterienmorphologie nach Konjugation waren nicht feststellbar.

Als Zellkulturmodell wurden humane intestinale Caco2-Zellen verwendet. Ihre langsame Wachstumsgeschwindigkeit und anspruchsvollen Kulturbedingungen erschweren zwar die Handhabung, jedoch sind sie aufgrund ihrer biologischen Eigenschaften als Zellkulturmodell für Untersuchungen darmpathogener Bakterien gut geeignet: Sie weisen eine strukturelle und funktionelle Polarisierung auf und ähneln in ihrer enzymatischen Ausstattung und ihrer mikrovillösen Besetzung menschlicher Dünndarmmukosa (Everest et al. 1992, Pinto et al. 1983). Um eine vollständige Differenzierung mit Ausbildung von Bürstensaum-Mikrovilli und entsprechenden Enzymmustern und damit eine strukturelle und funktionelle Polarisierung zu erreichen, wurden die Zellkulturen in der postkonfluenten Phase eingesetzt. Damit wurde eine exaktere Annäherung der experimentellen Bedingung an in-vivo Zustände (Dünndarmschleimhaut) geschaffen und dem natürlichen Gewebetropismus der Bakterien stärkere Bedeutung geschenkt. In Anlehnung an Modelle für Zellinvasion, in denen die Wirtszelle einen entscheidenden Aspekt des Invasionsmechanismus bildet (Woodridge et al. 1996, Oelschlaeger et al. 1993), wurde innerhalb der Experimente der Zeitpunkt der Infektion der Caco2-Zellen konstant gehalten (10.-12. postkonfluenter Tag). Um eine mögliche Veränderung der Wirtszellmembran durch chemische Agentien z.B. bei der Zellfixierung vor Immunfluoreszenzmarkierung auszuschließen, wurden zusätzliche Kontrollen nötig. Eine 
mögliche vorzeitige Permeabilisierung durch den Fixationsvorgang konnte hierbei ausgeschlossen werden (vgl. Kapitel 3.4).

Zur Bestimmung der Invasion und Adhärenz von C. jejuni wurden unter Verwendung des invitro Modells zwei verschiedene experimentelle Ansätze etabliert. Im Gentamicin-Protektions Assay (GPA) wird die bakterizide Wirkung von Gentamicin genutzt, um eine Selektion von. intra- und extrazellulären Keimen nach Infektion der Caco2-Zellen zu erreichen. Die Datenerhebung und Auswertung durch Kolonienzählung ist hierbei vergleichsweise schnell durchführbar, sie ist in engen Grenzen unabhängig vom Untersucher (,=Auszähler“). Damit können eine größere Anzahl an gewonnenen Bakterienisolaten - eventuell mit veränderten Fragestellungen und damit abgeänderten Versuchsanordnungen - untersucht werden. Bakterienstämme, die auf diese Weise untersucht werden, können aufgrund ihrer Vitalität nachuntersucht werden (z.B. Plasmidgehalt nach erfolgter Passage, Veränderungen der biologischen Wachstumsaktivität). Bei den mittels GPA getesteten Isolaten A3, A22 und A34, sowie den transkonjugierten Varianten, konnten weder für Adhärenz noch für Invasion signifikante Unterschiede der plasmidhaltigen Varianten gegenüber den Wildtypstämmen nachgewiesen werden. Die Versuche mit A22 und seinen Varianten belegten eine um den Faktor 10 niedrigere Invasionsrate im Vergleich zu den anderen getesteten Stämmen von C. jejuni. Der als Positivkontrolle verwendete Salmonellenstamm zeigte erwartungsgemäß eine deutlich höhere Invasionsrate, die Negativkontrolle (E. coli) dagegen eine deutlich niedrigere Invasionsrate. Somit ließ sich bei $C$. jejuni kein Zusammenhang zwischen Plasmidgehalt und Pathogenität unter den gewählten Bedingungen im GPA nachweisen. Es zeigen sich jedoch Unterschiede zwischen den gewählten Wildtypstämmen, insbesondere eine niedrigere Invasionsrate für A22 und seine Transkonjuganten. Diese Beobachtung weist auf eine Heterogenität hinsichtlich der Pathogenität unterschiedlicher Bakterienisolate hin, die möglicherweise auf chromosomal- kodierte Virulenzfaktoren zurückzuführen ist.

Um die im GPA erzielten Ergebnisse zu bestätigen, wurde als zweite Methode zur Bestimmung von Invasion und Adhärenz im Zellkulturmodell ein indirekter Doppelimmunfluoreszenztest etabliert. Diese Methode ermöglicht eine genauere Bestimmung der invasiven und adhärenten Bakterien durch direkte Darstellung und Quantifizierung der Bakterien zu definierten Zeitpunkten. Verzerrungen des Ergebnisses durch mögliche Beeinflussungen der Replikationsfähigkeit der Bakterien nach Infektion der Caco2-Zellen wurden durch diese Versuchsanordnung ausgeschlossen. Ebenso war es möglich, durch diese Methode die Untersuchung von kurzen Infektionszeiträumen zu realisieren, wie sie bei den 
durchgeführten invasionskinetischen Untersuchungen nötig waren. Zusätzlich zu der quantitativen Bestimmung der invasiven oder adhärenten Bakterien innerhalb einer Versuchsreihe konnten gleichzeitig die verwendeten Stämme in ihrer Morphologie betrachtet und beurteilt werden (Form, Begeißelungsmuster, lokale Verteilungsmuster innerhalb der Zellen). Nach Auswertung aller durchgeführten Versuchsreihen des Immunfluoreszenzversuches (IF-Versuch) ergaben sich sowohl für die getesteten klinischen Patientenisolate, als auch für den Laborstamm NCTC 81-176 mit durchschnittlich 10 invasiven Bakterien sowie 2 adhärenten Bakterien pro 100 Caco2-Zellen keine signifikanten Unterschiede zwischen Wildtypstämmen und transkonjugierten Varianten. Deutlich abweichend davon zeigte sich eine erwartungsgemäß wesentlich höhere Invasionsrate (x10) für den getesteten Salmonella-Stamm mit der etwa zehnfachen Invasionsrate im Vergleich zu C. jejuni. Ebenfalls erwartungsgemäß besaß der als Negativkontrolle verwendete E. coliStamm eine niedrige Invasionsrate von nur 0,5 pro 100 Caco2-Zellen. Die ermittelten Ergebnisse für beide verwendeten Methoden können aufgrund der verschiedenen Auswertungstechniken jedoch nicht direkt miteinander verglichen werden. Während beim GPA absolute Bakterienzahlen bzw. der relative Anteil der invasiven Keime an den zellassoziierten Bakterien bestimmt wurden, beziehen sich die Zahlen für Invasion und Adhärenz im IF-Versuch jeweils auf 100 beurteilte Caco2-Zellen. Die Ergebnisse des zeitlichen Verlaufs der Invasion von $C$. jejuni in Caco2-Zellen zeigten keine signifikanten Unterschiede zwischen plasmidhaltigen und plasmidfreien Stämmen. Die höchsten Invasionsraten wurden jeweils 15min nach Beginn der Infektion bestimmt. Der Wert nach $2 \mathrm{~h}$ entspricht dagegen weitestgehend den Ergebnissen aus den anderen Experimenten mit fixierter Invasionszeit von $2 \mathrm{~h}$. In der Zusammenschau aller relevanten Versuchsergebnisse ist festzuhalten, dass C. jejuni in der Lage ist, Caco2-Wirtszellen zu infizieren. Diese Fähigkeit zu Adhärenz und Invasion gilt als ein bedeutender Virulenzfaktor und wurde bereits in früheren Untersuchungen eingehend gezeigt (Szymanski et al. 1995, Russel und Blake 1994, Hu und Kopecko 1999). Weitere bekannte Virulenzfaktoren von C. jejuni, welche in Zusammenhang mit der Kolonisation des Magen-Darm-Traktes beim Menschen und anderen Säugetieren gebracht werden können, sind die Motilität des Erregers sowie seine Fähigkeit zur Toxinproduktion (Walker et al. 1986). Seit mehr als 20 Jahren ist bekannt, dass Motilität ein wichtiger Virulenzfaktor von C. jejuni ist (Morooka et al. 1985). Es existieren eine Vielzahl von in-vitro und in-vivo Studien, welche eine wesentliche Rolle der Motilität des Erregers für seine Virulenz herausstellen. Untersuchungen an verschiedenen Tiermodellen (z.B. Hamster, Maus) zeigten, dass ein morphologisch und funktionell intaktes Flagellum die 
Voraussetzung für Motilität und der damit verbundenen Kolonisierung des Darmsystems ist (Aguero-Rosenfeld et al. 1990 und Morooka et al. 1985). Untersuchungen von Black et al. 1988 am Menschen zeigten, dass bei Ingestion eines Gemisches von Flagella-positiven und negativen Bakterienkulturen lediglich Flagella-positive Bakterien von den Probanden ausgeschieden wurden, was als eine Selektion zugunsten der Flagella-positiven Keime zu werten ist. Auch in-vitro-Studien unter Verwendung von Caco2-Zellen belegten einen Zusammenhang zwischen Motilität von C. jejuni und der Fähigkeit der Bakterien eukaryonte Zellen erfolgreich zu invadieren (Russel und Blake 1994). Auch neuere Untersuchungen unterstreichen nochmals die herausragende Bedeutung der Motilität des Erregers beim Eindringen in die Wirtszelle. Direkter Einfluss des Flagellarapparates auf den Prozess der Internalisierung konnten jedoch nicht nachgewiesen werden (Novik 2010).

Neben der Motilität ist als weitere Virulenzdeterminante die Produktion von Toxinen (Enterotoxine und Zytotoxine) durch C. jejuni beschrieben (Johnson und Lior 1986). Dabei wirken Enterotoxine über eine intrazelluläre cAMP-Erhöhung und führen zur Flüssigkeitssekretion in das Darmlumen (Prototyp Choleratoxin), während Zytotoxine durch Proteinsynthesehemmung oder Störung der Aktin-Filamente den Zelltod bewirken (Prototyp Shigatoxin). Aufgrund starker regionaler Unterschiede der Stämme hinsichtlich ihrer Fähigkeit zur Enterotoxinproduktion ist die Datenlage diesbezüglich jedoch uneinheitlich. Hohe Prozentsätze an enterotoxinproduzierenden Stämmen konnten beispielsweise in Belgien (Goosens et al. 1985) und in Mexico (Ruiz-Palacios et al. 1983) nachgewiesen werden, wohingegen in Untersuchungen einer anderen Arbeitsgruppe in den USA keine enterotoxinbildenden Stämme nachgewiesen werden konnten (Perez-Perez et al. 1989). Teilweise konnte in Untersuchungen ein Zusammenhang zwischen Enterotoxinproduktion und dem Auftreten der durch wässrige Stühle dominierten Durchfallform gezeigt werden (Florin und Antillon 1992). Auch in Tiermodellen (z.B. Huhn) konnte eine Enterotoxinproduktion nachgewiesen werden (Saha et al. 1988). Die Fähigkeit verschiedener C. jejuni Stämme zur Produktion von Zytotoxinen konnte ebenfalls in verschiedenen Arbeiten der vergangenen Jahre gezeigt werden. Aufgrund von Unterschieden hinsichtlich der jeweils verwendeten Zellkultursysteme, Bakterienstämme und voneinander abweichenden BakterienKulturbedingungen weichen die jeweils gewonnenen Erkenntnisse zum Teil voneinander ab (Wassenaar 1997). Johnson und Lior beschrieben erstmals 1988 das cytolethal-destendingtoxin (CLT), welches bei verschiedenen Zellkultursystemen (CHO, Vero, HeLa und HEp-2) nach 2-4 Tagen Inkubation den Zelltod auslöste (Johnson und Lior 1988). Zellzyklusarrest 
und Apoptoseinduktion der Wirtszellen sind dabei die zugrundeliegenden Mechanismen (Jain et al. 2010).

Während bei der Charakterisierung der oben genannten Virulenzfaktoren in den letzten Jahren Fortschritte erzielt werden konnten, bleibt dagegen die Bedeutung von Plasmiden für die Vermittlung dieser Virulenzdeterminanten weiterhin unklar. Frühere Untersuchungen anderer Arbeitsgruppen zur Bedeutung von plasmid-kodierten Pathogenitätsfaktoren in C. jejuni ergaben zum Teil widersprüchliche Ergebnisse. Tierversuche an schwangeren Meerschweinen konnten keinen plasmidbedingten Virulenzanstieg zeigen (Taylor und Bryner 1984): Bei den entsprechenden Untersuchungen wurde die Abortrate von schwangeren Meerschweinen nach intraperitonealer Bakterieninjektion untersucht. Zur Beurteilung einer darmpathogenen Relevanz von Plasmiden erscheint dieser Versuchsaufbau jedoch ungeeignet. Andere Arbeiten belegen eine plasmidassoziierte Virulenz, allerdings unter Verwendung einer semikonfluenten INT 407-Zellkultur (Bacon et al. 2000, 2002). Der intestinale Ursprung dieser Zellen ist dabei fraglich; vielmehr handelt es sich dabei um eine Subzelllinie der 1951 etablierten HeLa-Zelllinie, welche aus einem hochmalignen Adenokarzinom der Cervix uteri einer 30-jährigen Frau isoliert wurde (Masters 2002). Die Verwendung der INT 407-Zelllinie als geeignetes in-vitro-Modell zum Studium der Pathogenitätsmechanismen eines darmpathogenen Keimes bleibt dabei strittig.

Einer der am besten charakterisierten $C$. jejuni Stämme NTCT 81-176 besitzt zwei Plasmide von jeweils einer Größe von etwa 35kB. Bacon et al. gelang es, einen Zusammenhang zwischen Mutationen in einem der beiden Plasmide (pVir) und einer damit verbundenen Reduktion der Invasions- und Adhärenzraten zu zeigen. Demgegenüber hatte der Verlust des zweiten Plasmids von C. jejuni NCTC 81-176, welches ein Tetrazyklinresistenzgen trägt, keinen Einfluss auf die Invasions und Adhärenzraten des untersuchten Stammes (Bacon et al 2000). Dieses bei Bakterien der Spezies Campylobacter jejuni identifizierte Plasmid (pVir) trägt homologe Gene eines Typ-IV-Sekretionssystems und gab damit weiteren Anlass zu Spekulationen über seine Bedeutung für die Pathogenität des Erregers. In Fortsetzung seiner Versuche wurden mutierte pVir-Plasmide in einen anderen C. jejuni-Stamm (NCTC 11168) transferriert. Die anschließend in einem Gentamicin-Protektions-Assay gemessene Invasion dieses Stammes in INT407-Zellen blieb jedoch trotz nachgewiesenem stabil übertragenem Plasmid auf Wildtypniveau (Bacon et al. 2002). Diese Ergebnisse sprechen gegen eine rein plasmidvermittelte Virulenz und bedürfen einer weiteren kritischen Auseinandersetzung mit dieser Fragestellung. Neuere retrospektive Analysen ließen jedoch 
den Schluss zu, dass das Vorhandensein von pVIR signifikant mit dem Auftreten blutiger Stühle korreliert ist. Jedoch hatten nicht alle mit pVir tragenden Bakterienstämmen infizierte Patienten blutige Stühle- hier liegt der Verdacht nahe, dass weitere Kofaktoren für den klinischen Verlauf verantwortlich zu machen sind. Auch andere klinische Parameter (Fieber, Erbrechen und Hospitalisationsdauer) konnten nicht positiv mit dem Vorhandensein des pVir Plasmids korreliert werden (Tracz et al 2005). Eine ähnlich aufgebaute Studie aus Holland aus dem Folgejahr konnte dagegen keinen Zusammenhang zwischen dem Vorhandensein von pVir und dem Auftreten blutiger Stühle nachweisen (Louwen et al. 2006).

Plamidkodierte Proteine könnten möglicherweise als Co-Faktoren an einem Invasionsvorgang in die Wirtszelle beteiligt sein, innerhalb des gesamten Infektionsvorganges spielen sie jedoch wahrscheinlich nur eine untergeordnete Rolle. Damit sind Pathogenitätsfaktoren hauptsächlich chromosomal kodiert und werden durch plasmidkodierte Faktoren verstärkt. Inwieweit es Zustände der Bakterienzellen (Temperatur, pH-Wert der umgebenden Medien, Wachstumsphase der Bakterien usw.) oder der Wirtszelle gibt, in denen die Beteiligung von plasmidkodierten Bakterienproteinen bei der Zellinvasion an Relevanz deutlich zunimmt, müsste Gegenstand weitergehender Untersuchungen sein.

\section{5.}

\section{ZUSAMMENFASSUNG}

Campylobacter jejuni gilt als eine der wichtigsten Ursachen bakteriell verursachter Durchfallerkrankungen beim Menschen. Aus epidemiologischer Sicht sind Bakterien dieser Spezies die häufigsten nachgewiesenen Erreger bei Durchfallpatienten. Bei einer Vielzahl klinischer Isolate von $C$. jejuni konnten Plasmide in unterschiedlicher Anzahl und Größe nachgewiesen werden.

In der vorliegenden Arbeit sollte daher die Bedeutung von Plasmiden für die Pathogenität von $C$. jejuni näher untersucht werden. Dazu wurden geeignete klinische Isolate von $C$. jejuni aus Stuhlproben isoliert und durch konjugativen Plasmidtransfer verändert, so dass Paare von isogenen Stämmen (Plasmid-positiv / Plasmid-negativ) erzeugt werden konnten. Diese Paare wurden anschließend hinsichtlich Adhäsion und Invasion in einem in-vitro Modell mit humanen intestinalen Caco2- Zellen in einem Zellkulturmodell getestet und miteinander verglichen. Dazu wurden zwei Verfahren, der Gentamicin-Protektions-Assay und die 
indirekte Doppelimmunfluoreszenz, eingesetzt. Die Ergebnisse weisen darauf hin, dass die Anwesenheit eines Plasmids keinen signifikanten Einfluss auf Adhäsion oder/und Invasion in dem von uns gewählten Zellkulturmodell hat. Dies impliziert die Annahme, dass Plasmide von $C$. jejuni keine wesentliche Rolle für die Pathogenität spielen. Diese Erkenntnisse werden zum Teil auch durch Untersuchungen anderer Arbeitsgruppen gestützt. Außerdem kann die Heterogenität der Plasmide von C. jejuni als weiterer Hinweis dafür angesehen werden, dass Virulenzdeterminanten wahrscheinlich eher chromosomal kodiert sind. $\mathrm{Ob}$ dennoch eine partielle Beteiligung plasmidkodierter Virulenzfaktoren am Pathogenitätsgeschehen existiert, muss in weiteren Untersuchungen geklärt werden. 


\section{LITERATURANGABEN}

Aguero-Rosenfeld ME, Yang XH, Nachamkin I (1990): Infection of adult syrian hamsters with flagellar variants of Campylobacter jejuni. Infect Immun 58, 2214-2219

Alshekhlee A, Hussain Z, Sultan B (2008): Guillain-Barré syndrome: incidence and mortality rates in US hospitals. Neurology $\underline{70}, 1608-1613$

Altekruse SF, Stern NJ, Fields PI, Swerdlow DL (1999): Campylobacter jejuni an emerging foodborne disease. Emerg Infect Dis $\underline{5}, 28-35$

Bacon DJ, Alm RA, Burr DH, Hu L, Kopecko DJ, Ewing CP, Trust TJ, Guerry P (2000): Involvement of a plasmid in virulence of Campylobacter jejuni 81-176. Infect Immun $\underline{68}, 4384-4390$

Bacon DJ, Alm RA, Hu L, Hickey TE, Ewing CP, Batchelor RA, Trust TJ, Guerry P (2002): DNA sequence and mutational analyses of the pVir plasmid of Campylobacter jejuni 81-176. Infect Immun $\underline{70}, 6242-6250$

Barth WF, Segal K (1999): Reactive arthritis (Reiters Syndrome). Am Fam Physician 60, 499-507

Black RE, Levine MM, Clements ML, Hughes TP, Blaser MJ (1988): Experimental Campylobacter jejuni infection in humans. J Infect Dis 157, 472-479

Butzler JP, Skirrow MB (1979): Campylobacter-enteritis. J Clin Gastroenterol 모, 737-765 
Buysse JM, Stover CK, Oaks EV, Venkatesan M, Kopecko DJ (1987): Molecular cloning of invasion plasmid antigen (ipa) genes from Shigella flexneri: analysis of ipa gene products and genetic mapping. J Bacteriol 169, 2561-2569

Buzby JC, Allos BM, Robert T (1997): The economic burden of Campylobacter- associated Guillain-Barré Syndrome. J Infect Dis $\underline{176}, 192-197$

Cornelis GR, Boland A, Boyd AP, Geuijen C, Iriarte M, Neyt C, Sory MP, Stainier I (1998): The virulence plasmid of Yersinia, an antihost genome. Microbiol Mol Biol Rev $\underline{62}, 1315-1352$

Ebright JR, Ryan LM (1984): Acute erosive reactive arthritis associated with C. jejuniinduced colitis. Am J Med $\underline{76}, 321-323$

EFSA Panel on Biological Hazards (BIOHAZ) (2011): Scientific Opinion on Campylobacter in broiler meat production: control options and performance objectives and/or targets at different stages of the food chain. EFSA Journal $\underline{9}, 1-2$

Everest PH, Goosens H, Butzler JP, Lloyd D, Knutton S, Ketley JM, Wiliams PH (1992): Differentiated Caco-2 cells as a model for enteric invasion by Campylobacter jejuni und C. coli. J Med Microbiol 37, 319-325

Florin I, Antillon F (1992): Production of enterotoxin and cytotoxin in Campylobacter jejuni strains in Costa Rica. J Med Microbiol 37, 22-29 
Gellert M, O’Dea MH, Itoh T, Tomizawa JI (1976): Novobiocin and coumermycin inhibit DNA supercoiling catalyzed by DNA gyrase. Proc Natl Acad Sci $\underline{73}, 4474-4478$

Goosens H, Butzler JP, Takada Y (1985): Demonstration of cholera-like enterotoxin production by C. jejuni. FEMS Microbiol Lett 29, 73-76

Grifith PL, Park RWA (1990): Campylobacter associated with human diarrhoel disease. J Appl Bacteriol 69, 281-301

Hale TL, Sansonetti PJ, Schad PA, Austin S, Formal SB (1983): Characterization of virulence plasmids and plasmid-associated outer membrane proteins in Shigella flexneri, Shigella sonnei and Escherichia coli. Infect Immun $\underline{40}$, 340-350

Hale TL, Oaks EV, Formal SB (1985): Identification and antigenetic characterization of virulence-associated, plasmid coded proteins of Shigella ssp. and enteroinvasive Escherichia coli. Infect Immun 50, 620-629

Hooper DC, Wolfson JS, McHugh GL, Swartz MD, Tung C, Swartz MN (1984): Elimination of plasmid pMG110 from Escherichia coli by novobiocin and other inhibitors of DNA Gyrase. Antimicrob Agents Chemother 25, 586-590

Hu L, Kopecko DJ (1999): Campylobacter jejuni 81-176 associates with microtubules and dynein during invasion of human intestinal cells. Infect Immun $\underline{67,4171-4182}$

Hueck CJ (1998): Type III protein secretion systems in bacterial pathogens of animals and plants. Microbiol Mol Biol Rev $\underline{62}, 379-433$ 
Jain D, Prasad KN, Sinha S, Vishwakarma AL (2010): Cell cycle arrest \& apoptosis of epithelial cell line by cytolethal distending toxin positive Campylobacter jejuni. Indian J Med Res 129, 418-23

Johnson WM, Lior H (1986): Cytotoxic and cytotonic factors produced by Campylobacter jejuni, Campylobacter coli, and Campylobacter laridis. J Clin Microbiol 24, 275281

Johnson WM, Lior H (1988): A new heat-labile cytolethal destending toxin (CLDT) produced by Campylobacter spp. Microb Pathog $\underline{4}, 115-126$

Kaldor J, Speed BR (1984): Guillain-Barré-Syndrom and Campylobacter jejuni: a serological study. BMJ $\underline{288}, 1867-1868$

Ketley JM (1997): Pathogenesis of enteric infection by Campylobacter. Rev Microbiol 143, 521

Kopecko DJ, Hu L, Zahl KJM (2001): Campylobacter jejuni mikrotubule-dependent invasion. Trends Microbiol 9, 389-396

Louwen RP, van Belkum A, Wagenaar JA, Doorduyn Y, Achterberg R, Endtz HP (2006): Lack of association between the presence of the pVir plasmid and bloody diarrhea in Campylobacter jejuni enteritis. J Clin Microbiol 44, 1867-8

Masters JR (2002): HeLa cells 50 years on: the good the bad and the ugly. Nat Rev Cancer $\underline{2}$, 315-319 
McHugh GL, Swartz MN (1977): Elimination of plasmids from several bacterial species by novobiocin. Antimicrob Agents Chemother 12, 423-426

Morooka T, Umeda A, Amako K (1985): Motility as an intestinal colonization factor for Campylobacter jejuni. J Gen Microbiol 131, 1973-1980

Nachamkin I, Allos BM, Ho T (1998): Campylobacter species and Guillain-Barré-Syndrome. Clin Microbiol Rev 11, 555-567

Netto AB, Taly AB, Kulkarni GB, Umamaheswara Rao GS, Rao S (2011): Mortality in mechanically ventilated patients of Guillain Barré Syndrome. Ann Indian Acad Neurol 14, 262-266

Nielsen LN, Luijkx TA, Vegge CS, Johnsen CK, Nuijten P, Wren BW, Ingmer H, Krogfelt KA (2011): Identification of immunogenic and virulence-associated Campylobacter jejuni proteins. Clin Vaccine Immunol 19,113-119

Novik V, Hofreuter D, Galán J (2010): Identification of Campylobacter jejuni genes involved in its interaction with epithelial Cells. Infect Immun 78: 3540-3553

Oelschlaeger TA, Guerry P, Kopecko D (1993): Unusual microtubule-dependent endocytosis mechanism triggered by Campylobacter jejuni and Citrobacter freundii. Proc Natl Acad Sci USA 90, 6884-6888

Owen RJ, Leaper S (1981): Base composition, size and nucleotide sequence similarities of genome deoxyribonucleic acids from species of the genus Campylobacter. FEMS Microbiol Lett 12, 395-400 
Perez-Perez GI, Cohn RI, Guerrant RI, Patton CM, Reller LB, Blaser MJ (1989): Clinical and immunologic significance of cholera-like toxin and cytotoxin production by Campylobacter species in patients with acute inflammatory diarrhoea in the USA. J Infect Dis $\underline{160}, 460-468$

Pinto M, Robine-Leon S, Appay MD, Kedinger M, Triadou N, Dussaulx E, Lacroix B, Simon-Assmann P, Haffen K, Fogh J (1983): Enterocyte-like differentiation and polarisation of the human colon carcinoma cell line Caco-2 in culture. Biol Cell $\underline{47}$, $323-330$

Pope JE, Krizova A, Garg AX, Thiessen-Philbrook H, Ouimet JM (2007).: Reactive Arthritis: A Systematic Review. Semin Arthritis Rheum 37, 48-55

Poropatich KO, Walker CL, Black RE (2010): Quantifying the association between Campylobacter infection and Guillain-Barré syndrome: a systematic review. J Health Popul Nutr $\underline{28}, 545-52$

Portnoy DA, Moseley SL, Falkow S (1981): Characterization of plasmids and plasmidassociated determinants of Yersinia enterocolitica pathogenesis. Infect Immun $\underline{31}$, 775-782

Rantala H (1991): Occurrence, clinical manifestation and prognosis of Guillain-BarréSyndrome. Arch Dis Child $\underline{66}$, 706-708

Rhodes KM (1982): Guillain-Barré-Syndrome associated with Campylobacter infection. BMJ $\underline{285}, 173-174$ 
Ribot EM, Fitzgerald C, Kubota K, Swaminathan B, Barett TJ (2001): Rapid pulsed-field gelelectrophoresis protocol for subtyping of Campylobacter jejuni. J Clin Microbiol $\underline{39}, 1889-94$

RKI Epidemiologisches Bulletin. Ausgabe 35 S.260, Berlin 1999 (aktualisiert 2005)

RKI Epidemiologisches Bulletin. Ausgabe 36 S.334, Berlin 2007

RKI Infektionsepidemiologisches Jahrbuch meldepflichtiger Krankheiten 2010. S.62-65, Berlin 2011

RKI Gesundheitsberichterstattung des Bundes für das Jahr 2002. S.7 Berlin 2002

Robinson DA (1981): Infective dose of $C$. jejuni in milk. BMJ 282, 1584

Ruiz-Palacios GM, Torres J, Torres NI, Escamilla E, Ruiz-Palacios BR, Tamayo J (1983): Cholera-like enterotoxin produced by Campylobacter jejuni. Lancet ii, 250-253

Russel RG, Blake DC (1994): Cell association and invasion of Caco2 cells by Campylobacter jejuni. Infect Immun $\underline{62}, 3773-3779$

Saha SK, Singh NP, Sanyal SC (1988): Enterotoxigenicity of chicken isolates of Campylobacter jejuni in ligated ileal loops of rats. J Med Microbiol 26, 87-91 
Schmidt-Ott R, Pohl S, Burghard S, Weig M, Groß U (2005): Identification and characterization of a major subgroup of conjugative Campylobacter jejuni plasmids. J Infect $\underline{50}, 12-21$

Setlow JK, Spikes D, Ledbetter M (1984): Loss of plasmids containing cloned inserts coding for novobiocin resistance or novobiocin sensivity in Haemophilus influenzae. J Bacteriol $\underline{158}, 872-877$

Shahrizaila N, Yuki N (2011): Guillain-barré syndrome animal model: the first proof of molecular mimicry in human autoimmune disorder. J Biomed Biotechnol 2011, 1-5

Skirrow MB (1977): Campylobacter enteritis: a „new“ disease. BMJ 2, 9-11

Statistisches Bundesamt: Statistisches Jahrbuch für die Bundesrepublik Deutschland. Wiesbaden 2011

Szymanski CM, King M, Haardt M, Armstrong GD (1995): Campylobacter jejuni motility and invasion of Caco2 cells. Infect Immun $\underline{63}$, 4295-4300

Taylor DE (1992): Genetics of Campylobacter and Helicobacter. Annu Rev Microbiol 46, 3564

Taylor DE, Bryner JH (1984): Plasmid content and pathogenicity of Campylobacter jejuni and Campylobacter coli strains in the pregnant guinea pig model. Am J Vet Res $\underline{45}$, 2201-2202 
Taylor DE, De Grandis SA, Karmali MA, Fleming PC (1981): Transmissible plasmids of $C$. jejuni. Antimicrobial Agents Chemother 19, 831-835

Ternhag A, TörnerA, Svensson Å, Ekdahl, Johan K Giesecke (2008): Short- and Long-term Effects of Bacterial Gastrointestinal Infections. Emerg Infect Dis 14,143-148

Tracz DM, Keelan M, Ahmed-Bentley J, Gibreel A, Kowalewska-Grochowska K, Taylor DE (2005): pVir and bloody diarrhea in Campylobacter jejuni enteritis. Emerg Infect Dis $\underline{11}, 838-43$.

Van Doorn PA, Ruts L, Jacobs BC (2008): Clinical features, pathogenesis, and treatment of Guillain Barré Syndrome. Lancet Neurol 7, 939-950

Vucic S, Kiernan MC, Cornblath DR (2009): Guillain-Barré syndrome: an update. J Clin Neurosci $\underline{16}, 733-741$

Walker RI, Caldwell MB, Lee EC, Guerry P, Trust TJ, Ruis-Palacios GM (1986): Pathophysiology of Campylobacter enteritis. FEMS Microbiol Rev 50, 81-94

Wassenaar T (1997): Toxin production by Campylobacter spp. Clin Microbiol Rev $\underline{10}$, 466476

Wolfson JS, Hooper DC, Swartz MN, Swartz MD, McHugh GL (1983): Novobiocin-induced elimination of $\mathrm{F}^{\prime}$ lac and mini-F plasmids from Escherichia coli. J Bacteriol $\underline{156}$, $1165-1170$ 
Woodridge KG, Wiliams PH, Ketley JM (1996): Host signal transduction and endocytosis of Campylobacter jejuni. Microb Pathog 21, 299-305 


\section{ABBILDUNGEN UND TABELLEN}

Abbildungen

Abbildung 1

Abbildung 2

Abbildung 3

Abbildung 4

Abbildung 5

Abbildung 6

Abbildung 7

Abbildung 8

Abbildung 9
Dem RKI übermittelte Campylobacter-Enteritiden nach Meldewoche im Vergleich mit dem Median der Vorjahre und Anzahl der Erkrankungen in Häufungen nach Meldewoche für Deutschland

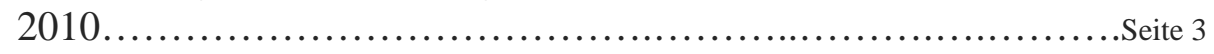

Prinzip der indirekten Doppelimmunfluoreszenz. ..Seite 35

Wachstumskinetik des Wildtypstammes Cj. A22. Seite 37

Wachstumskinetik des Wildtypstammes Cj. A3. Seite 38

Plasmidpräparation der Wildtypstämme und der transkonjugierten Varianten ..Seite 39

Pulsfeldgelelektrophorese mittels des Enzyms Sma-I verdauten chromosomalen Bakterien DNA der Rezipienten (A3, A22, A34), der Donatoren (A9, A13) sowie der Konjuganten (A3pCjA9, A3pCjA13, A22pCjA9, A22pCjA13, A34pCjA9, A34pCjA13)............... Seite 40

PFA-fixierte Zellen nach Behandlung mit anti-dsDNAAntikörpern.................................................

Semilogarithmische Darstellung der Zellassoziationen im GPA..Seite 42

Zellinvasion, dargestellt in halblogarithmischer Form. Seite 43 
Abbildung 10 Invasion und Adhärenz des Wildtypstammes A22 und der beiden transkonjugierten Varianten $\mathrm{A} 22 \mathrm{pCjA} 9$ und $\mathrm{A} 22 \mathrm{pCjA} 13$ im Vergleich................................................ Seite 47

Abbildung 11 Invasion und Adhärenz des Wildtypstammes A34 und der beiden transkonjugierten Varianten $\mathrm{A} 34 \mathrm{pCjA} 9$ und $\mathrm{A} 34 \mathrm{pCjA} 13$ im Vergleich............................................... Seite 48

Abbildung 12 Darstellung von $C$. jejuni mittels indirekter Doppelimmunfluoreszenz. Seite 49

Abbildung 13 Invasion und Adhärenz nach 2h Invasionszeit in der Kontrollgruppe ... Seite 50

Abbildung 14 E. coli DH5 $\alpha$, zellassoziierte Keime, Cy2-markiert. Seite 51

Abbildung 15

E. coli DH5 $\alpha$, extrazelluläre Keime, TRITC-markiert. ..Seite 51 Seite 52

Abbildung 17

Invasion und Adhärenz der Wildtypstämme und ihrer transkonjuganten Varianten im zeitlichen Verlauf. ...Seite 53

$\underline{\text { Tabellen }}$

Tabelle 1

Beispiele für plasmidkodierte Virulenzfaktoren anderer darmpathogener Bakterienspezies. . Seite 7

Tabelle 2

Zusammenstellung der erzeugten transkonjuganten Varianten... Seite 8

Tabelle 3

Antikörpernachweis in Patientenseren. Seite 12 
Tabelle 4

Tabelle 5

Tabelle 6

Tabelle 7

Tabelle 8

Tabelle 9
Antibiotika-Resistenzprofile der verwendeten Wildtyp-Stämme von C..jejuni.................................................. Seite 36

Durchschnittswerte für zellassoziierte, -adhärente und -invasive Bakterien der Wildtypstämme A3, A34, A22 und deren Konjuganten im GPA.................................................... Seite 44

Invasion und Adhärenz von Stamm A34 und seiner Varianten.....Seite 46

Invasion und Adhärenz von Stamm A22 und seiner Varianten...Seite 46

Mittelwerte der Adhärenz- und Invasionsraten zu verschiedenen Zeitpunkten..................................................... 53 


\section{ABKÜRZUNGSVERZEICHNIS}

ATCC

BA

$\mathrm{BE}$

BHI

BSA

C. tetani

CFA

$\mathrm{Cy}$

ddH2O

DMEM

DMSO

DNA

dsDNA

E. coli

EDTA

ELISA

FCS

GBS

GPA

IfSG
American Type Culture Collection

Blutagar

Betriebseinheit

Brain- Heart- Infusion

bovines Serumalbumin

Clostridium tetani

colonization factor antigen

Cyanin

doppelt destilliertes Wasser

Dulbecco’s minimal essential Medium

Dimethylsulfoxid

desoxyribonucleic acid

double- stranded desoxribonucleic acid

Escherichia coli

Ethylendiamintetraessigsäure

enzyme-linked immuno sorbent assay

fetal calf serum

Guillain-Barré-Syndrom

Gentamicin- Protections- Assay

Infektionsschutzgesetz 
$\operatorname{Ig} \mathrm{A}$

Immunglobulin A

IgG

Immunglobulin G

$\operatorname{IgM}$

Immunglobulin $\mathrm{M}$

IPA

invasion plasmid antigen

$\mathrm{kB}$

Kilobasen

$\mathrm{KBE}$

koloniebildende Einheit

Mbp

Megabasenpaare

MEM

Minimum Essential Medium

MFS

Miller- Fisher- Syndrom

MOI

Multiplicity of Infection

Nalres

nalidixinsäureresistent

NCTC

National culture type collection

PBS

phosphate buffered saline

PCR

polymerase chain reaction

PFA

Paraformaldehyd

PFGE

Pulsfeldgelelektrophorese

RKI

Robert-Koch-Institut

RT

Raumtemperatur

SDS

Sodiumdodecylsulfat

ssp

S. Typhimurium

Salmonella Typhimurium

SVP

Salmonella virulence plasmid

TAE

Tris- Acetat- EDTA- Puffer 
Tetres

TRIS

TRITC

ü.N.

vgl.

Yop

ZKF tetracyclinresistent

Trishydroxymethylaminomethan

Tetramethylrhodaminisothiocyanat

über Nacht

vergleiche

yersinia outer membrane proteine

Zellkulturflasche 